\title{
Preliminary Lithostratigraphy, Interpreted Geophysical Logs, and Hydrogeologic Characteristics of the 98th Street Core Hole, Albuquerque, New Mexico
}

By Byron D. Stone', Bruce D. Allen², Marlo Mikolas', John W. Hawley ${ }^{2}$, William C. Haneberg', Peggy S. Johnson ${ }^{3}$, Barry Allred ${ }^{3}$, and Condé R. Thorn ${ }^{4}$

\section{U.S. Geological Survey Open-File Report 98-210}

Prepared in cooperation with the CITY OF ALBUQUERQUE NEW MEXICO OFFICE OF THE STATE ENGINEER NEW MEXICO BUREAU OF MINES AND MINERAL RESOURCES

NATIONAL COOPERATIVE GEOLOGIC MAPPING PROGRAM MINERAL RESOURCES PROGRAM

'U.S. Geological Survey, National Center MS 926-A, Reston, VA 20192

${ }^{2}$ New Mexico Bureau of Mines and Mineral Resources, 2808 Central Ave., Albuquerque, NM 87106

${ }^{3}$ New Mexico Bureau of Mines and Mineral Resources, 801 Leroy Place, Socorro, NM 87801

${ }^{4}$ U.S. Geological Survey, 4501 Indian School Rd., N.E., Suite 200, Albuquerque, NM 87110 


\section{U.S. DEPARTMENT OF THE INTERIOR BRUCE BABBITT, Secretary}

U.S. GEOLOGICAL SURVEY

Thomas J. Casadevall, Acting Director

Copies of this report can be purchased from:

U.S. Geological Survey

Branch of Information Services

Box 25286, Building 810

Denver, CO 80225-0286 


\section{CONTENTS}

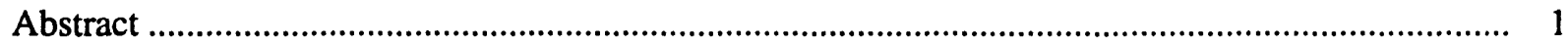

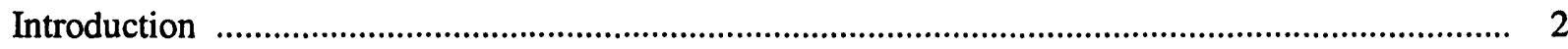

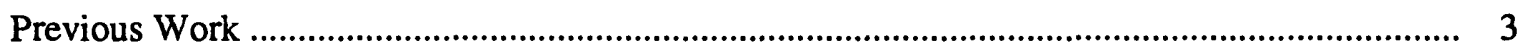

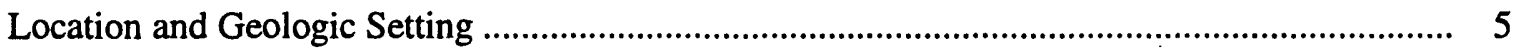

Operations, Recovery, and Well Completion ........................................................................... 5

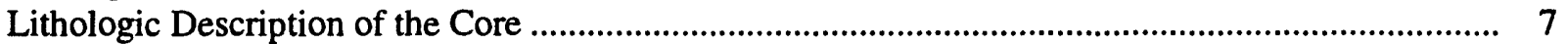

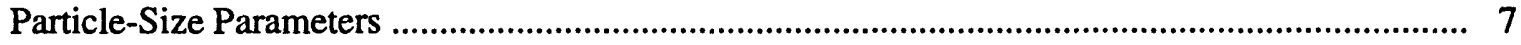

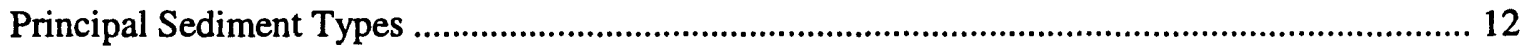

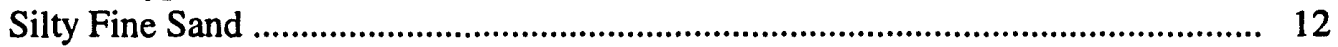

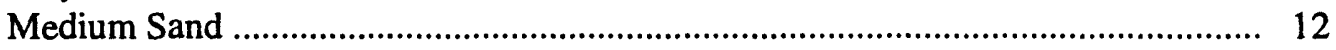

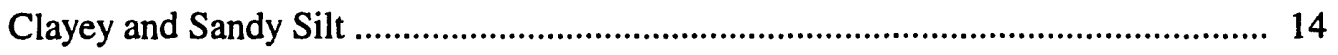

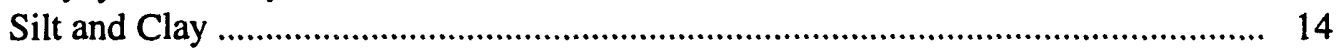

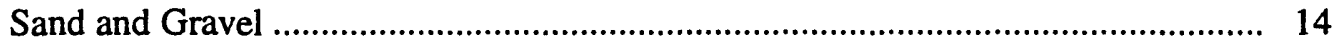

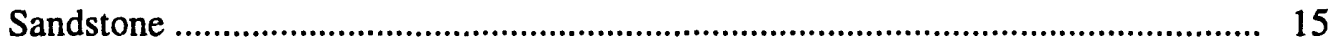

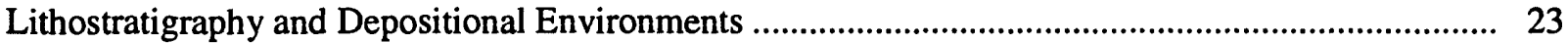

Comparison and Correlation of the 98th Street Well with Nearby Wells ........................................ 25

Estimated Hydrogeologic Characteristics ................................................................................ 29

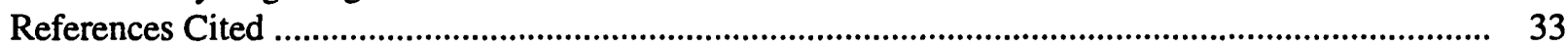

Appendix A. Descriptive lithologic log of the 98 th Street core ...................................................... 37

Appendix B. Detailed geophysical logs for the 98th Street core hole: natural gamma,

caliper, spontaneous potential, conductivity, short and long resistivity, and tension................... 59

Appendix C. Detailed geophysical logs for the 98th Street core hole: natural gamma, caliper,

formation density, and photoelectric absorption.................................................................. 64

Appendix D. Particle-size analyses of channel samples from the 98 th Street core ........................... 69

Appendix E. Hydraulic conductivity of unconsolidated-drained, recompacted sandy samples

from the 98th Street core

\section{FIGURES}

1. Map showing location and geologic setting of 98th Street core-hole site, and locations of

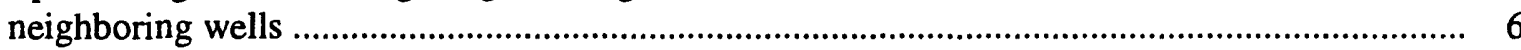

2. Lithologic units and common geophysical logs for the 98th Street core hole ............................ 9

3. Selected geophysical logs and lithologic units of the 98 th Street core hole ................................ 10

4. Cumulative particle-size curves for channel samples from lithologic unit 3 (silty fine sand),

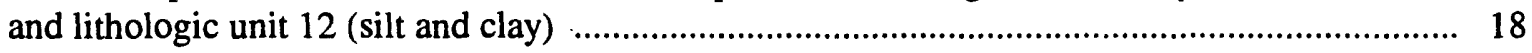

5. Photographs of typical sediment types in the 98 th Street core ................................................ 19

6. Photomicrographs of sandstone in the 98 th Street core ......................................................... 21

7. Preliminary lithostratigraphy and depositional environments of the 98th Street core .................. 27

8. Correlations of the middle Santa Fe Atrisco member (informal) among wells in the College, West Mesa, and Don well fields .................................................................................... 28

9. Hydrogeologic framework of the 98 th Street core ................................................................ 30

\section{TABLES}

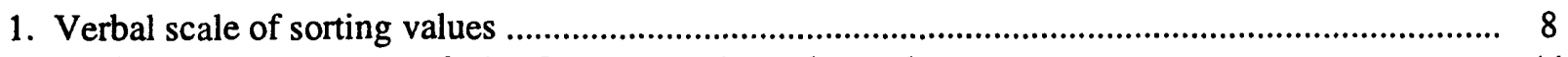

2. Particle-size parameters of 98 th Street core channel samples ................................................ 11

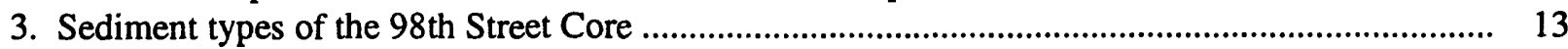


4. Lithologic units and related lithofacies of the 98 th Street core

5. Measured and computed hydraulic conductivity values for samples from the 98th Street core ...... 31

6. Laboratory, empirical, and geophysical hydraulic conductivity values for four samples

from the 98th Street core

CONVERSION FACTORS AND ALTITUDE

\begin{tabular}{lll} 
Multiply & By & To obtain \\
\hline inch & 25.40 & Millimeter \\
foot & 0.3048 & Meter \\
mile & 1.609 & Kilometer \\
$\mathrm{kPa}$ & $1.45 \times 10^{-3}$ & $\mathrm{lbf} / \mathrm{in}^{2}$
\end{tabular}

Altitude in this report is based on the National Geodetic Vertical Datum of 1929 used on 7.5-minute topographic maps in the Albuquerque area.

\section{SYMBOLS AND TERMS}

$\mathrm{CMR}=$ combinable magnetic resonance

$\mathrm{K}=$ average horizontal hydraulic conductivity (ft/day)

$\mathrm{K}_{\mathrm{V}}=$ average vertical hydraulic conductivity ( $\mathrm{ft} /$ day)

$\mathrm{Ohmm}=\mathrm{ohm}$-meter, a unit of resistivity or specific resistance

gAPI = a unit of natural gamma radiation, calibrated in American Petroleum Institute (API) test facilities long-normal resistivity $=\left(\mathrm{ohm}-\right.$ meter $^{2} /$ meter $)$

short-normal resistivity $=\left(\mathrm{ohm}-\right.$ meter $^{2} /$ meter $)$

mmoh $=$ moh-meter, a unit of conductivity

$\mathrm{kPa}=$ kilopascals, a unit of pressure

$\mathrm{psi}=$ pound-force per square inch, $\mathrm{lbf} / \mathrm{in}^{2}$ 


\title{
PRELIMINARY LITHOSTRATIGRAPHY, INTERPRETED GEOPHYSICAL LOGS, AND HYDROGEOLOGIC CHARACTERISTICS OF THE 98TH STREET CORE HOLE, ALBUQUERQUE, NEW MEXICO
}

\author{
By Byron D. Stone, Bruce D. Allen, Marlo Mikolas, John W. Hawley, William C. Haneberg, \\ Peggy S. Johnson, Barry Allred, and Condé R. Thorn
}

\section{ABSTRACT}

Core samples, cuttings, and numerous geophysical logs obtained from the $1560 \mathrm{ft}$ (475.5 m) core hole drilled at 98 th Street on the west side of Albuquerque provide key stratigraphic and hydraulicproperty information for the upper clastic sediments of the Santa Fe Group, which form the principal aquifer in the region. The core hole and an adjacent water-level monitoring well were drilled cooperatively by the U.S. Geological Survey (USGS) and the City of Albuquerque and investigated in collaboration with the New Mexico Bureau of Mines and Mineral Resources and the New Mexico Office of the State Engineer to improve understanding of aquifer characteristics and controls on ground-water availability and quality. The $751.5 \mathrm{ft}(229 \mathrm{~m})$ of core samples recovered from the core hole are the only undisturbed samples of nonlithified sediments of the upper part of the Santa Fe Group that have been collected in this area. These samples have allowed us, for the first time, to directly observe and characterize the lithic and sedimentologic features of this part of the section, and to correlate the detailed geologic features with geophysical-log characteristics, magnetic susceptibility measurements, hydraulic variables, and trace-element geochemistry. The adjacent well was designed to be an areally representative ground-water level and water-quality monitoring well for the Santa Fe Group aquifer. This report chiefly addresses the lithologic, stratigraphic, and hydrogeologic features determined from the 98th Street core hole; other reports address related characteristics.

Previous geologic studies predicted the stratigraphy at the site to be, from the land surface downward: 1) Quaternary alluvial and eolian valley-border sediments; 2) fluvial sand and gravel of the upper unit of the Santa Fe Group (Ceja Member of the Santa Fe
Formation of Kelly, 1978; equivalent to the Sierra Ledrones Formation of Machette (1978a); 3) downward-fining basin-floor silty clay deposits and 4) fluvial sandy and silty facies of the middle unit of the Santa Fe Group (the Middle Red Member of Bryan and McCann, 1937, and Lambert, 1968). New geologic interpretations indicate that the drill site is in a fault block bounded by east-dipping normal faults and the oblique Atrisco-Rincon fault zone.

Core-hole sampling recovered $760.6 \mathrm{ft}(231.8$ $\mathrm{m}$ ) of core, in core segments $2.1-2.375 \mathrm{in}$. $(5.3-6 \mathrm{~cm})$ in diameter, and $0.2-10 \mathrm{ft}(6.1 \mathrm{~cm}-3 \mathrm{~m})$ long. The core hole was cased with centered 3-in. PVC casing, and is available for geophysical logging. The monitoring-well hole contains four piezometers at depths of $1544 \mathrm{ft}(470.6 \mathrm{~m}), 1112 \mathrm{ft}(338.9 \mathrm{~m}), 749 \mathrm{ft}$ $(228.3 \mathrm{~m})$, and $458 \mathrm{ft}(139.6 \mathrm{~m})$.

Sediments in the core are loose to weakly cemented gravel, sand, silt, and clay, and lithified sandstone. Laboratory analyses of particle-size distributions of 28 channel samples show that most silty sand samples are uniformly graded and poorly sorted; medium sand samples are moderately sorted. Six principal sediment types are used to describe the core; these sediment types are repeated in various combinations throughout the core and are used to define 22 lithologic units in the cored interval. The six principal sediment types contain sequences of beds having similar modal grain size and sedimentary structure, and are listed in decreasing abundance:

1) Silty fine sand, poorly sorted, containing a coarse silt matrix. Geophysical logs show highly variable baselines with deflections that are related to clay beds and sequences of silt, clay, and sorted fine sand. Density values of 2.12-2.25 g/cc and porosity values of 30-35 percent are typical.

2) Medium sand, moderately to poorly sorted. Geophysical logs show baselines of low variability with deflections that are related to clay beds and 
sequences of silt, clay, and sorted fine sand. Density values of 2.05-2.20 g/cc and porosity values of 30-35 percent are typical.

3) Clayey sandy silt, poorly sorted, locally microlaminated clay and silt, generally nonplastic. Geophysical logs show highly variable baselines with deflections that are related to sequences of clay and fine sand. Density values of 2.1-2.2 g/cc and porosity values of 30-40 percent are typical.

4) Silt and clay, characteristically red to reddish brown and medium to high plasticity, massive to indistinctly microlaminated. Geophysical logs show variable baselines with broad, high-amplitude compound spikes that are related to sequences of silt and fine sand. Density values of $2.12-2.25 \mathrm{~g} / \mathrm{cc}$ and porosity values of $>45$ percent are typical.

5) Sand and gravel, poorly sorted. Geophysical logs show variable baselines with deflections that are related to sequences of silty and sorted fine sand.

6) Sandstone, fine-to-medium grained, poorly sorted, cemented chiefly by calcite, which fills the original pore space. Geophysical logs show density values $>2.25 \mathrm{~g} / \mathrm{cc}$ and porosity values $<30$ percent.

The 22 lithologic units are correlated with recognized basin-floor fluvial lithofacies (Hawley, 1996), which include sand and gravel (lithofacies I), sand with lenses of pebbly sand, silt, and silty clay (lithofacies II), and interbedded sand, silt, and silty clay (modified lithofacies III, IV, IX).

The sediments in the core hole are correlated with three informal lithostratigraphic units. The top unit, 0-19 $\mathrm{ft}$ (0-5.8 m) depth, consists of Quaternary eolian sand and valley-border alluvium. Coarsegrained deposits in the 19-97 ft (5.8-29.6 m) interval are correlated with the upper unit of the Santa $\mathrm{Fe}$ Group. The fine-grained section in the $97-787 \mathrm{ft}$ (29.6-239.9 m) interval is correlated tentatively with the middle unit of the Santa Fe Group. This section contains thick sequences of laminated red and olivebrown clay and silt overbank deposits (441-787 ft) in the distinctive Atrisco member of Connell and others (1998). The Atrisco is correlated with fine-grained zones in numerous wells throughout the central Albuquerque metropolitan area, and is recognized as a zone that separates the upper Santa Fe aquifer from underlying middle Santa Fe deposits. The lower section of the middle unit of the Santa Fe, $787-1500 \mathrm{ft}$ (239.9-457.2 m) depth, includes an upper sequence of moderately sorted channel-fill medium sand, and a lower sequence of sand, silt, and clay overbank deposits. The age of the cored interval is not known precisely. The upper Santa Fe gravel is related regionally to a through-flowing river system that was established in the Rio Grande rift valleys in Early Pliocene time, $\geq 4.5 \mathrm{MA}$. The middle Santa Fe unit is dated tentatively by correlation with a fossiliferous section, in which sandy beds that directly underlie the upper Santa Fe are Late Miocene (Hemphellian), 4.68.9 MA. Further, the middle Santa Fe unit, with dominantly normal magnetic polarity, may have been deposited during closely spaced normal magnetic chrons 5.9-8.3 Ma.

Four hydrostratigraphic units summarize the hydrogeologic framework for the 98th Street site:

1) Quaternary valley-border deposits, 2) upper Santa Fe sand and gravel deposits, 3) middle Santa Fe overbank deposits, and 4) middle Santa Fe channel-sand deposits. Empirical values of horizontal hydraulic conductivity estimated from core samples reveal a previously unknown contrast in hydraulic conductivity in the lowest two hydrostratigraphic units. Correlations among numerous wells show that the distinctively fine-grained Atrisco member, with estimated hydraulic conductivities $(\mathrm{K})$ of $<0.02-17$ $\mathrm{ft} /$ day, is a laterally extensive barrier to vertical ground-water flow. The underlying unit that contains moderately sorted medium sand is a potential aquifer production zone that should be investigated further.

Laboratory determination of vertical hydraulic conductivity values for fine-grained core samples range from $10^{-2}$ to $10^{-7} \mathrm{ft} /$ day; recompacted sandy samples have $\mathrm{K}$ values of 1 to $10^{-2} \mathrm{ft} /$ day. Results of tests conducted with increasing effective stress show that $K$ values of all samples decrease with decreasing porosity. Comparison of $\mathrm{K}$ values from laboratory, empirical, and calculated geophysical values shows discrepancies of 1-3 orders of magnitude ( $\mathrm{ft} /$ day), indicating that additional analyses of core samples and geophysical data are necessary for future characterization of the Santa Fe Group aquifer.

\section{INTRODUCTION}

The U.S. Geological Survey (USGS) and the City of Albuquerque drilled a stratigraphic core hole to a total depth of $1560 \mathrm{ft}$ (475.4 m) into Santa Fe 
Group deposits on the west side of Albuquerque from September through November, 1996 (Stone and others, 1997, Stone and Allen, 1998). The core hole is located $3.5 \mathrm{mi}(5.6 \mathrm{~km})$ west of the Rio Grande, $0.49 \mathrm{mi}(0.77 \mathrm{~km})$ north of Interstate Route 40 , on the east side of 98 th Street (fig. 1). The New Mexico Bureau of Mines and Mineral Resources and the New Mexico Office of the State Engineer collaborated in investigations of the core hole and an adjacent ground-water monitoring well in order to improve understanding of aquifer characteristics and controls on ground-water availability and quality. The drilling project was completed as part of the ongoing cooperative Middle Rio Grande Basin Study, early results of which are reported in Bartolino (1997) and Slate (1998).

The core hole was located at 98th Street in order to: 1) provide core samples of typical nonlithified and lithified sediments of the upper part of the Santa Fe Group, 2) characterize the hydrogeologic properties of sediments in the area, previously inferred from geologic studies (Hawley and Haase, 1992, Hawley, 1996) and the ground-water model of Kernodle and others (1995), and 3) determine corehole stratigraphy to be calibrated with geophysical logging tools commonly used in studies of the Middle Rio Grande aquifer. The core-hole site is within 1.2-1.9 $\mathrm{mi} \mathrm{(2-3} \mathrm{km)} \mathrm{of} \mathrm{the} \mathrm{Don} \mathrm{1,} \mathrm{West} \mathrm{Mesa} 1$ and 2, and College 1 and 2 Albuquerque municipal wells, all of which produce water with elevated values of arsenic. For example, arsenic values are as high as 50 $\mathrm{ppb}$ in the Don 1 well. The ground-water monitoring well at the 98th Street site, drilled to a total depth of $1547 \mathrm{ft}(471.5 \mathrm{~m})$, contains four nested piezometers. Thus, the site also provides: 4) sediment and water samples for analysis of arsenic species and determination of the origin of subsurface arsenic, and 5) an areally representative ground-water monitoring well $>1 \mathrm{mi}(1.6 \mathrm{~km})$ distant from presently producing municipal wells.

The purpose of this report is to provide a preliminary description of the lithologic and stratigraphic features of the 98th Street site using field descriptions of the core samples and references to geophysical logs commonly used in analysis of well data in the Middle Rio Grande basin. The report includes laboratory analyses of particle size and hydraulic conductivity for representative channel samples, as well as description of the geologic setting, correlations with nearby wells, and preliminary estimates of hydrogeologic characteristics of hydrostratigraphic units. Separate reports present preliminary data concerning the occurrence of arsenic in the sediments from the 98th Street site (Stanton and others, 1998), preliminary magnetic characteristics of the core (Hudson and others, 1998), particle-size and hydraulic conductivity measurements of core samples (Haneberg and others, 1998a), and measure-ments of stress-dependent hydraulic conductivity of the Santa Fe Group aquifer (Haneberg and others, 1998b).

\section{Acknowledgments}

The authors commend the expertise of the USGS drilling team, Dan Sweeney, Steve Grant, Brian Bretz, Art Clark, and Don Queen, consultant, who devised strategies to deliver undisturbed core samples on schedule, and who completed the monitoring well in challenging conditions. Priscilla Gomez and Amy Gibson completed particle-size and hydraulic conductivity analyses of the samples (Haneberg and others, 1998b). In visits to the drill site, the following scientists contributed collegial discussions of Santa Fe Group stratigraphy, tectonic history of the Albuquerque Basin, and detailed geologic features of the 98th Street area: D.W. Sawyer, S.D. Connell, C.R. Menges, S.D. Personius, R.R. Shroba, and A.J. Kuhle. Doug Earp, City of Albuquerque, helped locate the holes to address the arsenic problem. Frank Titus, N.M.O.S.E. provided insights into the regional hydrogeologic setting. The manuscript benefitted from thoughtful reviews by J.M. Cole, R.W. Harrison, and M.R. Stanton.

\section{Previous Work}

Reconnaissance mapping of upper Santa Fe Group basin-fill deposits and definition of stratigraphic units in the Rio Grande valley area that includes the 98th Street drill site were originally presented by Bryan (1909, 1938), Lambert (1968), and Kelley (1977). Bjorklund and Maxwell (1961), Lambert (1968), and Kaehler (1991) also developed preliminary conceptual models of subsurface hydrogeologic conditions in the area, and constructed schematic cross sections based on available waterwell data. Spiegel and Baldwin (1963) formally 
proposed raising the Santa Fe Formation (Bryan, 1938) to group status; and Spiegel (1961) first documented the presence of axial fluvial deposits of the ancestral Rio Grande system in both middle and upper parts of the Santa Fe Group in the northern Albuquerque Basin. Basin-fill deposits were included in the middle and upper parts of the Santa Fe Group (Formation) by Lambert (1968) and Kelley (1977), following the (informal) Lower gray, Middle red, and Upper buff lithostratigraphic classification system originally proposed by Bryan and McCann (1937).

Previous mapping in the west valley-border area including the 98th Street drill site, and study of drilling records from the nearby West Mesa No. 1 City well revealed that thin Quaternary alluvial and eolian valley-fill sediments are underlain by a thick sequence of coarse-to-fine-grained fluvial deposits of the Upper buff to Middle red units of the Santa Fe (Lambert, 1968). Kelley (1977) mapped the surface basin-fill deposits in area as the Ceja Member of the Santa Fe Formation. He characterized the Ceja as a buff-colored sandy unit containing scattered beds of pebble to cobble gravel and a basal gravel zone (pebbly conglomerate) (Kelley, 1977, p. 20). At its type locality at the west edge of the Llano de Alburquerque $6 \mathrm{mi}(9.7 \mathrm{~km})$ west of the $98 \mathrm{th}$ Street site, the Ceja member is $211 \mathrm{ft}(64.3 \mathrm{~m})$ thick. Lozinsky $(1988,1994)$ and Lozinsky and others (1991) further described the two-part stratigraphy (piedmont-slope and basin-floor lithofacies) of the upper and middle Santa Fe in the northern Albuquerque Basin primarily from subsurface and sedimentary petrologic perspectives. They emphasized that fluvial sediments of the upper Santa Fe Group were deposited by perennial tributaries of the ancestral river system that headed in Rio Grande rift basins of the southern Rocky Mountain province and adjacent parts of the Colorado Plateau.

Recent subsurface hydrogeologic work in the northern Albuquerque Basin has been reviewed by Hawley and others (1995). They include the Ceja Member and the Sierra Ladrones Formation of Machette (1978a) in the upper Santa Fe hydrostratigraphic unit, and correlate the unnamed middle Santa Fe unit with parts of the Cochiti and Popotosa Formations mapped by Manley (1978), Machette (1978a, b), and Lozinsky and Tedford (1991) in the northern and southern parts of the Basin, respectively.
Lozinsky and Hawley (1992, p. II-5) and Hawley and others (1995, p. 47) also emphasized the transitional nature of ancestral Rio Grande fluvial deposits between Middle and Upper Santa Fe units in the northern Albuquerque Basin. They further described a series of mappable lithofacies within the Santa Fe, which are recognized by grain size, mineral composition, body geometry, and inferred environments of deposition. The lithofacies classification includes coarse-grained, gravelly and sandy facies (I, II, VII, VIII) and finer grained sandy to clayey facies (III, IV, $\mathrm{IX}, \mathrm{X})$ of the basin floor, and mixed coarse and finegrained facies $(\mathrm{V}, \mathrm{VI})$ from piedmont areas. In the 98th Street area, basin-floor fluvial lithofacies comprising sand and gravel (lithofacies I), sand with lenses of pebbly sand, silt, and silty clay (lithofacies II), and interbedded sand, silt, and silty clay (modified lithofacies III, IV, IX) are dominant in the upper and middle Santa Fe units (Hawley and Haase, 1992, Plate 3; Hawley, 1996, Plate 7).

For purposes of conceptual models of the basin hydrogeologic framework, Hawley and Haase (1992) proposed informal hydrostratigraphic subdivisions of the Santa Fe Group which broadly correspond to the upper (Sierra Ladrones-Ceja), unnamed middle (red), and lower (Zia) formational units of Lozinsky and Hawley (1992). In the 98th Street area, the upper Santa Fe hydrostratigraphic unit originally included coarse fluvial deposits of the ancestral Rio Grande and Rio Puerco systems, and an underlying unit of interbedded fine-grained sediments deposited in the structural depression between the Rio Grande and the County Dump fault (Hawley and Haase, 1992, Plate 3). The upper Santa Fe, inferred to be $900-1200 \mathrm{ft}$ thick, overlies the middle Santa Fe hydrostratigraphic unit ( $>5000 \mathrm{ft}$ thick) comprising sandy to fine-grained basin-floor sediments. Hawley (1996) subsequently placed the fine-grained beds previously correlated with the lower part of the upper Santa Fe in the transition zone at the top of the middle Santa Fe hydrostratigraphic unit. This reinterpretation was based on new analyses of subsurface information that greatly expanded the data base of geophysical logs, well cuttings, cores, and subsurface extent of hydrostratigraphic units available to Haase (1992), Lozinsky $(1988,1994)$, and Mozley and others (1992).

In summary, prior to completion of the 98th 
Street core hole, the subsurface geology in the area was predicted to include, from top down: 1) Quaternary surficial alluvial and eolian sediments, 2) fluvial sand and gravel facies of the upper Santa Fe Group, 3) downward fining basin-floor fluvial and possible playa-lake silty clay facies of a transition zone within the middle Santa Fe Group, 4) fluvial sandy and silty facies of the middle Santa Fe Group, possibly more consolidated and cemented than overlying strata. In addition, interpretations of high-amplitude anomalies in gamma and conductivity logs for other wells could not confirm or distinguish among clay of fluvial or playa-lake origin, or stratigraphically significant volcanic-ash strata. The ground-water flow model of Kernodle and others (1995) incorporated the previous interpretation of the subsurface geology, assigning mean hydraulic conductivity values of $15 \mathrm{ft} /$ day in the upper $570 \mathrm{ft}$ of the saturated zone of the aquifer (378$948 \mathrm{ft}$ [115.2-288.9 m] depth in the monitoring well), and $4 \mathrm{ft} /$ day in the lower $550 \mathrm{ft}(948-1498 \mathrm{ft}$ [288.9$456.6 \mathrm{~m}$ ] depth)

\section{Location And Geologic Setting}

The 98th Street core hole is located $3.5 \mathrm{mi}$ $(5.6 \mathrm{~km})$ west of the Rio Grande, $0.49 \mathrm{mi}(0.77 \mathrm{~km})$ north of Interstate Route 40, on the east side of 98th Street (35'5'32"N, $106^{\circ} 44^{\prime} 52^{\prime \prime} \mathrm{W}$, fig. 1). The corehole site is in the highway right-of-way managed by the New Mexico Highway and Transportation Department, District 3 Office, which granted permission for location of the core hole and monitoring well. The site is at an altitude of $5320 \mathrm{ft} 1621.5 \mathrm{~m}), 400-450 \mathrm{ft}$ (122-137 m) below the Llano de Alburquerque geomorphic surface to the west, in a small valley cut into Santa Fe deposits $2.6 \mathrm{mi}(4.3 \mathrm{~km})$ south of the Albuquerque volcanic field (fig. 1). The valley drains eastward where it converges with the surface of Quaternary fluvial terrace deposits of the inner Rio Grande valley.

The 98th Street site is located on the west side of a regional gravity-low anomaly (Heywood, 1992), which is inferred to reflect mostly thickening of the Santa Fe deposits in the Central Albuquerque basin of Hawley (1996). The drill site is in a fault block bounded by east-dipping, intrabasin normal faults (fig 1), traces of which appear as continuous linear anomalies in high-resolution aeromagnetic data
(Grauch, 1998). At the surface, the western fault is expressed by linearly aligned erosional remnants of the Santa Fe Group. The vertical offset of the eastern bounding fault is inferred from stratigraphic correlations among wells in the College and West Mesa well fields (discussed below). Strata in the core-site fault block are inferred to be subhorizontal or to dip $<10^{\circ}$ to the west, in accordance with minor rotation of the fault block. To the south, the corehole fault block is bounded south of Interstate Route 40 by the Atrisco-Rincon fault zone, an oblique transverse zone that is located at the southern ends of the north-south-trending intrabasin normal faults (Hawley, 1996).

\section{Operations, Recovery, and Well Completion}

The 98th Street core hole was drilled to a total depth of $1560 \mathrm{ft}$ (475.4 m) with a mud-rotary drill, employing a wire-line inner-barrel core-recovery system. Dan Sweeney (USGS) was driller in charge of operations, assisted by Steve Grant, Bryan Bretz, and Art Clark. Drilling began on September 21, 1996, when the first core samples were recovered below the 25-ft long surface casing. Drilling and sampling continued through November 12 when the base of the coring interval was reached at $1500 \mathrm{ft}(457.2 \mathrm{~m})$ depth. A total of 230 coring drives were completed in $1496.4 \mathrm{ft}(456.1 \mathrm{~m})$.

Wire-line coring operations were attempted in each drive; however, core samples were discontinuous due to changing subsurface conditions, drilling speed, and time constraints of the drilling schedule.

Sampling recovered $751.5 \mathrm{ft}(229 \mathrm{~m})$ of core, about 50 percent of the coring interval, and 48 percent of the total depth of the hole. The recovery rate was 52 percent of the actual intervals in which coring was attempted. Core samples are in segments that vary in diameter from 2.1 in. to 2.375 in. $(5.3 \mathrm{~cm}$ to $6.0 \mathrm{~cm})$, and in length from $0.2 \mathrm{ft}$ to $10 \mathrm{ft}(6 \mathrm{~cm}$ to $3.05 \mathrm{~m})$. Sampled intervals were distributed evenly over the total drilled depth (fig. 2). Core samples recovered most sediment types, excluding loose cobbles which were not retrieved, and loose sand which was selectively lost due to hydraulic erosion by drilling fluids in front of the drill bit. Other core-retrieval problems included thin lithified zones that became lodged in the 
core barrel during continuous coring, and plastic clay zones that did not break loose during retrieval. The core hole was deepened to $1560 \mathrm{ft}(473 \mathrm{~m})$ to accommodate geophysical logging tools.

A second hole for the 98 th Street monitoring well was drilled $60 \mathrm{ft}(18 \mathrm{~m})$ north of the core hole, beginning on November 21,1996 . Core samples were obtained from 122-132.7 ft (37.2-40.4 m), 253$260.7 \mathrm{ft}$ (77.1-79.5 m), and 314-322.5 ft (95.7-98.3 $\mathrm{m}$ ) intervals. Ground-water sampling to evaluate arsenic values was attempted at $720 \mathrm{ft}(219.4 \mathrm{~m})$, but incomplete packing of the well screen and poor production from the silty sand strata prevented collection of representative samples. Freezingweather conditions and resultant equipment problems delayed drilling completion of the second hole to a total depth of 1,547 ft (471.5 m) until February 3, 1997.

The core hole was cased with 3-in. PVC (polyvinyl chloride) casing, using centralizers every $40 \mathrm{ft}(12.2 \mathrm{~m})$, to a depth of $1,435 \mathrm{ft}(437.4 \mathrm{~m})$. The hole was filled with abandonment mud around the PVC casing. The hole was sealed with cement from the bottom upward to $1,320 \mathrm{ft}$ (402.3 m) depth. The completed hole is available as a geophysical logging reference hole through arrangements with the U.S. Geological Survey, Albuquerque.

The monitoring-well hole was reamed to 12.25 in. $(31.1 \mathrm{~cm})$ diameter, and four PVC piezometers were installed and screened at depth intervals of 1,534-1,539 ft (467.5-469.1 m), 1,102$1107 \mathrm{ft}(335.9-337.4 \mathrm{~m}), 739-744 \mathrm{ft}(225.2-226.8 \mathrm{~m})$, and $388-433 \mathrm{ft}$ (118.2-132.0 m), completed on February 9, 1997. The uppermost piezometer is screened for $45 \mathrm{ft}$ (12.2-24.4 $\mathrm{m})$ at a depth beginning $10 \mathrm{ft}(3 \mathrm{~m})$ below the water table at $378 \mathrm{ft}(115.2 \mathrm{~m})$. The intermediate and two deepest piezometers were completed with 5 - $\mathrm{ft}$ screens in the more permeable zones of the middle and bottom parts of production zones in the area, based on elevations of screened intervals from nearby production wells (fig.1) projected to the 98 th Street site. The piezometer at $749 \mathrm{ft}(228.3 \mathrm{~m})$ depth was completed in order to sample water in a distinctive olive-colored silt-clay zone. Each piezometer is instrumented with a pressure transducer in order to obtain continuous measurements of hydraulic head. Water-quality samples will be collected from each piezometer annually or biannually as part of the areal monitoringwell network (Thorn, 1997).

\section{LITHOLOGIC DESCRIPTION OF THE CORE}

Lithologic units and common geophysical logs for the 98th Street core hole are shown in figure 2; additional geophysical logs that correlate with lithologic properties are shown in figure 3. Sediments in the core generally are compacted, stratified, loose to very weakly cemented sand, silt, clay, and gravel, and cemented sandstone (figs. 5, 6), in decreasing order of abundance. In the field, twenty-two sediment types, distinguished by their lithologic characteristics including color, particle size, sorting, sedimentary structure, and mineralogy, were used to describe individual beds or sets of similar beds in the core (see core description, Appendix A). Color values were estimated for naturally moist samples by visual comparison with standard color charts (Munsell, 1975). Basal contacts of strata generally are distinct and planar. Stratification in all parts of the core appears to be horizontal. The core samples are characterized by loose to very friable consistence for sand, and firm consistence for clay and silty clay (ASTM, 1995). For the purposes of this report, the 22 descriptive sediment types are grouped into six principal sediment types (table 1) that contain interbedded sets of beds with similar modal grain size and sedimentary structure. These six sediment types are repetitive in the cored interval (fig. 2), and are used to depict the vertical sequence of lithologic units (fig.2).

\section{Particle-Size Parameters}

Descriptions of the beds in the core samples include estimated particle-size (grain-size) parameters, which use the geologic particle-size classification that is based on the phi scale, in which:

$$
\text { phi }=-\log _{2}[\text { diameter, } \mathrm{mm}]
$$

Particle-size modal class and range in phi units (fig. 4) were estimated by visual comparison with a grain-size card that displays grain sizes in half-phi intervals.

Sorting descriptions are based on the graphic standard deviation, $\sigma_{G}$, method of Folk (1980), which employs the estimated particle-diameter ratios of the 16th and 


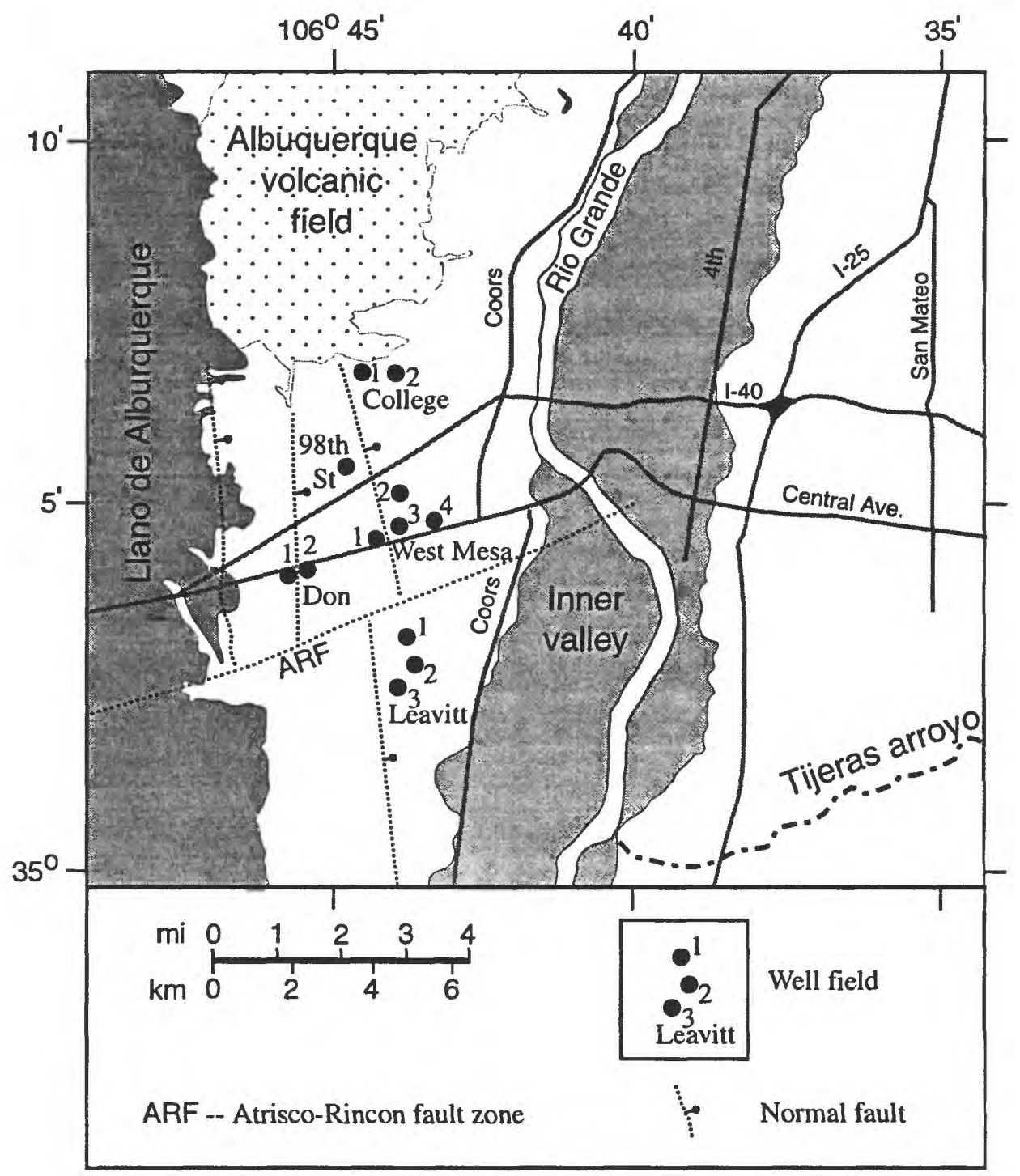

Figure 1. Location and geologic setting of the 98th Street core-hole site, and locations of neighboring wells. 
Elevation Depth Conductivity Natural gamma

(ft) $\mathrm{ft}$
(5320) 0

(5200)

$$
\text { (510 }
$$

(5000)

$(4900$

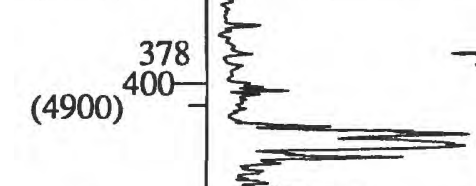

(4800)
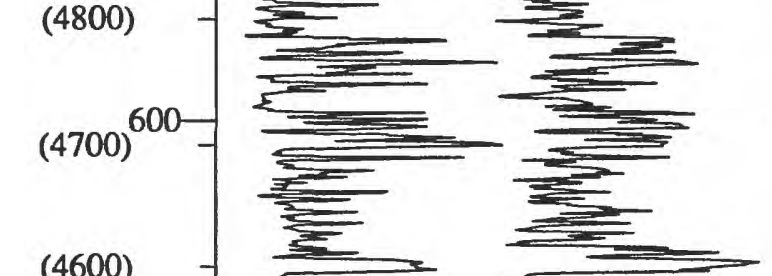

(4600)
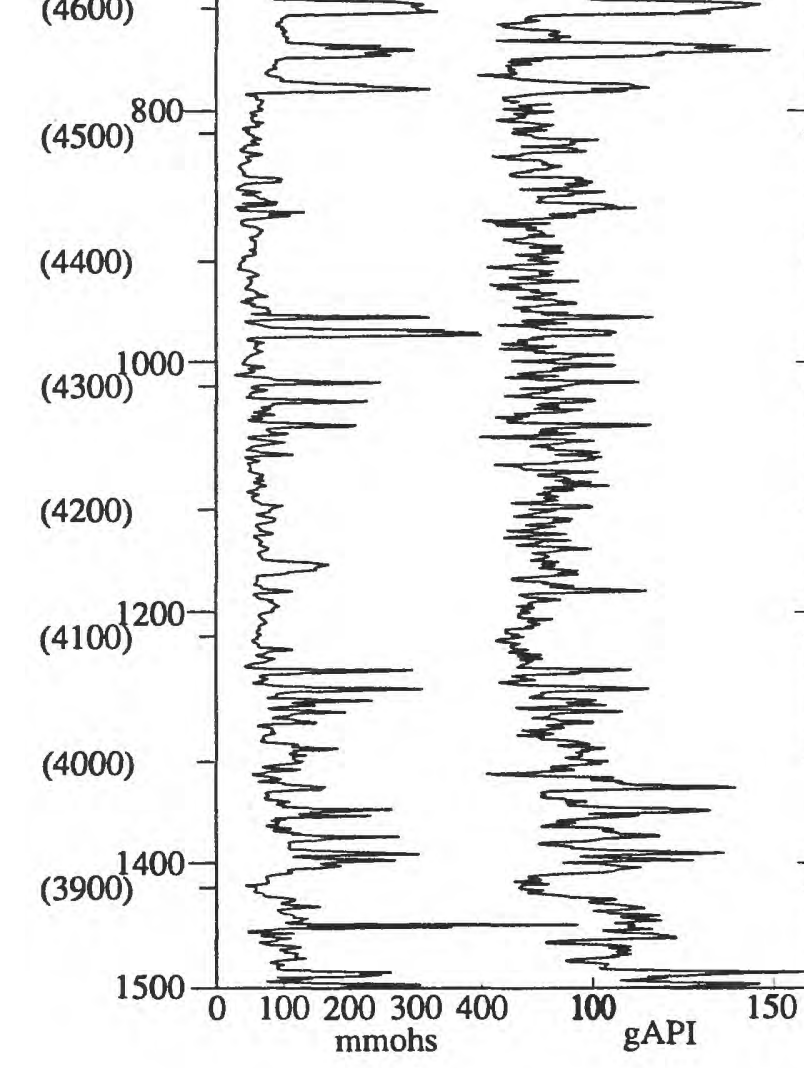

Sample Lithologic Lithofacies intervals unit (Hawley, 1996) 
84th percentile of the particle-size distribution:

$$
\sigma_{G}=\frac{\phi 84-\phi 16}{2}
$$

in which the standard deviation is a measure of the spread in phi units of the sample. A verbal classification scale of sorting values derived from the graphic standard deviation, or from the ratio, in millimeters, of the $D_{16}$ and $D_{84}$ values is given in table 1 .

Estimates of $D_{16}$ and $D_{84}$ were based on visually estimated particle diameters, consistent with the total range of particle sizes. Estimates of $D_{10}$, the grain size of the 10th percentile at the finer end of the grain-size distribution, are based on visually estimated particle diameters (fig. 4).

Laboratory analyses of grain-size distributions were conducted on 28 channel samples (Haneberg and others, 1998b), which integrate the grain-size distributions of multiple beds in the sampling intervals. One sample was taken from the total core samples from each of twenty lithologic units (fig. 2) in the 19-1496.4 $\mathrm{ft}(5.8-456.1 \mathrm{~m})$ interval. Eight channel samples from core lengths of $1.4 \mathrm{ft}$ to $2 \mathrm{ft}$ (0.4-0.6 m) (Appendix D) were taken from the top 97 $336 \mathrm{ft}$ (29.6-102.4 m) of the cored interval. Particlesize parameters of all the core samples are based on the engineering methods (mechanical sieving of sand particles $\geq 0.075 \mathrm{~mm}$ diameter; hydrometer analysis of silt and clay particles $<0.075 \mathrm{~mm}$ ) and classification system that employ selected sieve intervals for mechanical analysis (Appendix D).

Sample gradation was determined after calculating the coefficient of curvature, $\mathbf{C}_{\mathrm{c}}$, and the coefficient of uniformity, $\mathbf{C}_{\mathrm{u}}$. Equations for both coefficients are as follows:

$$
\begin{aligned}
& C_{c}=\frac{\left(D_{30}\right)^{2}}{\left.\left(D_{10}\right) D_{60}\right)} \text {, and } \\
& C u=\frac{D_{60}}{D_{10}}
\end{aligned}
$$

where $D_{10}, D_{30}$, and $D_{60}$ are the grain diameters at 10 , 30 , and 60 percent (finer) passing. A sandy sample is considered well graded if:

$$
\begin{aligned}
& 1 \leq C_{C} \leq 3 \text {, and } \\
& C_{u} \geq 6
\end{aligned}
$$

If either of these conditions do not hold, then the sample is said to be poorly graded or uniformly graded (Appendix D).

Table 3 shows the estimated and measured particle-size parameters for the core channel samples. The estimated values for modal size and sorting are based on estimates of the predominant sediment type in each sample interval (as in fig. 2, and table 1). All of the samples are coarse-grained $(<50$ percent fine particles passing the number 200 sieve $[0.075 \mathrm{~mm}]$ ), but most contain 5-12 percent fine particles and are thus classified using both coarse- and fine-soil descriptions. In general, the laboratory analyses support the estimated parameters for sediment types, such as modal size class and degree of sorting. Note

Table 1. Verbal scale of sorting values (modified from Folk, 1980)

$\begin{array}{lll}\begin{array}{l}\mathrm{D}_{16} / \mathrm{D}_{84}, \mathrm{~mm} \\ \text { Diameter ratio }\end{array} & \begin{array}{c}\text { phi standard } \\ \text { Deviation }\end{array} & \text { Verbal scale } \\ 1.0 & 0.00 & \\ 1.6 & 0.35 & \text { Very well sorted } \\ 2.0 & 0.50 & \text { Well sorted } \\ 4.0 & 1.00 & \text { Moderately sorted } \\ 8.0 & 1.50 & \text { Poorly sorted } \\ 16.0 & 2.0 & \\ & & \text { Very poorly sorted }\end{array}$


妾

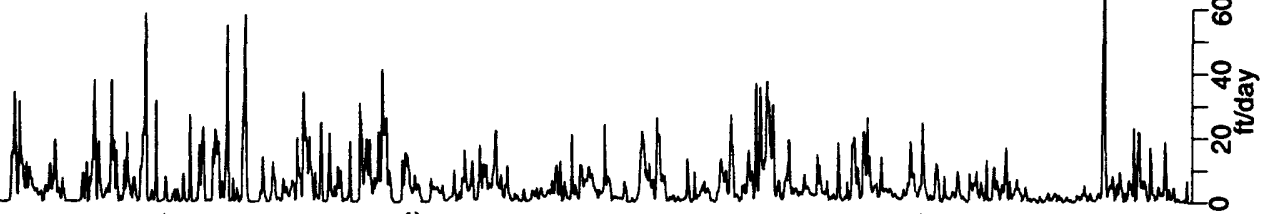

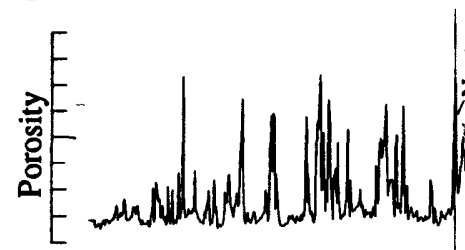

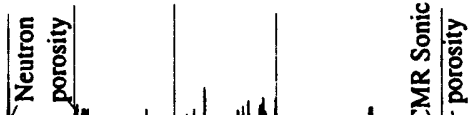

Nowlowillow

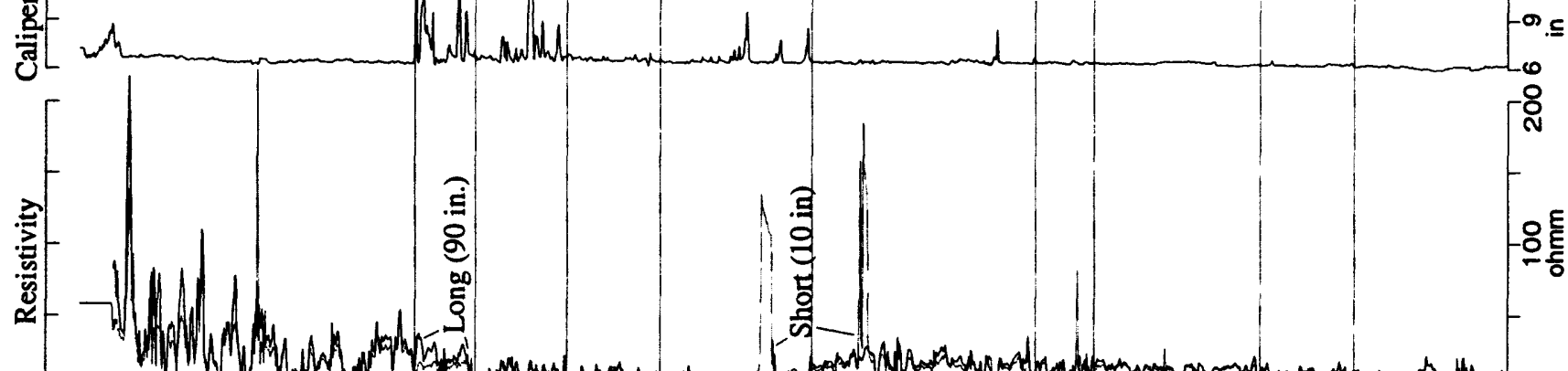

:

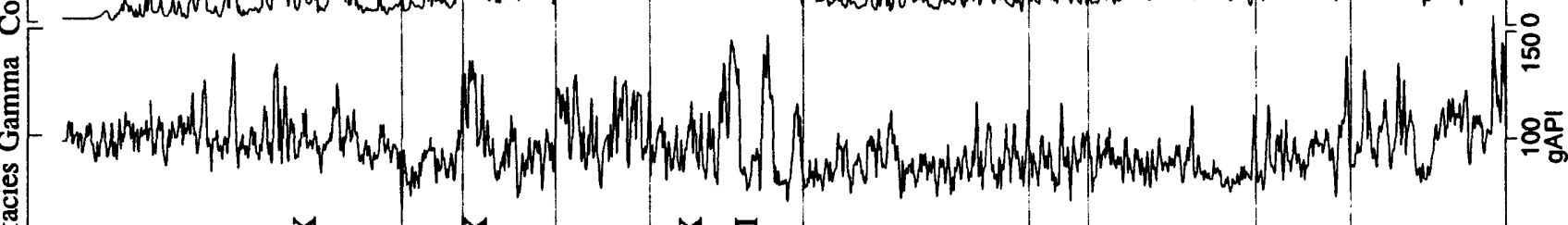

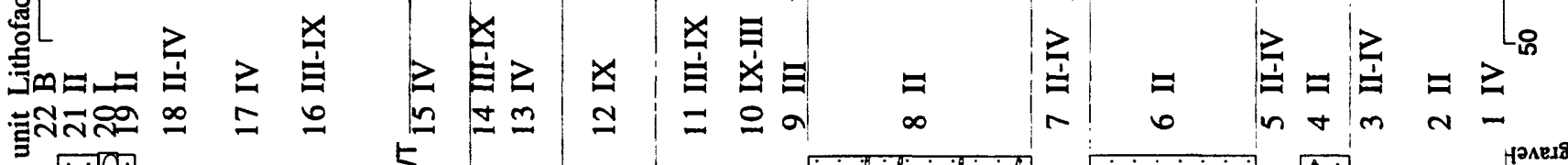

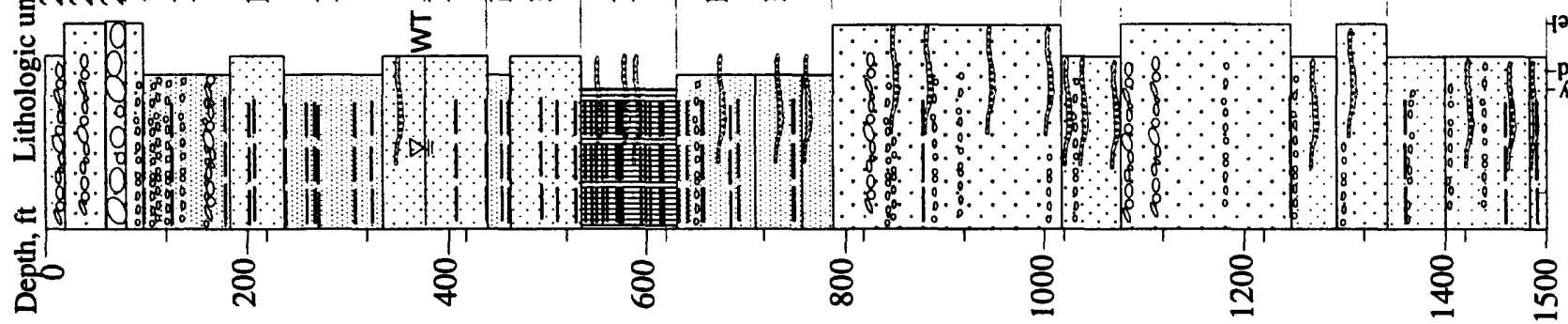

Figure 3. Selected geophysical logs and lithologic units of the 98th Street core hole. 
Table 2. Particle-size Parameters of 98th Street Core Channel Samples

\begin{tabular}{|c|c|c|c|c|c|c|}
\hline Sample & Mode, phi units & $\begin{array}{l}D_{50,} \text { phi } \\
\text { units }\end{array}$ & $\mathbf{C}_{\mathrm{c}}$ & $\mathbf{C}_{\mathbf{U}}$ & Grading & Sorting \\
\hline Unit 1 (1483'-1496') & Silty fine sand, $2-3$ & $2.5-3$ & 1.32 & 4.00 & Uniform & Poorly sorted \\
\hline Unit 2 (1399'-1483' & Silty fine sand, $2-3$ & $2-2.5$ & 1.20 & 2.40 & Uniform & Poorly sorted \\
\hline Unit 3 (1341'-1399' & Silty fine sand, 2-3 & $2-2.5$ & 0.86 & 3.00 & Uniform & Poorly sorted \\
\hline Unit $4\left(1291^{\prime}-1341^{\prime}\right)$ & Medium sand, 1-2 & $1.5-2$ & 1.47 & 3.40 & Uniform & $\begin{array}{l}\text { Moderately to poorly } \\
\text { sorted }\end{array}$ \\
\hline Unit $5\left(1246^{\circ}-1291^{\prime}\right)$ & Silty fine sand, 2-3 & $1.5-2$ & 1.23 & 3.17 & Uniform & Poorly sorted \\
\hline Unit $6\left(1076^{\prime}-1246^{\prime}\right)$ & Medium sand, 1-2 & 2 & 1.19 & 2.33 & Uniform & $\begin{array}{l}\text { Moderately to poorly } \\
\text { sorted }\end{array}$ \\
\hline Unit $7\left(1017^{\prime}-1076^{\prime}\right)$ & Silty fine sand, 2-3 & $2-2.5$ & 0.95 & 2.70 & Uniform & Poorly sorted \\
\hline Unit 8 (786'-1017') & Medium sand, 1-2 & $1.5-2$ & 1.16 & 2.69 & Uniform & $\begin{array}{l}\text { Moderately to poorly } \\
\text { sorted }\end{array}$ \\
\hline Unit $9\left(751^{\prime}-786^{\prime}\right)$ & Clayey, sandy silt, 5 & $1-1.5$ & 0.74 & 6.67 & Uniform & Very poorly sorted \\
\hline Unit 10 (710'-751') & Clayey, sandy silt, 5 & $2-2.5$ & 0.29 & 8.24 & Uniform & Very poorly sorted \\
\hline Unit $11\left(624^{\prime}-710^{\prime}\right)$ & Clayey, sandy silt, 5 & $1.5-2$ & 0.85 & 4.70 & Uniform & Very poorly sorted \\
\hline Unit $12\left(535^{\prime}-624^{\prime}\right)$ & Silt and clay, $\leq 8.5$ & 2 & 1.52 & 9.25 & Well & Poorly sorted \\
\hline Unit 13 (464'-535') & Silty fine sand, 2-3 & $2-2.5$ & 1.33 & 5.33 & Uniform & Poorly sorted \\
\hline Unit $14\left(441^{\prime}-464^{\prime}\right)$ & Clayey, sandy silt, 5 & $2-2.5$ & 1.47 & 7.55 & Well & Very poorly sorted \\
\hline Unit 15 (336'-441') & Silty fine sand, 2-3 & $2-2.5$ & 0.88 & 3.00 & Uniform & Poorly sorted \\
\hline Unit $16\left(237^{\prime}-336^{\prime}\right)$ & Clayey, sandy silt, 5 & $2-2.5$ & 1.04 & 2.74 & Uniform & Very poorly sorted \\
\hline Unit 17 (183'-237') & Silty fine sand, $2-3$ & $2-2.5$ & 1.13 & 2.84 & Uniform & Poorly sorted \\
\hline Unit $18\left(97^{\prime}-183^{\prime}\right)$ & Clayey, sandy silt, 5 & $2-2.5$ & 1.00 & 2.78 & Uniform & Very poorly sorted \\
\hline Unit $19\left(80^{\prime}-97 '\right)$ & Medium sand, 1-2 & $2-2.5$ & 1.07 & 2.70 & Uniform & $\begin{array}{l}\text { Moderately to poorly } \\
\text { sorted }\end{array}$ \\
\hline Unit $21\left(19^{\prime}-60^{\prime}\right)$ & Medium sand, 1-2 & $1-1.5$ & 1.10 & 3.92 & Uniform & $\begin{array}{l}\text { Moderately to poorly } \\
\text { sorted }\end{array}$ \\
\hline Unit 18 (97.2-98.6') & Fine sand, 2-2.5 & $2.5-3$ & 1.02 & 2.93 & Uniform & Moderately sorted \\
\hline Unit $18\left(116^{\prime}-118^{\prime}\right)$ & Medium sand, 1.5-2 & $3-3.5$ & 0.97 & 2.05 & Uniform & Moderately sorted \\
\hline Unit 18 (145.9'-147.9') & Medium sand, 1.5-2 & $3.5-4$ & $1.03^{*}$ & $2.31^{*}$ & Uniform & Moderately sorted \\
\hline Unit $18\left(160.9^{\prime}-162.9^{\prime}\right)$ & Coarse sand $0.5-1$ & $4.5-5$ & $1.01 *$ & $4.8^{*}$ & Uniform & Poorly sorted \\
\hline Unit $18\left(172.6^{\prime}-174.5^{\prime}\right)$ & Silty fine sand, 2-3 & $3-3.5$ & 0.90 & 2.4 & Uniform & Poorly sorted \\
\hline Unit 17 (203'-205') & Coarse sand, $0.5-1$ & $2.5-3$ & $1.70^{*}$ & $3.82 *$ & Uniform & Poorly sorted \\
\hline Unit $16\left(243^{\prime}-245^{\prime}\right)$ & Silty fine sand, 2-3 & $3.5-4$ & $0.86 *$ & $3.6^{*}$ & Uniform & Poorly sorted \\
\hline Unit $16\left(334^{\prime}-336^{\prime}\right)$ & Medium sand, 3-3.5 & 3 & 1.13 & 2.67 & Uniform & Moderately sorted \\
\hline
\end{tabular}

*Values based on estimated grain-size percentages 
that measures of central tendency, $D_{50}$ (median) and modal size class, are closely related for the coarsergrained, medium and fine sand samples. For finergrained units, channel samples have median values coarser than the estimated modal class, possibly due to sampling error or to biased emphasis on the finer grained beds in these lithologic units. Each channel sample integrates a group of texturally related beds within each lithologic unit, which tends to produce uniformly (poorly) graded samples. Sorting values generally are inversely related to grading, such that moderately sorted medium sand is equivalent to uniformly (poorly) graded sand with relatively low $\mathbf{C}_{\mathbf{U}}$ values (2.05-3.92). Samples of poorly sorted silty fine sand correspond to poorly graded sand and silt with $\mathrm{C}_{\mathrm{U}}$ values of 2.4 to 5.33 , and very poorly sorted clayey, sandy silt corresponds to poorly to well graded sand and silt with $\mathbf{C}_{\mathrm{U}}$ values of 2.74 to 8.24. The sample from clay-rich unit 12 , consisting of poorly sorted silt and clay, is equivalent to well graded silty sand and clayey silt with a $C_{U}$ value of 9.25 (fig.4).

\section{PRINCIPAL SEDIMENT TYPES}

Six principal sediment types, each comprising beds with similar grain size, stratification, and composition, are used to describe the core, and to divide it into 22 lithologic units, each of which is composed of a single principal sediment type (fig. 2). As shown in figures 2 and 3, and described in table 4, each of these lithologic units is correlated with specific genetic lithofacies presently recognized in the Middle Rio Grande Basin (Hawley and others, 1995; Hawley, 1996). The lithologic units (lithofacies) have characteristic geophysical-log signatures, and lithic parameters that affect ground-water production (fig. 3; Haase and Lozinsky, 1992; Connell and others, 1998). In the 98th Street area, basin-floor fluvial lithofacies comprising sand and gravel (lithofacies I), sand with lenses of pebbly sand, silt, and silty clay (lithofacies II), and interbedded sand, silt, and silty clay (modified lithofacies III, IV, IX) are dominant in the upper and middle Santa Fe units. Thin beds or sets of beds containing clay, coarse sand, gravel, or sandstone are shown as overprint patterns on the lithologic units in figures 2 and 3 . The six principal sediment types are described in decreasing abundance:
Silty fine sand -- Brown, yellowish brown, to light gray, consisting of a sand framework with a fine sand mode (2-3 phi), and with a range of sand particles from very fine sand to medium sand in most strata. Scattered coarse sand grains are present in some beds. Coarse silt is dispersed as a matrix that partially fills pores. Estimated sorting is poor. The value of $D_{10}$ is estimated to be within the silt matrix. The strata commonly appear massive to indistinctly laminated (fig. 5). However, some beds contain opaque dark minerals which form distinct laminae. Sand mineralogy appears to be, in decreasing abundance: quartz, orthoclase feldspar, plagioclase feldspar, hornblende or hypersthene, magnetite, and other heavy minerals, which is similar to feldspathic litharenite to lithic arkose compositions reported for other sands in the basin (Mozley and others, 1992, Large, 1995). Quartz grains are elongated, subangular to rounded, exhibit straight extinction and preserve some crystal faces, and are inferred to be of volcanic origin. Feldspar grains are elongate, subangular. Other lithic types that commonly are interbedded with silty fine sand include silty clayey sand, silty sand, very fine sand, and clayey medium sand. Some strata composed of fine sand and fine-to-medium sand without silt matrix are present as interbedded units within these sequences. In geophysical logs (fig.3), silty fine sand is characterized by highly variable baselines, typically with deflections ranging from 76 to 120 gAPI units around a baseline value of about $100 \mathrm{gAPI}$ units for natural gamma. Deflections in gamma, conductivity, and porosity logs show vertical variability of $2-5 \mathrm{ft}$ (0.6-1.5 m) wave lengths, which is correlated with interbedded sequences of silt, clay, and sorted fine sand strata within the silty sand. Units typically include scattered clay strata, $>0.2 \mathrm{ft}(6 \mathrm{~cm})$ thick, which produce sharp, high-amplitude spikes that are correlated between gamma ( $>120$ to $>150$ gAPI units) and conductivity logs, and are inversely related to low values of resistivity. Thin clay beds, or silty clay beds produce low-amplitude spikes in both logs. Density values of 2.12-2.25 g/cc and porosity values of 30-35 percent are typical values for these parameters in unconsolidated fine sand (Pryor, 1973; Keys; 1989. Schlumberger, 1989, 1991). 
Table 3. Sediment types of the 98th Street Core.

Units shown in bold type are six principal sediment types used to describe the stratigraphy of the core (fig. 2). These units include related sediment types (field descriptions) shown below each principal sediment type. Thickness percentages of the total cored interval for each principal sediment type, based on lithologic units (fig. 2), are shown in parentheses.

\begin{tabular}{|c|c|c|c|c|}
\hline $\begin{array}{l}\text { Principal Sediment Type } \\
\text { Related sediment types }\end{array}$ & $\begin{array}{l}\text { Grain-Size } \\
\text { Mode (phi) }\end{array}$ & $\begin{array}{l}\text { Grain-Size } \\
\text { Range (phi) }\end{array}$ & $\begin{array}{c}\text { Grain size } \\
\mathbf{D}_{10} \text { (phi) }\end{array}$ & $\begin{array}{l}\text { Color } \\
\text { Munsell values }\end{array}$ \\
\hline Silt and clay ( $6.3 \%)$ & 8.5 & $8-12$ & 10 & $2.5 Y R 4 / 6,2.5-5 Y R 5 / 4$ \\
\hline Clayey sandy silt (24.3\%) & 5 & $2-12$ & 8 & $7.5 Y R 5 / 4$ \\
\hline Silty clay & 8.25 & & & \\
\hline Clayey silt & 7 & & & \\
\hline Sandy clayey silt & 6 & & & \\
\hline Sandy silt & 4.5 & & & \\
\hline Silty fine sand $(34.1 \%)$ & 3.6 & $7-.75$ & 4.25 & $7.5 Y R 5-6 / 4$ \\
\hline Silty clayey sand & 3.9 & & & \\
\hline Silty sand & 3.8 & & & \\
\hline Very fine sand & 3.5 & & & \\
\hline Fine sand & 2.5 & & & \\
\hline Fine to medium sand & 2 & & & \\
\hline Clayey medium sand & 1.75 & & & \\
\hline Medium sand (33.8\%) & 1.5 & $3-0.0$ & 2.5 & 10 YR5-6/2-4 \\
\hline Coarse sand & -.5 & & & \\
\hline Sand and gravel (1.3\%) & -1.75 & & & \\
\hline Coarse sand with granules & -1.5 & & & \\
\hline Pebble gravel & -4.5 & & & \\
\hline Cobble gravel & -6 & & & \\
\hline Sandstone $(<0.3 \%)$ & 2.5 & $5-1.5$ & 3 & $10 \mathrm{YR} 5 / 2$ \\
\hline Medium sandstone & 1.5 & & & \\
\hline Siltstone & 4.75 & & & \\
\hline
\end{tabular}

Medium sand -- Light brown to gray, consisting chiefly of medium sand beds, and scattered beds of medium to coarse sand, and beds of granular to pebbly sand. Sand strata consist of a sand framework with variable modes (1-2 phi), and with a range of sand particles from very fine sand to coarse sand in most strata. Pebbly sand strata consist of a sand framework with medium sand modes (1-2 phi), and with scattered or locally a framework of pebble-gravel clasts. For medium sand beds, the estimated sorting is moderate to poor, and the value of $\mathrm{D}_{10}$ is estimated to be within the fine sand fraction ( $2.5 \mathrm{phi})$. For coarse sand beds, the estimated sorting is poor, and the value of $D_{10}$ is estimated to be within the medium sand fraction (1.5 phi). For pebbly sand beds, the estimated sorting of the sand matrix is poor, and the value of $D_{10}$ is estimated to be within the fine sand fraction (2.5 phi). The strata commonly appear massive to indistinctly laminated. However, some beds contain distinct laminae composed of opaque or dark minerals. Sand mineralogy appears to be, in decreasing abundance: quartz, orthoclase feldspar, plagioclase feldspar, lithic fragments of quartzite, volcanic rocks, chert, granite, and heavy minerals hornblende or hypersthene, magnetite, and other heavy minerals, which is similar to feldspathic litharenite to lithic arkose compositions reported for other sands in the basin (Mozley and others, 1992, Large, 1995). Quartz grains commonly are elongated, subangular, exhibit straight extinction and preserve some crystal faces, and are inferred to be of volcanic origin. Feldspar grains are elongate, subangular. Other lithic types that commonly are interbedded with medium sand are coarse sand, and beds of granular to pebbly sand and pebble gravel. Some strata composed of fine sand, and silty fine sand are present as inter- 
bedded units within these sequences. In geophysical logs (fig. 3), medium sand is characterized by baselines of low variability, typically with deflections ranging from 70 to 105 gAPI units around a baseline value of about 90 gAPI units for natural gamma. Deflections in gamma, conductivity, and porosity logs show vertical variability of 2-4-ft (0.6-1.2 m) wave lengths, which are correlated with interbedded sequences of silt, clay, and sorted fine sand strata within the sand. Units typically include scattered, thin clay strata, $>0.2 \mathrm{ft}(6 \mathrm{~cm})$ thick, which produce sharp, high-amplitude spikes that are correlated between gamma ( $>120$ to $>150$ gAPI units) and conductivity logs. Thin silty clay strata produce low-amplitude spikes in both logs. Density values of $2.05-2.20 \mathrm{~g} / \mathrm{cc}$ and porosity values of 30-35 percent are typical values for these parameters in unconsolidated medium sand (Pryor, 1973; Keys, 1989; Schlumberger, 1989, 1991). Density values $>2.25 \mathrm{~g} / \mathrm{cc}$, correlated with low porosity values, are related to thin beds of sandstone.

Clayey sandy silt -- Brown to gray, consisting of a very poorly sorted mixture of silt with variable clay matrix, with a coarse silt mode (5 phi), and with a range of particles from clay to medium sand in some strata. The value of $D_{10}$ is estimated to be in the fine silt fraction. The strata commonly appear massive but locally are indistinctly laminated (fig.5). Some strata contain solitary or sets of microlaminations of red clay or gray silty fine sand. Air-dried samples of clayey silt have low to medium dry strength and have low plasticity or are nonplastic (ASTM, 1995). Silt and sand mineralogy appears to be dominated by light minerals, in decreasing abundance: quartz, plagioclase feldspar, and dark or opaque heavy minerals. Quartz and feldspar grains are elongated, subangular. This sediment type includes poorly sorted brown silty clay, clayey and sandy silt with scattered fine to medium sand grains, clayey silty sand, and beds composed of sets of microlaminated clay and silt. In geophysical logs (fig. 3), clayey and sandy silt sequences are characterized by highly variable baselines, typically with deflections ranging from 79 to 120 gAPI units around a baseline value of about $105 \mathrm{gAPI}$ units for natural gamma. Deflections in gamma, conductivity, and porosity logs show vertical variability of $2-4 \mathrm{ft}$ (0.6-1.2 m) wave lengths, which are correlated with interbedded sequences of clay and fine sand strata within the silt. Units typically include interbedded clay strata, $>0.2 \mathrm{ft}(6 \mathrm{~cm})$ thick, which produce sharp, high-amplitude compound spikes that are correlated over 10-20-ft (3-6.1 m) vertical intervals between gamma ( $>120$ to $>150$ gAPI units) and conductivity logs. Thin clay strata, or silty clay strata produce numerous low-amplitude spikes in both logs. Density values of 2.1-2.2 $\mathrm{g} / \mathrm{cc}$ and porosity values of 30-40 percent are typical values for these parameters in unconsolidated silt (Pryor, 1973; Keys, 1989; Schlumberger, 1989, 1991).

Silt and clay -- Red to reddish brown, consisting of homogeneous to indistinctly microlaminated clay, with a clay mode ( $\leq 8.5 \mathrm{phi}$ ), perhaps containing minor fine silt, but no coarse silt or sand, and interbedded brown to gray silt. The value of $D_{10}$ is estimated to be in the clay fraction (10 phi). Clay strata are present as thin beds, laminae, and micro laminations (fig. 5) throughout the core. Air-dried samples of clay have medium to high dry strength and have medium to high plasticity (ASTM, 1995). Clay is identified by its red color and plasticity and this sediment type excludes other fine-grained sediment types that are nonplastic. Clay beds and associated laminated silt and clay sequences constitute a major fine-grained interval in the middle part of the core (fig. 2). In geophysical logs (fig.3), the clay and silty clay sequence is characterized by a variable baseline, typically with deflections ranging from 84 to 120 gAPI units around a baseline value of about 105 gAPI units for natural gamma. Deflections in gamma, conductivity, and porosity logs show vertical variability of 2-4 $\mathrm{ft}$ (0.6-1.2 $\mathrm{m}$ ) wave lengths, which are correlated with interbedded sequences of silt, and fine sand strata within the clay. Lithologic unit 12 includes relatively thick sequences of clay strata, $>0.2$ $\mathrm{ft}(6 \mathrm{~cm})$ thick, which produce broad, high-amplitude compound spikes that are correlated over $10-\mathrm{ft}(3-\mathrm{m})$ vertical wave lengths between gamma $(>120$ to $>150$ gAPI units) and conductivity logs. Thin clay strata, or silty clay strata produce numerous low-amplitude spikes in both logs. Density values of $2.12-2.25 \mathrm{~g} / \mathrm{cc}$ and porosity values of $>45$ percent are typical values for these parameters in poorly consolidated, undrained clay (Keys, 1989; Schlumberger, 1989, 1991). 
Sand and gravel -- Interbedded framework gravel beds, containing sand matrix, and beds of sand. Sand strata consist of a sand framework with variable sand modes (1-3 phi). The estimated sorting of sand beds is poor, and the value of $D_{10}$ is estimated commonly to be within the medium sand fraction (1.5 phi). Gravel beds consist of a framework gravel, with gravel modes varying from small pebbles to small cobbles, and containing a poorly sorted sand matrix. The value of $D_{10}$ of the sand matrix is estimated to be within the fine sand fraction ( $2.5 \mathrm{phi})$. For pebbly sand beds, the estimated sorting of the sand matrix is poor. The strata commonly were disrupted by the drilling process. However, some core samples of thin sand and fine pebble beds were preserved and these contain distinct laminae composed of contrasting grain sizes. Sand mineralogy appears to be, in decreasing abundance: quartz, orthoclase feldspar, plagioclase feldspar, lithic fragments of quartzite, volcanic rocks, chert, granite, and heavy minerals hornblende or hypersthene, magnetite, and other heavy minerals. Quartz and feldspar grains commonly are elongated, subangular. Lithic fragments are elongate, tabular or subspherical, angular to subangular. Other sediment types that commonly are interbedded with sand and gravel include fine sand, and silty fine sand. In geophysical logs (fig. 3), sand and gravel is characterized by variable baselines, typically with deflections ranging from 88 to 106 gAPI units around a baseline value of about 98 gAPI units for natural gamma. Deflections in gamma and porosity logs show vertical variability of 3-10 ft (0.9-3 m.) wavelengths, which are correlated with interbedded sequences of silty and sorted fine sand, and gravel strata within the deposit.

Sandstone -- Light brown to gray, consisting chiefly of fine-to-medium grained sandstone, indurated and cemented by carbonate, and minor siltstone.

Carbonate cement is chiefly calcite, varying from microsparry in the upper part of the core, to sparry in lower parts of the core (fig. 6). The cement virtually fills the entire original pore space, locally overgrowing iron/manganese stains on sand grains. These lithified thin beds are scattered throughout the core below the $100-\mathrm{ft}(30-\mathrm{m})$ depth. Carbonate in nodular concretions, discontinuous patches, and thin lenses (fig. 5) is scattered throughout the core. Carbonate morphology is controlled in part by grain size of the host beds (Mozley and others, 1992) and calcite appears to have grown selectively on sand or silty sand at contacts with finer-grained sediments. In geophysical logs (fig. 3), sandstone beds are characterized by density values $>2.25 \mathrm{~g} / \mathrm{cc}$ and porosity values $<30$ percent. Thin sections of sandstone beds (fig. 6) reveal that most primary porosity has been filled with calcite cement. 
Table 4. Lithologic units and related lithofacies of the 98th Street core .

\section{Unit Depth}

$22 \quad 0-19$ Description

$21 \quad 19-60$ Fine to medium sand with scattered coarse sand and granular to pebbly sand intervals; 10YR 6/3-5/4

$20 \quad 60-80 \quad$ Pebble to cobble gravel

$19 \quad 80-97$ Fine to coarse sand and silty sand with scattered interbeds of granular and pebbly sand; 7.5-10YR5/4

$18 \quad 97-183$

$16 \quad 237-336$

Fine to coarse sand and silty sand with interbeds of silty fine sand grading into thin $(<1 \mathrm{ft})$ silty clay and clay layers; granular pebbly sand from 158.9 to $64.1 \mathrm{ft}$ depth; 7.5-10YR5-4/4 (sand) 5-7.5YR5-4/4 and 2.5-5YR6/4-4/6 (clay) to $210.9 \mathrm{ft}$ depth; 7.5 YR./4-4/6 (sand), 5 YR5/4 (clay)
$17 \quad 183-237$

Fine to coarse sand; sandy, silty clay interbred from $204.5 \mathrm{ft}$ Interbedded silty fine to medium sand and clay and silty clay; thick clay beds ( $>1 \mathrm{ft}$ thick) from 237.2 to $264.0 \mathrm{ft}$ depth; 7.5YR6-4/4 and 7.5YR5/6 (sand), 2.5-5YR6-4/4 and 5 YR5/6 (clay)

15 336-441 Fine to medium sand and silty sand with thin lenses and interbeds of silty clay and clay; 7.5YR6-4/6 (sand), 5YR5/4 (clay)

14 441-464 Interbedded silty fine sand, silty clay and clay, and fine to medium sand; some clay beds are more than $2 \mathrm{ft}$ thick; 7.5YR5/4-6 (sand), 5YR5/4-4/6 (clay)

13 464-534 Fine to medium sand and silty sand with thin interbeds of silty IV clay and clay; 7.5YR5/4-4/6 and 10YR6-5/4-6 (sand), 5-7.5 YR5/4-4/6 (clay)

12 534-630 Clay and silty clay with interbedded fine to medium silty sand; IX finely laminated clay beds from 544 to $606 \mathrm{ft}$ depth; 7.5-10YR5-6/4 (sand), 5-7.5YR5/4-4/6 (clay)

11 630-709 Fine to medium sand and silty sand with silty clay interbeds; III, IX 10YR6/3-4/4, 7.5YR6-4/4 (sand), 7.5-10YR5-4/4 (clay)

$10709-756$ Silty fine sand with laminated clay interbeds at 712.9 to

\section{Lithofacies ${ }^{1}$}

B--Valley border alluvial-fan sand and gravel ; sand and gravel

II--Basin-floor fluvial and eolian sand; lenses of pebbly sand, silt, and silty clay

I--Fluvial cobble to pebble gravel, sand, silt, and silty clay

II--Basin-floor fluvial and eolian sand; sand,

II, lenses of pebbly sand, silt, and silty clay

IV--Basin-floor eolian and distal piedmont alluvial fan; sand and silt; lenses of silty clay and clay

IV

III--Basin-floor alluvial, playa lake, and eolian interbedded sand, silt, silty clay; lenses of pebbly sand

IX--Basin-floor playa lake and alluvial flat, distal piedmont alluvial silty clay interbedded with silty sand, silty clay, and clay

IV

III, IX

\section{IV}

IX, III 
Table 2 (continued). Lithologic units and related lithofacies of the 98th Street core .

\begin{tabular}{|c|c|c|c|}
\hline Uni & it Depth & Description & Lithofacies $^{1}$ \\
\hline 9 & $756-787$ & $\begin{array}{l}\text { Silty fine sand with silty clay interbeds, fine to medium sand } \\
\text { with scattered coarse sand from } 770 \text { to } 780 \mathrm{ft} \text { depth; pebble } \\
\text { gravel beds near } 776.5 \mathrm{ft} \text { depth; } 10 \text { YR6/6-5/4 and 10YR6/2 } \\
\text { (sand), 5YR5/4 (clay near } 784 \mathrm{ft} \text { depth) }\end{array}$ & III \\
\hline 8 & $787-1017$ & $\begin{array}{l}\text { Fine to medium sand and silty sand with coarse sand layers, } \\
\text { scattered granules, and pebbles; pebble gravel recovered near } \\
825,833,843 \text {, and } 860 \mathrm{ft} \text {; thin }(<1 \mathrm{ft}) \text { silty clay and clay } \\
\text { interbeds between } 850 \text { and } 880 \mathrm{ft} \text { depths and near } 978 \mathrm{ft} \text {; } \\
\text { 10YR6/3-4/4, 7.5YR6-5/4 (sand) }\end{array}$ & II \\
\hline 7 & $1017-1076$ & $\begin{array}{l}\text { Interbedded fine to coarse sand and silty sand, with thin silty } \\
\text { clay interbeds; pebbly sand layer near } 1031 \mathrm{ft} ; 10 \text { YR6/3-4/4 } \\
\text { and } 7.5 \text { YR6-5/4 (sand) }\end{array}$ & II, IV \\
\hline 6 & $1076-1246$ & $\begin{array}{l}\text { Fine to coarse sand with granular and pebbly sand layers; } \\
\text { pebble gravel recovered near } 1085,1113 \text {, and } 1183 \mathrm{ft} \text {; } \\
\text { 10YR6/2-5/4 (sand) }\end{array}$ & II \\
\hline 5 & $1246-1291$ & $\begin{array}{l}\text { Fine to medium sand with scattered thin interbeds of silty } \\
\text { fine sand and clayey silt; pebbly sand near } 1261 \text { and } 1284 \mathrm{ft} \text {; } \\
\text { 10YR6/3-5/4 (sand) }\end{array}$ & II, IV \\
\hline 4 & $1291-1341$ & $\begin{array}{l}\text { Fine to coarse sand with granular and pebbly sand layers; } \\
\text { pebbles recovered near } 1323 \text { and } 1338 \mathrm{ft} \text { depths; } 10 \mathrm{YR} 6-4 / 2 \\
\text { and } 10 \mathrm{YR} 5 / 4 \text { (sand) }\end{array}$ & II \\
\hline 3 & 1341-1399 & $\begin{array}{l}\text { Fine to medium sand and silty sand with thin intervals of } \\
\text { compact silty and clayey silt; } 10 \text { YR6/2-4/3 (sand) }\end{array}$ & II, IV \\
\hline 2 & $1399-1483$ & $\begin{array}{l}\text { Fine to medium sand with scattered coarse and granular sand } \\
\text { layers; } 10 \text { YR5-4/1 and } 10 \text { YR6/2-4/3 (sand) }\end{array}$ & II \\
\hline 1 & $1483-1500$ & $\begin{array}{l}\text { Fine to medium sand with interbedded compact silty fine } \\
\text { sand and clayey silt; } 10 \text { YR5-4/3 (sand) }\end{array}$ & IV \\
\hline
\end{tabular}

\footnotetext{
${ }^{1}$ Lithofacies of Hawley and Haase, 1992, and Hawley, 1996
} 


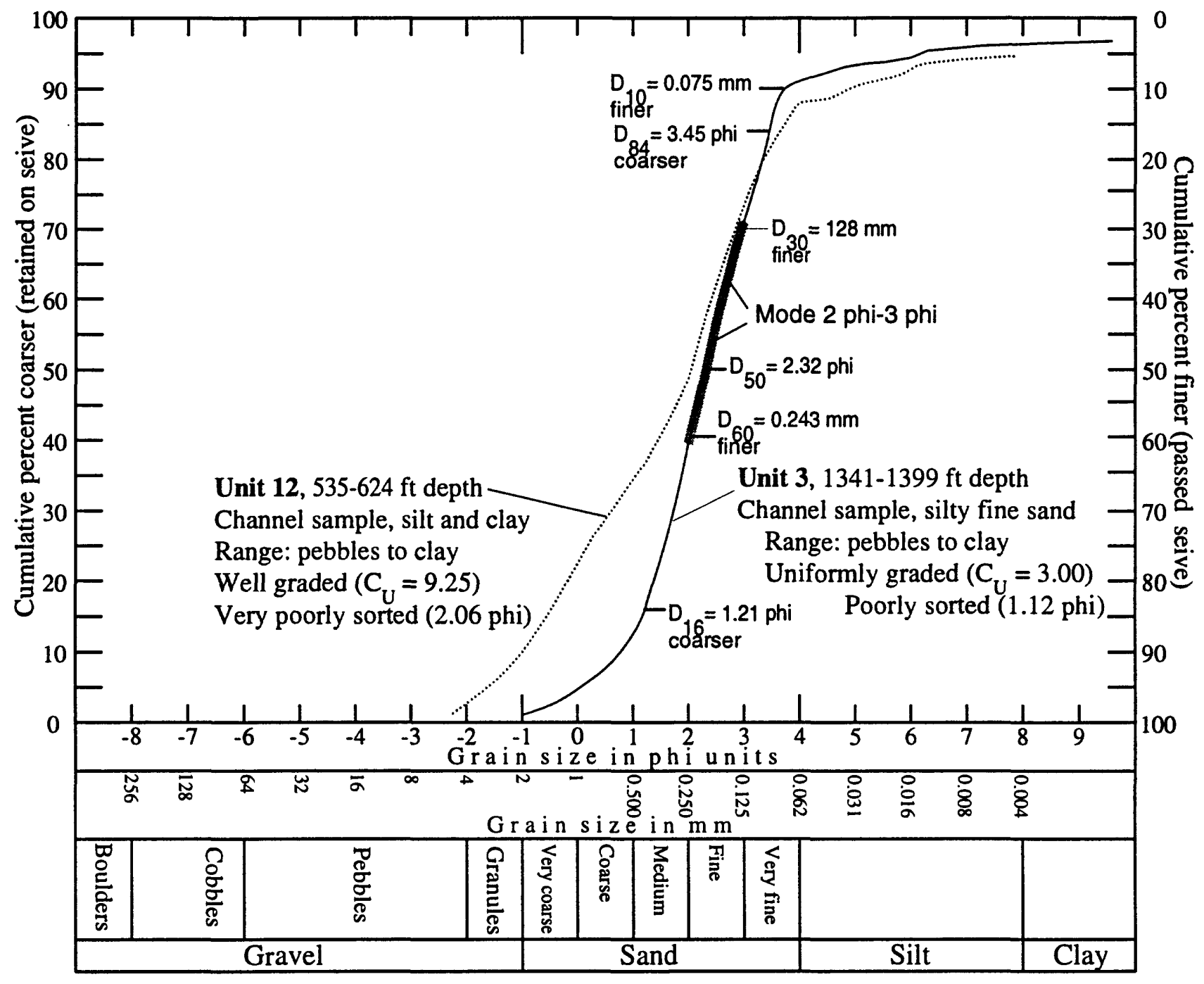

Figure 4. Cumulative particle-size curves for channel samples from lithologic unit 3 (silty fine sand), and lithologic unit 12 (silt and clay). Curve for unit 3 shows values for median $\left(D_{50}\right)$, mode (one-phi interval), range of particle size, $D_{10}, D_{30}, D_{60}$ (finer), $D_{16}$, and $D_{84}$ (coarser) which are used to calculate sorting and gradation of the sample. 

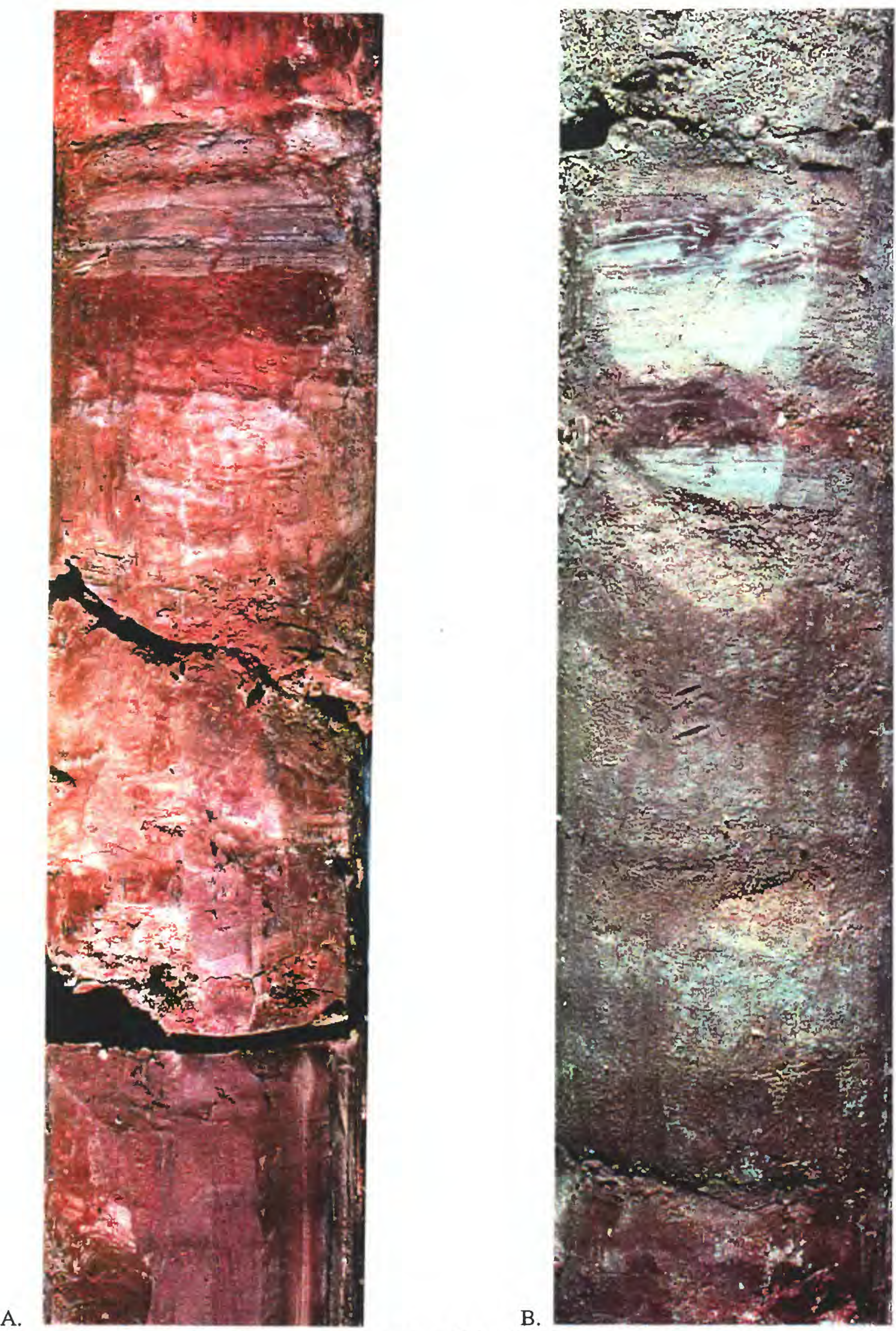

Figure 5. Photographs of typical sediment types of the 98 th Street core. A) reddish brown clay lamination within microlaminated brown silty clay, silt, and clay; top of photo $555.05 \mathrm{ft}$ (169.2 m) depth. B) microlaminated reddish brown clay, and light brown silt and fine sand within light brown to brown medium sand; top of photo $490.0 \mathrm{ft}$ (149.3 m) depth. 

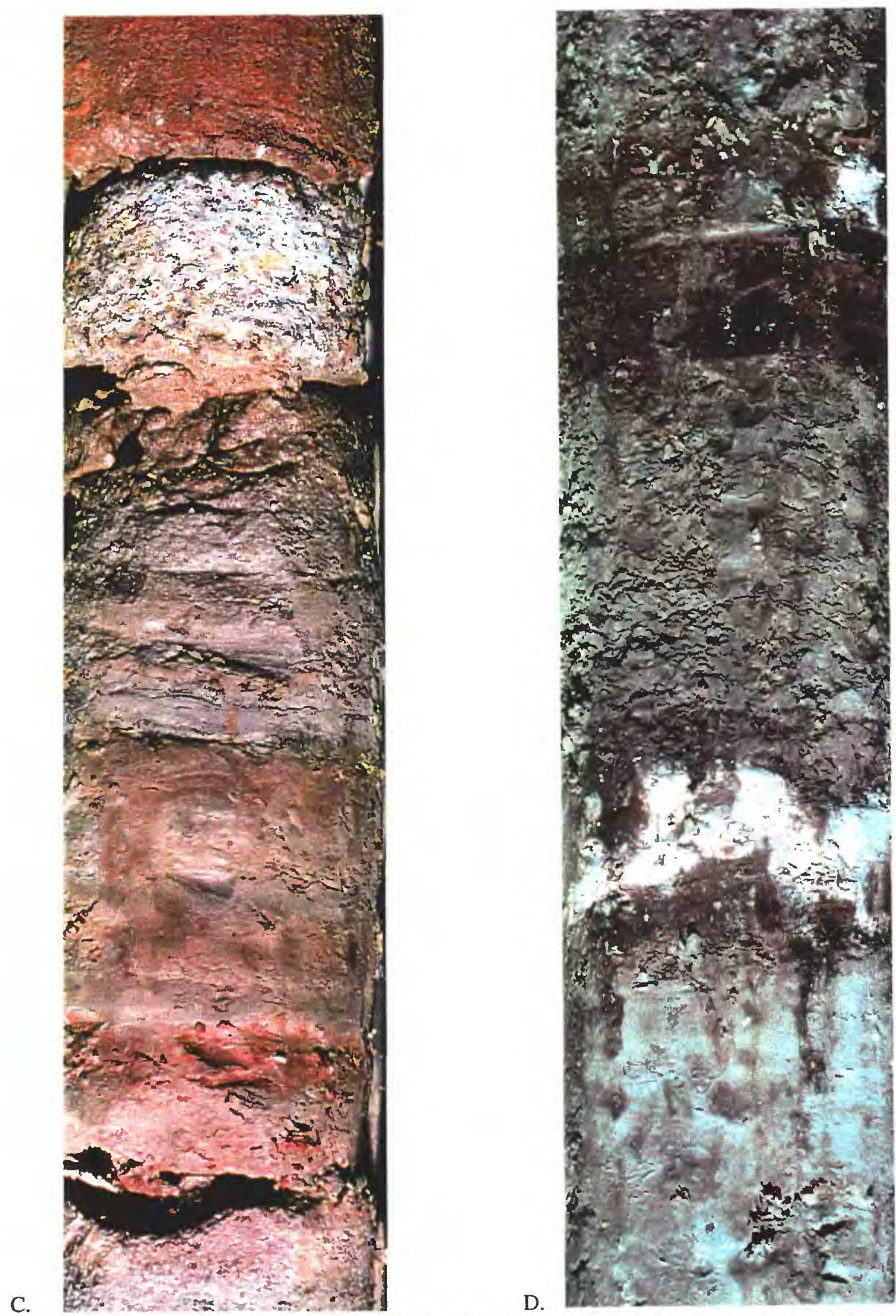

Figure 5, continued. Photographs of typical sediment types of the 98th Street core. C) interbedded brown, pale brown, and yellowish brown silty fine sand, sandy clayey silt, silty clay, strong brown silty fine sand, and light gray medium sandstone; top of photo $549.2 \mathrm{ft}(167.4 \mathrm{~m})$ depth. D) reddish brown clay and irregularly carbonate-cemented clay within brown clayey fine sandy silt; top of photo $783.3 \mathrm{ft}$ (238.7 m) depth. 
A.

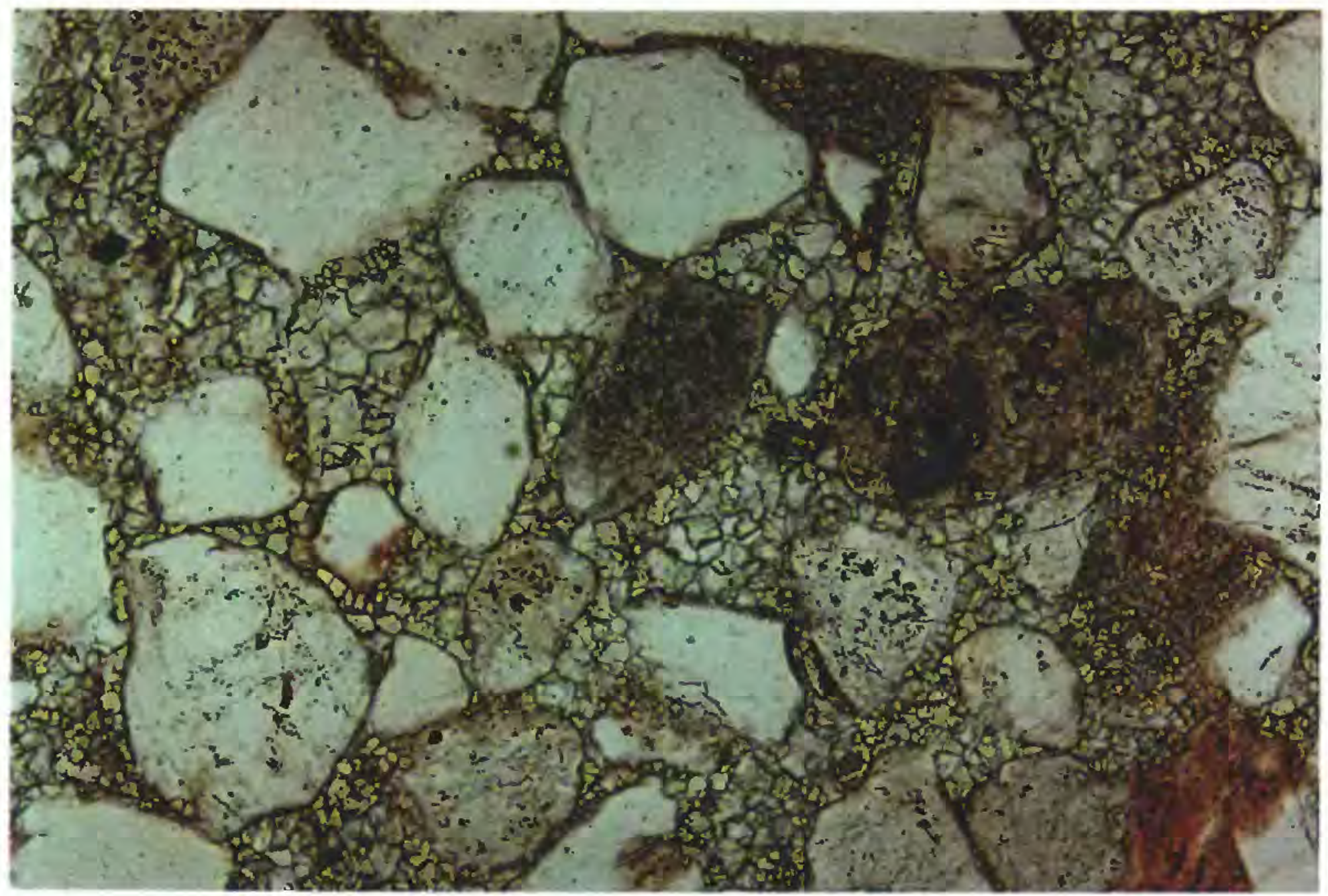

B.

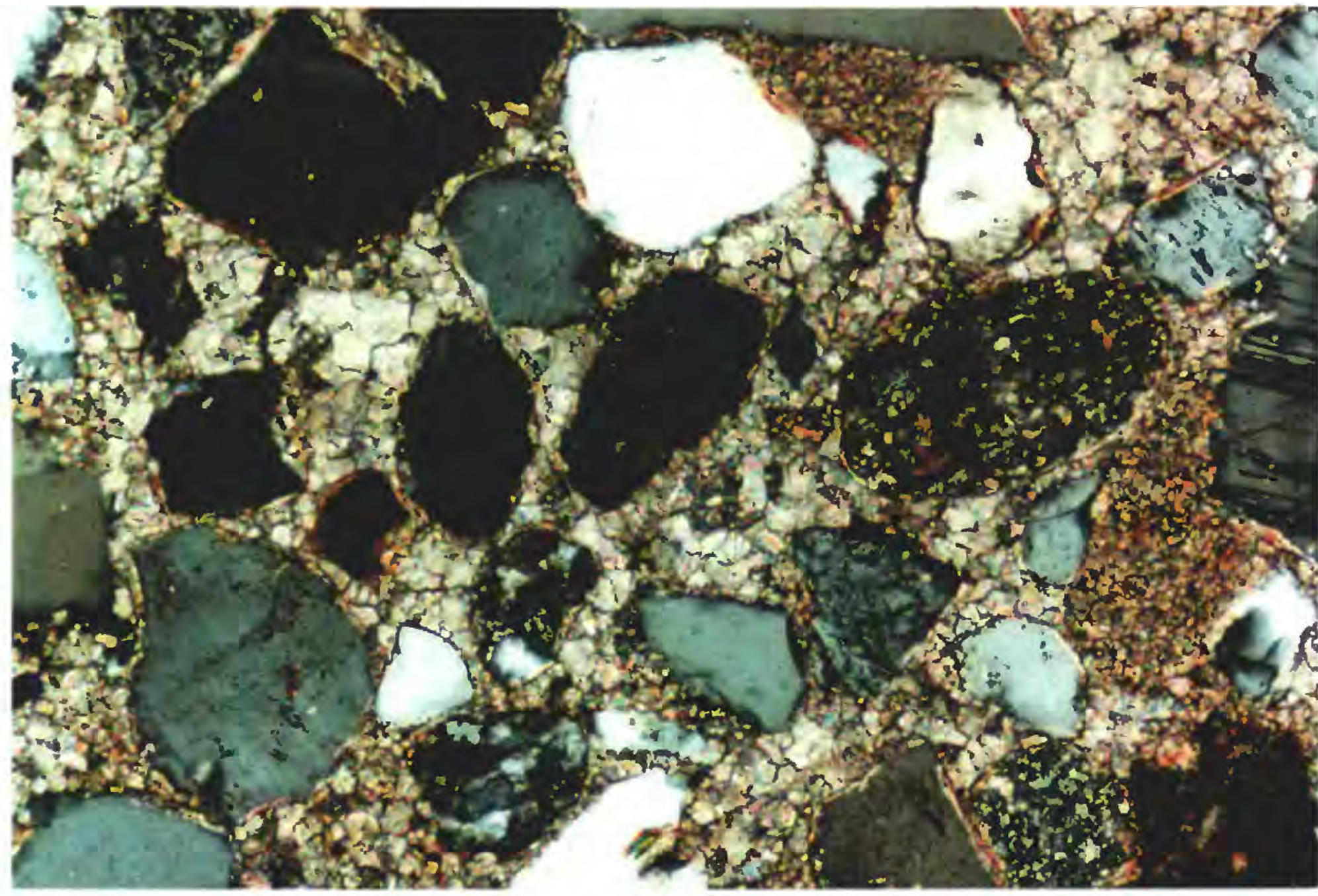

Scale

$0.1 \mathrm{~mm}$

Figure 6. Photomicrographs of thin sections of sandstone in the 98th Street core. A) fine-grained sandstone with microsparry calcite cement, 212-ft depth, plane light, (B) polarized light. 


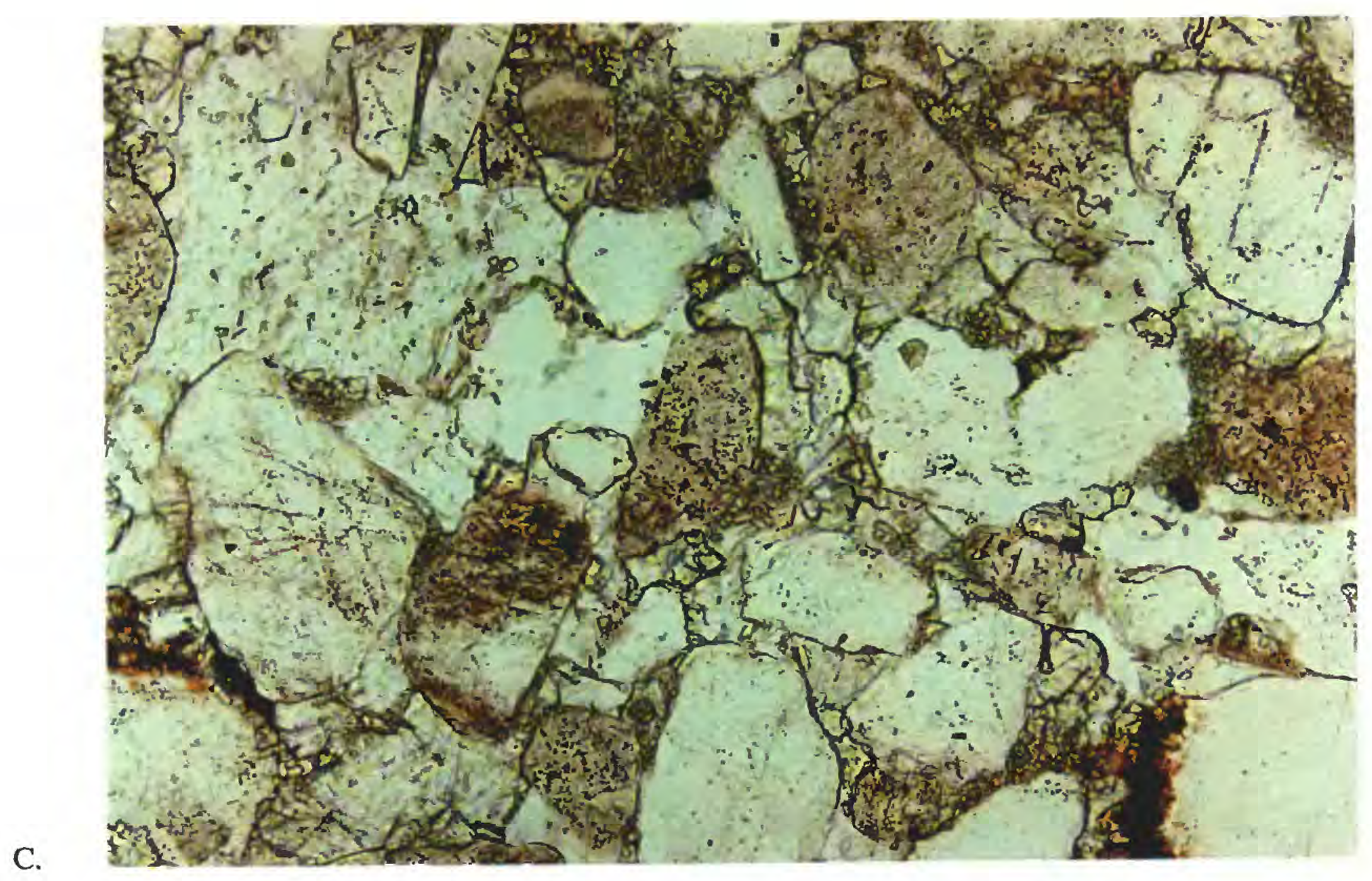

D.

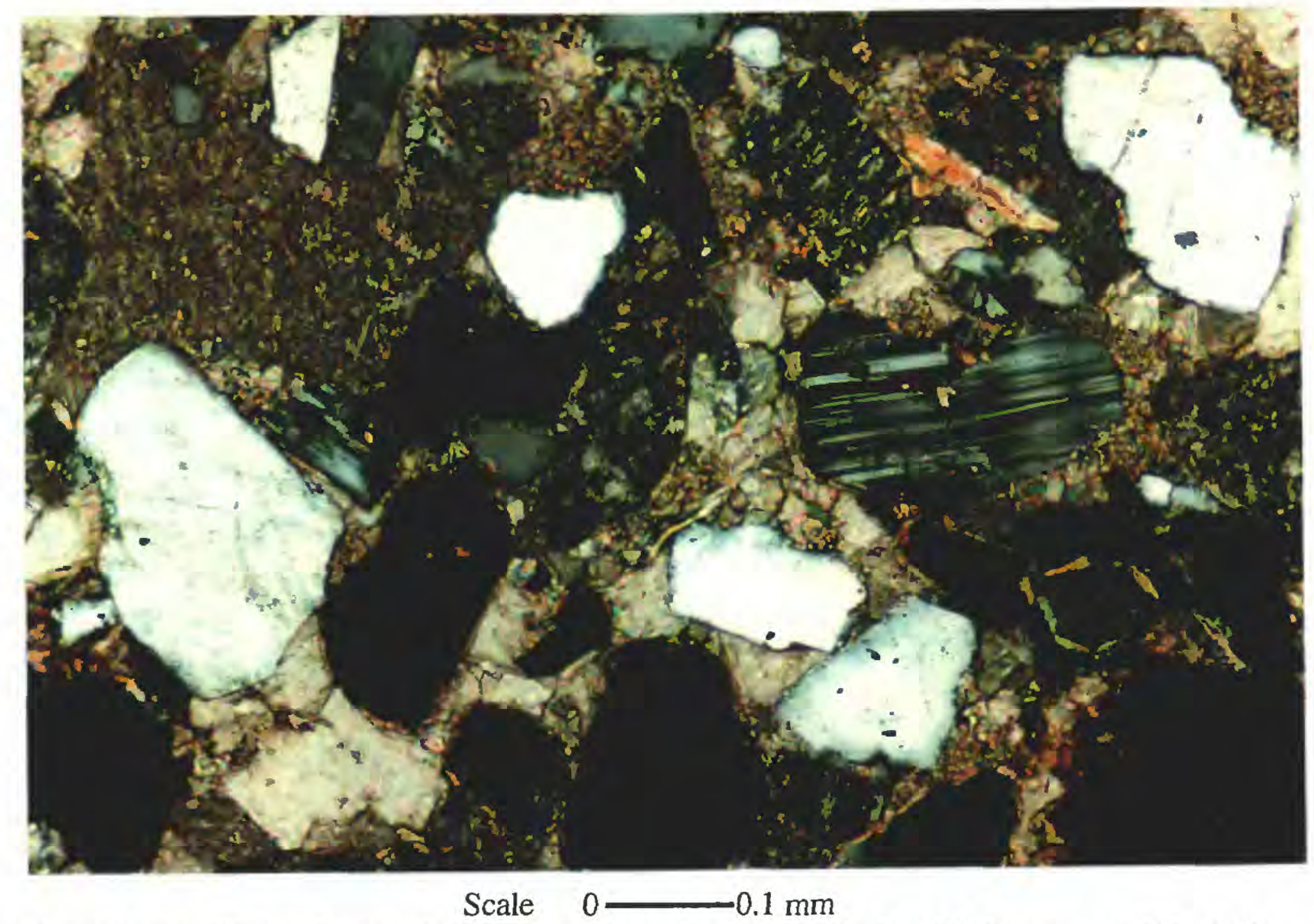

Figure 6, continued. Photomicrographs of thin sections of sandstone in the 98th Street core. (C) medium-grained sandstone with sparry cement, 1005 -ft depth, plane light, (D) polarized light. 


\section{LITHOSTRATIGRAPHY AND DEPOSITIONAL ENVIRONMENTS}

Based on field examination of the core and analysis of geophysical logs, the sediments in the 98th Street core hole are divided into three lithostratigraphic units that are defined primarily by their grain size, color, and composition, which reflects our present understanding of the age of the upper and middle parts of the Santa Fe Group and post-Santa Fe deposits (fig. 7). Correlated lithologic units and lithofacies are shown for each unit in figure 2. The description of inferred depositional environments for each lithostratigraphic unit, including two subunits within the middle Santa Fe deposits, is based on lithic characteristics and vertical sequences of lithofacies. Stacked sequences of texturally similar lithofacies commonly are combined within the larger stratigraphic units, and thus impart characteristic lithologic properties at lithostratigraphic scale, such as the units in figure 7. In some areas, these texturally similar sequences are known also as transition zones or marker zones; the distinctively fine-grained Atrisco member is such a zone. Results of this stratigraphic analysis confirm the previous interpretations of well logs in the area (Hawley and Haase, 1992; Hawley, 1996) that included a sandy and gravelly upper unit overlying a sand-silt-clay unit $200-300 \mathrm{ft}$ (60.1-91.4 $\mathrm{m})$ thick, which in turn overlies sandy units. The core samples revealed the poor sorting of sand strata in the upper part of the middle Santa Fe unit, the scale of laminations in the silt-clay zones, the plasticity and inferred grain size of brown silty clay and red clay beds, the absence of volcanic ash, and the moderately sorted and noncemented nature of the sediments below $800 \mathrm{ft}(243.8 \mathrm{~m})$ depth.

Three informal lithostratigraphic units, and four closely related hydrostratigraphic units summarize the present stratigraphic framework for the 98 th Street site (figs. 7,9 ). The top unit, from the land surface to 19-ft (5.5 m) depth, consists of post-Santa Fe Group surficial sand and gravel, which contains moderately sorted fine sand in the upper part, and fine to medium sand with scattered coarse sand beds, pebbles and cobbles, and gravel beds in the lower part. These late Quaternary deposits include eolian sand, mixed eolian and alluvial sand, and valley-border alluvium which unconformably overlie the Santa Fe Group in the local tributary valley. These surficial sediments constitute the valley-border alluvium hydrostratigraphic unit (unit VA, fig. 9). Interbedded sand and gravel of this unit is exposed in shallow arroyo channels south of the drill site.

The underlying coarse-grained deposits, $19-97 \mathrm{ft}$ (5.5-29.6 m) depth, are correlated with the upper unit of the Santa Fe Group (Hawley, 1996), equivalent to the Ceja Member of the Santa Fe Formation of Kelley (1977) that underlies the Llano de Alburquerque geomorphic surface. Regionally, the upper Santa Fe is correlated with the Sierra Ladrones Formation of Machette (1978) in the southern part of the Albuquerque basin (Hawley, 1996; Allen and others, 1998). The upper Santa Fe is composed of interbedded yellowish brown sand beds, fine to coarse and moderately well sorted, and beds of framework gravel. The proportion of gravel beds increases and the size of gravel clasts coarsens downward through the unit to cobble gravel in the interval $60-80 \mathrm{ft}$ (18.6-24.4 m). This unit is the coarsest in the entire stratigraphic section and is a channel sand-and-gravel deposit that disconformably overlies the middle Santa Fe unit. The upper Santa Fe unit contains basin-floor fluvial sand and pebbly sand, and braid plain sand and pebble-cobble gravel lithofacies. Gravel clasts include abundant chert, pink granite, and quartzite, and trace amounts of petrified wood that indicate a northwest source terrane. This unit is the upper Santa Fe hydrostratigraphic unit (USF, fig. 9).

Sediments that underlie the disconformable upper Santa Fe gravelly beds below $97 \mathrm{ft}$ (29.6 m) depth contain red and reddish brown clay beds, characteristic of the Middle Red Member of the Santa Fe Group of Kelley (1977) and derived from western or northwestern fluvial-lacustrine source areas of the ancestral Rio Puerco and Jemez River. The sequence of interbedded sand, silty sand, silty clay, and clay in the drill hole from $97 \mathrm{ft}$ to $1500 \mathrm{ft}(29.6-457.2 \mathrm{~m})$ is correlated tentatively with the middle unit of the Santa Fe Group.

Hawley (1995) and Connell and others (1998) interpret the sandy interval between $97 \mathrm{ft}$ and $441 \mathrm{ft}$ (29.6-134.4 m) to be transitional between the overlying coarse-grained gravelly beds and underlying clayey strata. They correlate this sandy interval with the lower part of the Sierra Ladrones Formation, and include it in the basal zone of the upper Santa Fe. 


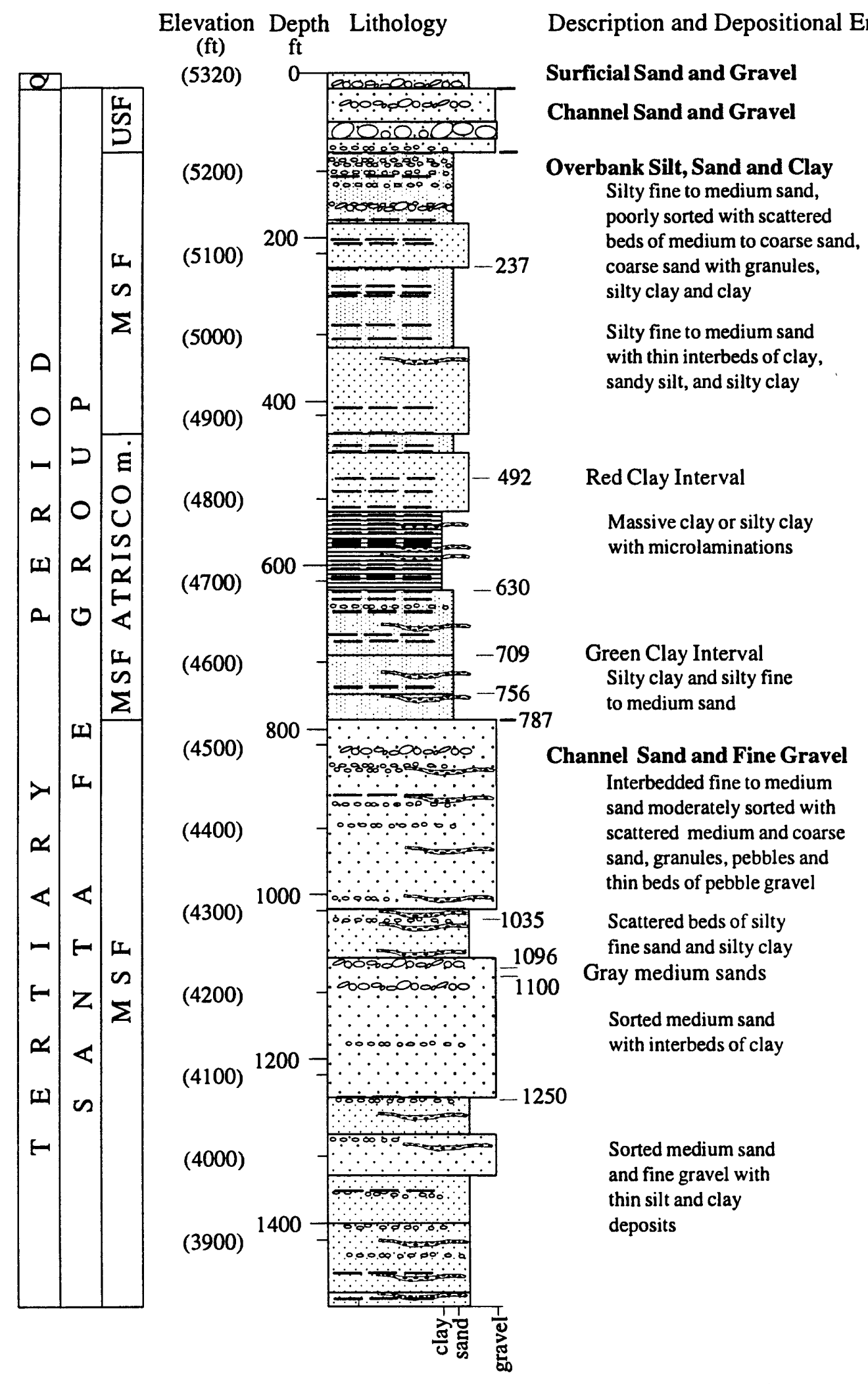

Figure 7. Preliminary lithostratigraphy and depositional environments of sediments in the 98th Street core. Age symbol Q represents Quaternary Period; symbol USF represents upper unit of the Santa Fe Group; symbol MSF represents middle unit of the Santa Fe Group; MSF Atrisco m. is the Atrisco member of the middle unit of the Santa Fe Group. 
The upper part of the sandy zone, in the interval 97-237 ft (29.6-72.2 m), consists of interbedded pale brown, brown, and light brown silty, fine-to- medium sand, poorly sorted, with scattered beds of medium to coarse sand, coarse sand with granules, silty clay and clay. Massive reddish brown clay beds, $0.5-1.0 \mathrm{ft}$ $(15-30.5 \mathrm{~cm})$ thick, were sampled at $124.4 \mathrm{ft}(37.9$ $\mathrm{m}), 178 \mathrm{ft}(54.2 \mathrm{~m})$, and $208 \mathrm{ft}(63.4 \mathrm{~m})$. The lower part of the sandy zone, at 237-441 ft (72.2-134.4 m) depth, is somewhat finer grained than the upper part, and consists of interbedded thin beds of clayey and sandy silt, silty fine sand, brown silty clay, red to reddish brown clay, and scattered beds of medium sand. Depositional environments for the zone are inferred to include fluvial interchannel overbank areas, small secondary stream channels, and ponded areas.

The 441-787 ft (134.4-239.9 $\mathrm{m})$ interval is correlated with the Atrisco member (informal) of Connell and others (1998). It consists of thin-bedded fine sand, poorly sorted silty sand, and laminated silt, fine sand, and clay. Core samples and geophysical logs demonstrate that this interval is distinctly finergrained than overlying and underlying beds, and contains numerous and relatively thick sequences of red to reddish brown clay, and silt in sets of laminated beds commonly $<2 \mathrm{ft}(0.61 \mathrm{~m})$ thick, and as much as $4.45 \mathrm{ft}(1.36 \mathrm{~m})$ thick. These laminated sets locally preserve delicate microlaminations of clay and silt, but most beds contain massive clay or silty clay. A distinctive zone between $709 \mathrm{ft}$ and $756 \mathrm{ft}$ (216.1$230.4 \mathrm{~m}$ ) appears olive green, consisting of light olive brown to dark grayish brown silty clay, and silty fine to medium sand.

The entire upper part of the middle Santa Fe unit $(97-787 \mathrm{ft}$ [29.6-239.9 m]) is inferred to contain a series of laterally extensive fluvial overbank deposits that are contained locally in $3.3-33 \mathrm{ft}-(1-10 \mathrm{~m})$ thick upward-fining units. The overbank deposits accumulated in shallow abandoned channels or backswamp ponds, the extent of which may have been related to syndepositional fault scarps that controlled the location of the main river channel, tributary stream channels, and overbank flats (Stone and Allen, 1998). An alternative playa-lake origin for these fine-grained beds seems inconsistent with lack of evidence, such as evaporite minerals, desiccated mud-flat polygons, eolian concentration of dried clay pellets, deltaic foreset strata, ripple-drift cross laminations, and wave segregated and sorted sediment in wavy bedforms (J. Smoot, USGS, personal comm. 1998). The upper part of the middle Santa Fe unit (97-787 ft [29.6$239.9 \mathrm{~m}$ ) ) constitutes the middle Santa Fe hydrostratigraphic unit MSF-2/3 (fig.9).

The lower section of the middle Santa Fe unit, 787-1500 ft (239.9-457.2 m) depth, contains an upper sequence of moderately sorted medium sand, and a lower sequence of sand and interbedded silt and clay beds. The upper sequence, which extends from $787 \mathrm{ft}$ to $1,246 \mathrm{ft}(239.9-381 \mathrm{~m})$ depth, consists chiefly of brown to dark brown, interbedded fine to medium sand, moderately sorted and without silt matrix, with scattered medium and coarse sand beds, granules and pebbles, and thin beds of pebble gravel. Scattered beds of silty fine sand and silty clay were sampled in the interval 1,035-1,096 ft (315.4-334 m). At the depth of $1,096 \mathrm{ft}(334 \mathrm{~m})$, the color changes notably to lower chroma values, typically grayish brown, and grain size increases slightly with the inclusion of more medium sand beds. Sorted medium sands also are common below the depth of $1,096 \mathrm{ft}$, where these coarse beds are interbedded with scattered clay beds. Depositional environments for the $787 \mathrm{ft}$ to $1,246 \mathrm{ft}$ (239.9-381 m) interval include fluvial secondary stream channels and overbank areas. Gravel clasts include distinctive chert, pink granite, and other materials derived from northeastern and northern fluvial source areas. The lower part of the middle Santa Fe, below 1,246 ft (381 m) depth, contains sorted medium sand and fine gravel, and also numerous, thin silt and clay deposits, probably reflecting sedimentation in overbank areas. The entire lower part of the middle Santa Fe unit from $787 \mathrm{ft}$ to 1,500 $\mathrm{ft}(239.9-457.2 \mathrm{~m})$ forms the middle Santa Fe Hydrostratigraphic unit MSF-4 (fig.9).

The precise age of the deposits in the 98th Street core hole cannot be established with current data. At the top, the surficial valley-border alluvial and eolian deposits postdate erosion into the early Quaternary Llano de Alburquerque geomorphic surface. The alluvial deposits may be as old as the Tercero Alto terrace deposits east of the drill site (Bryan, 1938), possibly middle Pleistocene. The eolian deposits may range in age from middle Pleistocene to late Holocene. The age of the Llano de Alburquerque geomorphic surface is constrained by calibrated, minimalage estimates of its Stage IV carbonate soil of $>500$ 
KA to perhaps $\geq 1$ MA (Machette and others, 1997), which are therefore minimal constraining ages of the upper Santa Fe unit in which the soil developed. No datable tephra or macrofossils were found in our field examination of the core so that the age of any part of the section remains undefined.

The fluvial gravelly beds of the upper Santa Fe unit regionally are correlated with an integrated, through-flowing river system that was established in the Rio Grande rift basins in Early Pliocene time, $\geq 4.5$ MA (Lozinsky and others, 1991, Chapin and Cather, 1994). The age range of the upper Santa $\mathrm{Fe}$ is thus limited to $\geq 4.5-\geq 1 \mathrm{MA}$, but its disconformable basal contact and cut-and-fill depositional processes suggest that its basal sediments could be $<4.5 \mathrm{MA}$. The true age of the Llano de Alburquerque geomorphic surface may be considerably older than $1 \mathrm{MA}$, and the upper unit of the Santa Fe may be wholly Pliocene.

The age of the middle Santa Fe unit is estimated from regional correlation and preliminary magneticpolarity data. At Loma Colorado, $13.7 \mathrm{mi}(22 \mathrm{~km})$ north-northeast of the 98th Street site, a sequence of sandy light brown and reddish brown beds that directly underlie gravel deposits of the upper Santa Fe unit (S.F. Personius, USGS, pers. communication, 1997) reportedly contain Late Miocene (Hemphellian) fauna (S.G. Lucas, pers. communication, 1997; 4.68.9 MA, Woodburne and Swisher, 1995).

Preliminary paleomagnetic polarity data from the 98 th Street core (Hudson and others, 1998) indicate that the middle Santa Fe unit below $97 \mathrm{ft}(29.5 \mathrm{~m})$ dominantly preserves sequences with normal magnetic polarity. These and few, short reversal sequences in the core may correlate with closely spaced normal and reversed magnetic chrons 5.9-8.3 MA in age (chrons C3An.1n-C4r.1n; Berggren and others, 1995) or with other, older, normal chrons. No thick paleosols or major unconformities were recovered in the core. It is likely that the cored interval may span less than a few million years.

\section{COMPARISON AND CORRELATION OF THE 98th STREET WELL WITH NEARBY WELLS}

The core samples collected from the 98th Street core hole and the extensive set of geophysical logs provide unprecedented opportunities to extrapolate stratigraphic correlations to other wells in the central part of the Albuquerque basin. The 98th Street core hole is the only well in the basin that provides this type of integrated lithologic, sedimentologic, and geophysical information and it provides the critical reference collection. Other water supply wells, monitoring wells, and exploratory holes in the basin are characterized only by drillers' lithologic logs, limited suites of geophysical logs, and some cuttings collections. The unique information obtained at the 98th Street site provides the basis to make comparisons and revisions to the less complete records for adjoining wells. The correlations described below give reliable evidence of critical sedimentologic and structural relationships among the drilled sections that could only be speculated prior to completion of the 98th Street core hole.

The locations of other deep wells and well fields in the area surrounding the 98th Street core hole are shown in figure 1. Figure 8 shows comparative electrical conductivity logs for the 98th Street core hole and six other nearby wells. Other logs and lithologic characteristics could also be displayed to illustrate the stratigraphic correlations, but the electrical logs are the only available, consistent, and most reliable data set for these wells.

The distinctive lithologic zone in the 98th Street hole between 441-787 ft (134.4-239.9 m), the Atrisco member of (Connell and others (1998), characterized by persistent red-brown clay is clearly identifiable in the electrical logs for the 98th Street well (fig. 8). The high clay content in this part of the section imparts an overall increase in electrical conductivity (indicated by the elevated baseline of the log trace), and the thicker beds are closely correlated with highconductivity spikes in the log signature. The bottom of the clay-rich zone is more sharply delimited than the top; the onset of clay deposition appears to have been rather abrupt, whereas interbedding with silt and sand is more gradual in the upper part of the zone. These same electrical characteristics are present in the conductivity logs for the surrounding wells, and provide the basis for our correlation of the Atrisco member throughout the subsurface of the Albuquerque metropolitan area (fig. 8; Allen and others, 1998; Connell and others,1998). This fine-grained unit is here recognized as a zone that separates the primary upper Santa Fe aquifer system utilized in 
water production in the Albuquerque, Paradise Hills, and Rio Rancho areas from older (middle) Santa Fe deposits. The only City of Albuquerque well that is screened almost completely in the lower coarsegrained interval (below $787 \mathrm{ft}[239.9 \mathrm{~m}]$ in the 98th Street core hole) is Don Well No. 1 (fig.1).

Figure 8 shows correlations of the interpreted base of the Atrisco member among the wells in the west-central Albuquerque basin. Faults mapped in the surface geology or interpreted from the highresolution aeromagnetic survey data (fig. 1; Grauch and others, 1998) account for several of the sharp offsets in the elevation of this Atrisco member. For example, nearly $450 \mathrm{ft}$ of displacement is indicated between the base of the Atrisco in the Don No. 1 well and the Don No. 2 well across the down-to-the-east fault that borders the fault block containing the 98th Street site. Similarly, about $500 \mathrm{ft}$ of displacement is indicated between the 98th Street well and the College No. 1 well across the eastern, down-to-theeast, bounding intrabasin fault (fig. 8).

\section{ESTIMATED HYDROGEOLOGIC CHARACTERISTICS}

Four hydrostratigraphic units that are based on the lithologic characteristics of the sediments and their correlation with lithofacies in the Middle Rio Grande basin summarize the hydrogeologic framework for the 98th Street site (fig. 9). The lithofacies have characteristic lithologic properties, geophysical signatures (fig. 3), and parameters that influence ground-water production (Haase and Lozinsky, 1992). Lithofacies are combined in hydrostratigraphic units that contrast in hydraulic conductivity and are extensive and mappable in the subsurface.

Three sets of estimated average horizontal hydraulic conductivities $(\mathrm{K})$ for lithologic units in the 98th Street core hole are shown in figure 9. The estimates in column A are based on the general hydrogeologic characteristics associated with the lithofacies of Hawley and Haase (1992). The estimates in column $\mathrm{B}$ are the assigned mean $\mathrm{K}$ values used in the ground-water flow model layers of Kernodle and others (1995), which were based on the previous interpretations of the regional subsurface geology. The estimates of hydraulic conductivity in column C are based on the empirical relationships of permea- bility and grain size of noncemented samples of the Santa Fe Group (Detmer, 1995, fig. 3), in which hydraulic conductivity is estimated from values of $D_{10}$ of the grain size distribution for each sample. In figure 9, an empirical $\mathrm{K}$ value and inferred range of values are estimated from the median and range of $D_{10}$ values of the modal grain size in each lithologic unit in the 98th Street core. The ranges of values, in parentheses, are estimated from the variability of data points in the original analysis (Detmer, 1995, fig. 3). In column $\mathrm{D}$, the estimated $\mathrm{K}$ values for hydrostratigraphic units are based on $\mathrm{K}$ values of the included lithologic units normalized to lithologic-unit thicknesses.

The estimated empirical values for $\mathrm{K}$ emphasize a previously unknown contrast in estimated hydraulic conductivity in the lowest two hydrostratigraphic units. Unit MSF-2/3 is correlated with the upper part of the middle Santa Fe Group (the Atrisco member and overlying sandy zone), and is composed chiefly of thin-bedded fine sand, poorly sorted silty sand, and laminated silt, fine sand and clay. The unit contains more than 30 beds of red clay, and thick sequences of clayey silt. This unit, which includes the silt-clay sequence in lithologic unit $12,96 \mathrm{ft}(29.2 \mathrm{~m})$ thick, is inferred to be a laterally extensive (fig. 8) barrier to vertical ground-water flow in the area. The underlying unit MSF-4 comprises fluvial channel-fill sediments of the ancestral Rio Grande river system, including the thick sequences of moderately wellsorted medium sand in lithologic units 4,6 , and 8 . Bedding connectivity within these units is inferred to be high, but the lateral continuity of individual lithofacies or the entire hydrostratigraphic unit is not known (fig. 8). Furthermore, estimated $\mathrm{K}$ values from combinable magnetic resonance data generally support the trends of empirical $\mathrm{K}$ values and the vertical extent of units with intermediate values of 17 $\mathrm{ft} /$ day (fig. 9). However, these data indicate that the estimates of $170 \mathrm{ft} /$ day in lithologic units 4,6 , and 8 may be too high by a factor of 4-5, possibly due to poor sorting, cementation, or compaction of the sediments at depths below $800 \mathrm{ft}(243.8 \mathrm{~m})$. Further sedimentologic and hydraulic analyses of the core samples are needed to assess these differences as well as the accuracy of the geophysical methods.

Laboratory determination of hydraulic conductivity values of selected recompacted sandy samples 


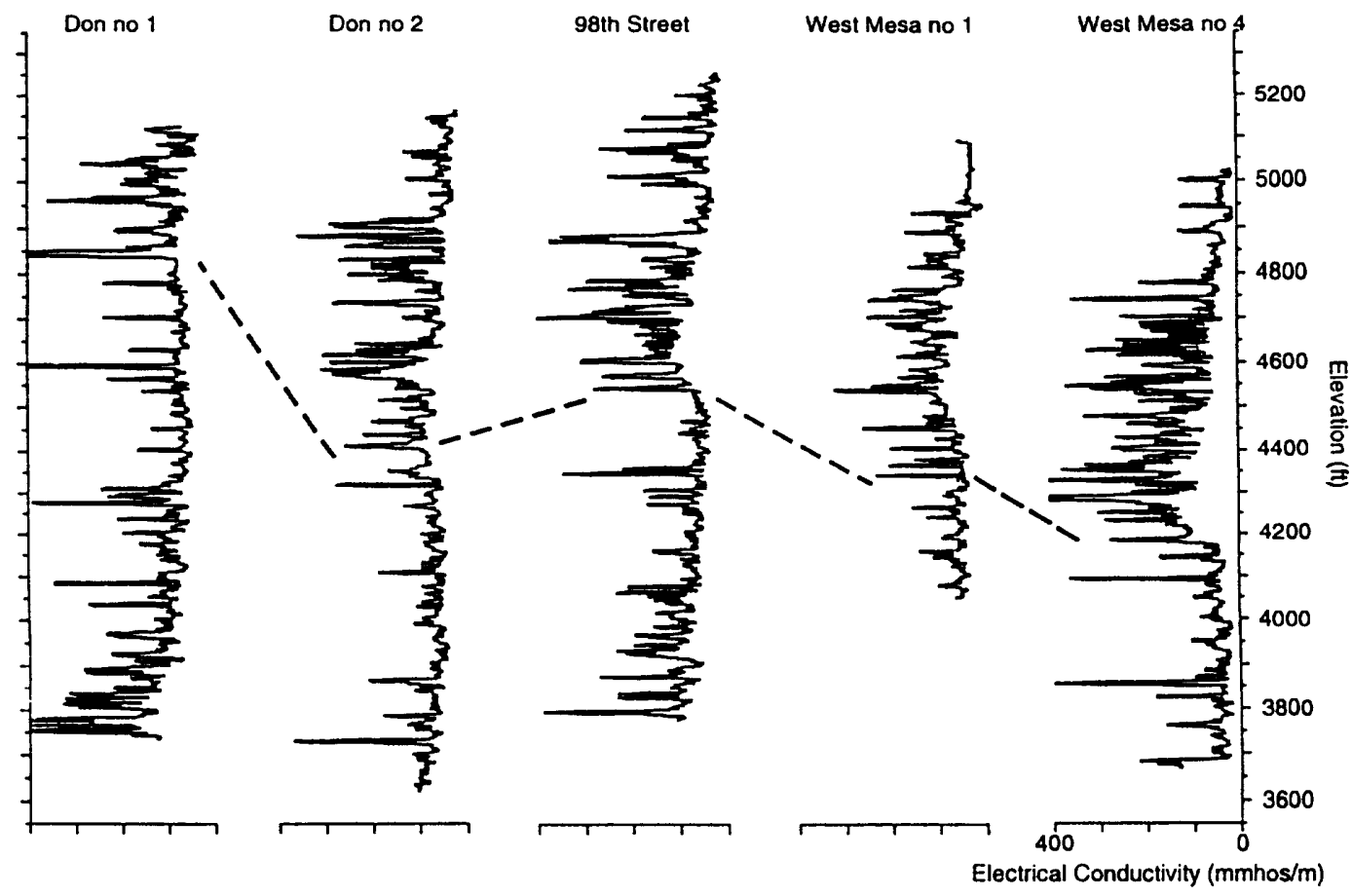

South

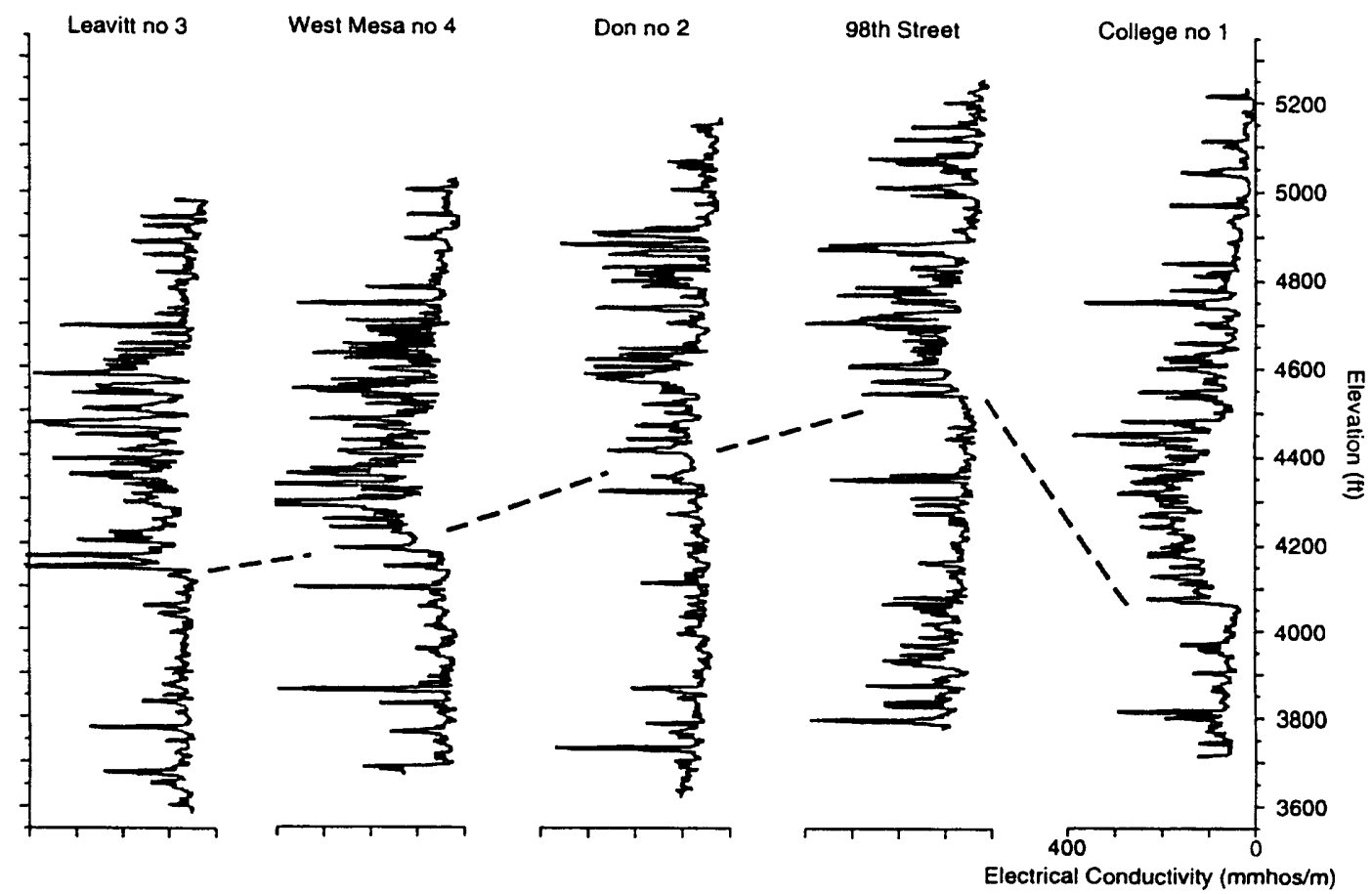

Figure 8. Correlations of the middle Santa Fe transition zone (Atrisco member) among wells in the College, West Mesa, and Don well fields (see fig. 1 for well locations). 
and core samples from the upper part of the cored interval are shown in table 5. Estimates of $\mathrm{K}$ based on the empirical relationship of $\mathrm{K}$ and $\mathrm{D}_{10}$ of the particle-size distribution (Detmer, 1995) are included in the table for comparison. For clayey, fine-grained samples, $\mathrm{K}$ was determined from consolidation tests on core samples, and $\mathrm{K}$ values are thus values for vertical conductivity, $\mathrm{K}_{\mathrm{v}}$. Results are shown for low and high consolidation (effective stress) loads (10$1000 \mathrm{kPa}$ [1.45-145 psi]). Plots of logarithmic $\mathrm{K}_{\mathrm{V}}$ and logarithmic vertical effective stress generally show strong linear relationships over the range of load values (Haneberg and others, 1998). These relationships show decrease in $\mathrm{K}_{\mathrm{v}}$ with decrease in void ratio (porosity) by two to four orders of magnitude ( $\mathrm{ft} / \mathrm{day}$ ) (table 5). For sandy, coarse-grained samples, $\mathrm{K}$ was determined from permeameter tests that used disaggregated, recom-pacted samples. Results of these tests show well developed linear relationships between logarithmic confining pressure and logarithmic K. However, the hydraulic conductivity values of the predominantly sandy samples were less sensitive to changes in stress than were the clayey samples tested in the consolidometer (table 5).

All laboratory data show no apparent relationship between $\mathrm{K}$ and geotechnical properties, except density (porosity). The test results show that hydraulic conductivity values of all sediments of the upper Santa Fe unit are sensitive to the magnitude of effective stress corresponding to $3.3 \mathrm{ft}$ to $330 \mathrm{ft}(1-100 \mathrm{~m})$ of depth. The fine-grained sediments appear to be more sensitive to changes in stress, varying by as much as four orders of magnitude. Comparison of laboratory tests of sandy, coarse-grained samples at high confining pressures with the empirical $\mathrm{K}$ values based on the $D_{10}$ grain size shows that laboratory values of $K$ are lower than minimum empirical values by $1-3$ orders of magnitude. This discrepancy most likely derives in part from the different methods and time periods in which $\mathrm{K}$ was measured. It also may be attributed to differences in porosity (sorting and matrix, consolidation fabric, cementation) among tests conducted on in situ beds at the surface (Detmer) and poorly sorted channel samples from the vadose and saturated zones in the core. Comparison of minimum laboratory and empirical $\mathrm{K}$ values from four core samples with calculated $\mathrm{K}$ values derived from the CMR geophysical log (fig.4) shows further discrepencies (table 6).
For fine-grained samples, the CMR $\mathrm{K}$ values are more than $0-2$ orders of magnitude greater than the limiting $\mathrm{D}_{10}$ estimate for average horizontal conductivity. The CMR values are 3-6 orders of magnitude greater than the laboratory $\mathrm{K}_{\mathrm{v}}$ values, which in turn are 2-4 orders of magnitude less than the empirical $K$ values. These relationships indicate possible ratios of $\mathrm{k}_{\mathrm{v}} / \mathrm{k}_{\mathrm{h}}$ of $\geq 9 \times 10^{4}$ (unit 16) to $\geq 1.4 \times 10^{4}$ to $5.8 \times 10^{7}$ (unit 13). For unit 13, it appears that the relatively high calculated CMR $\mathrm{K}$ values may be based on high porosity values that do not reflect poor sorting, consolidation, or cementation. Additional analysis of fine-grained sediments could extend the estimated range of values of Detmer (1995) and could provide another constraint on $\mathrm{K}$ values calculated from geophysical data.

At the 98th Street site (row 122, column 35 of the ground-water flow model of Kernodle and others, 1995), previous estimates of average hydraulic conductivity for model layers 1-8 was $15 \mathrm{ft} /$ day, and 4 $\mathrm{ft} /$ day in model layers 9 and 10, reflecting the inferred downward fining and progressive consolidation or cementation of the middle Santa Fe deposits. The preliminary results of our analysis of the 98th Street core indicate that a downward-fining and resultant downward lowering of $\mathrm{K}$ is applicable in units 9-17 in the $409 \mathrm{ft}(124.6 \mathrm{~m})$ of this aquifer that is located below the water table (at $378 \mathrm{ft}$ [115.2 m] depth). From depths of 787 to $1,483 \mathrm{ft}(239.9-452 \mathrm{~m})$, however, empirical $\mathrm{K}$ values range from $17 \mathrm{ft} /$ day to 170 $\mathrm{ft} /$ day (5-38 ft/day, CMR data) in a sequence of lithologic units that are chiefly noncemented medium sand. Stratigraphic correlations (fig. 8; Haase, 1992, p. V-13) indicate that similar trends in lithostratigraphy and hydrogeologic characteristics of this zone have wide lateral extent over a significant area of western Albuquerque, and may represent a potential ground-water production zone whose characteristics should be further investigated. For example, as noted by Haase (1992, p. V-15), deeper wells in the College and nearby well fields have potential for substantially increased production from correlatives of the lower coarse-grained unit. However, with discrepancies in estimated or measured $K$ values of as much as three orders of magnitude ( $\mathrm{ft} / \mathrm{day}$, tables 5 , 6), additional field tests of horizontal hydraulic conductivity from isolated lithofacies, and further tests of core samples and geophysical techniques are needed to supply this basic hydraulic parameter to future studies of the Santa Fe Group aquifer. 

A.
B.
C.
D.

Elevation Depth Lithologic Lithofacies Ground-water CMR Permeability Empirical Hydrostratigraphic

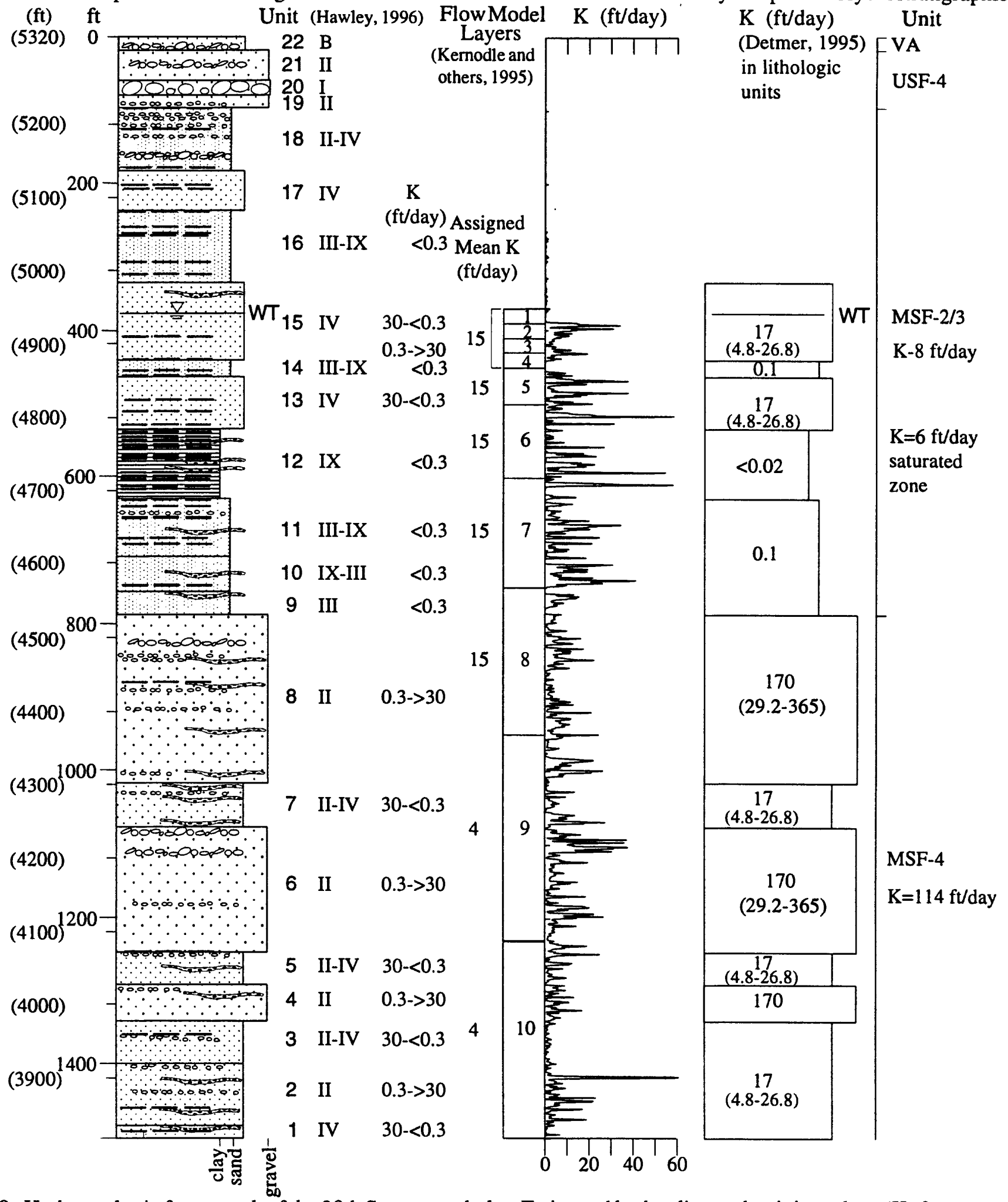

Figure 9. Hydrogeologic framework of the 98th Street core hole. Estimated hydraulic conductivity values $(\mathrm{K})$ for lithologic units are based on: A) the general hydrogeologic characteristics associated with the lithofacies of Hawley and Haase (1992); B) the assigned mean K in the ground-water flow model of Kernodle and others (1995); C) the empirical relationship of permeability and grain size $\left(d_{10}\right)$ of Detmer (1995). Estimated $\mathrm{K}$ values for hydrostratigraphic units $(\mathrm{D})$ are based on $\mathrm{K}$ values for lithologic units normalized to proportional lithologic-unit thicknesses. 
Table 5. Measured and computed hydraulic conductivity values for samples from the 98th Street core.

\begin{tabular}{|c|c|c|c|c|}
\hline $\begin{array}{l}\text { Coarse-grained } \\
\text { samples }\end{array}$ & Grain size $^{1}$ & $\begin{array}{l}\mathrm{K}, 10 \mathrm{kPa} \text { confining } \\
\text { pressure, } \mathrm{ft} / \text { day }\end{array}$ & $\begin{array}{l}\mathrm{K}, 1000 \mathrm{kPa} \text { confining } \\
\text { pressure, } \mathrm{ft} / \mathrm{day}\end{array}$ & $\begin{array}{l}K \text { range based on } \\
D_{10}, f t / d a y\end{array}$ \\
\hline Unit 18 (Drive 14B, 98') & Fine sand & $6.49 \times 10^{-1}$ & $3.41 \times 10^{-2}$ & $1.3 \times 10^{1}-1.5 \times 10^{2}$ \\
\hline Unit 18 (Drive17D, 117') & Medium sand & 3.74 & $6.8 \times 10^{-1}$ & $7.4-1.3 \times 10^{2}$ \\
\hline Unit $18\left(124^{\prime}\right)$ & Coarse sand & & $4.24 \times 10^{-1}$ & $5.5-9.0 \times 10^{1}$ \\
\hline Unit 18 (Drive 23A, 147') & Medium sand & 2.71 & $4.70 \times 10^{-1}$ & $5.5-8.2 \times 10^{1}$ \\
\hline Unit 18 (Drive 25B, 162') & Coarse sand & $1.49 \times 10^{-1}$ & $9.39 \times 10^{-2}$ & $8.2 \times 10^{-1}-1.1 \times 10^{1}$ \\
\hline Unit 18 (Drive 27'B, 173') & Silty fine sand & 2.71 & $4.70 \times 10^{-1}$ & $7.4-1.3 \times 10^{2}$ \\
\hline Unit (Drive 31B, ') & Silty fine sand & $7.81 \times 10^{-1}$ & $3.74 \times 10^{-1}$ & $5.5-8.2 \times 10^{1}$ \\
\hline Unit 17 (Drive 33A, 204') & Coarse sand & $7.12 \times 10^{-1}$ & $5.40 \times 10^{-2}$ & $5.5-8.2 \times 10^{1}$ \\
\hline Unit 16 (Drive 38A, 244') & Silty fine sand & $1.01 \times 10$ & $1.21 \times 10^{-2}$ & $1.6-3.6 \times 10^{1}$ \\
\hline Unit 16 (Drive 55B, 335') & Medium sand & $7.81 \times 10^{-1}$ & $2.83 \times 10^{-1}$ & $7.4-1.3 \times 10^{2}$ \\
\hline $\begin{array}{l}\text { Fine-grained } \\
\text { samples }\end{array}$ & Grain size $^{2}$ & $\begin{array}{l}\mathrm{K}_{\mathrm{v}}, 10 \mathrm{kPa} \\
\text { confining pressure }\end{array}$ & $\begin{array}{l}\mathrm{K}_{\mathrm{v}}, 1000 \mathrm{kPa} \\
\text { confining pressure }\end{array}$ & $\begin{array}{l}K \text { range based on } \\
D_{10}, \text { ft/day }\end{array}$ \\
\hline Unit 18 ( Drive $20,126^{\prime}$ ) & Clay & $2.77 \times 10^{-3}$ & $1.42 \times 10^{-6}$ & $<2 \times 10^{-2}$ \\
\hline Unit 18 (Drive $24 \mathrm{~A}, 150^{\prime}$ ) & Clayey, silty sand & $2.71 \times 10^{-1}$ & $1.36 \times 10^{-4}$ & $1 \times 10^{-1}$ \\
\hline Unit 17 (Drive 37A, 228') & Silty clay & $1.30 \times 10^{-3}$ & $2.25 \times 10^{-6}$ & $<2 \times 10^{-2}$ \\
\hline Unit 16 (Drive 40C, 256') & Coarse sand & $2.75 \times 10^{-2}$ & $3.37 \times 10^{-5}$ & \\
\hline Unit 16 (Drive 40A, 251') & Silty clay & $1.33 \times 10^{-1}$ & $1.33 \times 10^{-4}$ & $<2 \times 10^{-2}$ \\
\hline Unit 16 (Drive $4^{4}, 256^{\prime}$ ) & Silty clay & $4.10 \times 10^{-2}$ & $6.49 \times 10^{-6}$ & $<2 \times 10^{-2}$ \\
\hline Unit 16 (Drive $5^{4}, 314^{\prime}$ ) & Silty clay & $4.93 \times 10^{-2}$ & $2.25 \times 10^{-5}$ & $<2 \times 10^{-2}$ \\
\hline Unit 13 (Drive 90C, 507') & Silty clay & $1.87 \times 10^{-3}$ & $2.83 \times 10^{-6}$ & $<2 \times 10^{-2}$ \\
\hline Unit 13 (Drive 93B, 522') & Silty clay & $9.17 \times 10^{-2}$ & $3.49 \times 10^{-4}$ & $<2 \times 10^{-2}$ \\
\hline
\end{tabular}

${ }^{1}$ Grain size from Haneberg and others (1998b); ${ }^{2}$ Grain size from Appendix A. ${ }^{3}$ Value from regression analysis of Haneberg and others (1998a)

Table 6. Laboratory, empirical, and geophysical hydraulic conductivity values for four samples from the 98th Street core .

\begin{tabular}{|l|l|l|l|l|}
\hline Sample & Grain size & $\begin{array}{l}\text { Laboratory K, } \\
\text { 1000 kPa confining } \\
\text { pressure, ft/day }\end{array}$ & $\begin{array}{l}\text { K, range based } \\
\text { on } \mathrm{D}_{10}, \mathbf{f t} / \text { day }\end{array}$ & $\begin{array}{l}\text { K, CMR } \\
\text { geophysical log } \\
\text { ft/day- }\end{array}$ \\
\hline Unit 16(335') & Medium sand & $\mathrm{K} 2.83 \times 10^{-1}$ & $7.4-1.3 \times 10^{2}$ & $3.67 \times 10^{-2}$ \\
\hline Unit 16(314.3') & Silty clay & $\mathrm{K}_{\mathrm{v}} 2.25 \times 10^{-5}$ & $<2 \times 10^{-2}$ & $2.40 \times 10^{-2}$ \\
\hline Unit 13(507.2') & Silty clay & $\mathrm{K}_{\mathrm{v}} 2.83 \times 10^{-6}$ & $<2 \times 10^{-2}$ & 4.89 \\
\hline Unit 13(522.3') & Silty clay & $\mathrm{K}_{\mathrm{v}} 3.49 \times 10^{-4}$ & $<2 \times 10^{-2}$ & 3.68 \\
\hline
\end{tabular}

${ }_{1}^{1}$ Nominal values of nearest half-foot vertical intervals 


\section{REFERENCES CITED}

Allen, B.D., Connell, S.D., Hawley, J.W., and Stone, B.D., 1998, Core drilling provides information about Santa Fe Group aquifer beneath Albuquerque's west side: New Mexico Geology, v. 20, No. 1, p. 8-13.

American Society for Testing and Materials (ASTM), 1995, Standard Practice for Description and Identification of Soils (Visual-Manual Procedure), Designation D2488-95: American Soil and Rock; Dimension Stone; Geosynthetics; Philadelphia, PA, p. 320-332.

Bartolino, J. R. [ed.], 1997, U.S. Geological Survey Middle Rio Grande Basin Study--Proceedings of the First Annual Workshop, Denver, Colorado, November 12-14, 1996: U.S Geological Survey Open-File Report 97-116, 91 p.

Berggren, W.A., Kent, D.V., Swisher, C.C., III, and Aubrey, M.P., 1995, A revised Cenozoic geochronology and chronostratigraphy: SEPM (Society for Sedimentary Geology) Special Publication No., 54, p.130-212.

Bjorklund, L.J., and Maxwell, B.W., 1961, Availability of ground water in the Albuquerque area, Bernalillo and Sandoval Counties, New Mexico: New Mexico State Engineer Technical Report 21, 117 p.

Bryan, Kirk, 1909, Geology of the vicinity of Albuquerque: University of New Mexico Bulletin 51, Geological Series, v. 3, no.1, 24 pp.

1938, Geology and ground-water conditions of the Rio Grande depression in Colorado and New Mexico: in U.S. Natural Resources Committee, regional planning, part VI--the Rio Grande Basin in Colorado, New Mexico, and Texas, 1936-37: U.S. Government Printing Office, v.1, pt 2, p.197-225.

Bryan, Kirk, and McCann, F.T., 1937, The Ceja del Rio Puerco--A border feature of the Basin and Range Province in New Mexico, I. Stratigraphy and structure: Journal of Geology, v. 45, p. 801-828.
Chapin, C.E., and Cather, S.M., 1994, Tectonic setting of the axial basins of the northern and central Rio Grande Basin, New Mexico: in G.R. Keller and S.M. Cather [eds.], Basins of the Rio Grande Rift -Structure, stratigraphy, and tectonic setting; Geological Society of America Special Paper 291, p. 5-25.

Connell. S.D., Allen, B.D., and Hawley, J.W., in press, Subsurface stratigraphy, structure, and hydrogeologic framework of the Santa Fe Group from borehole geophysical logs, northern Albuquerque basin, New Mexico: in J.L. Slate, [ed.], U.S. Geological Survey Middle Rio Grande Basin Study-Proceedings of the Second Annual Workshop, Albuquerque, New Mexico, February 10-12, 1998; U.S. Geological Survey Open-File Report 98-337, $111 \mathrm{p}$.

Connell. S.D., Allen, B.D., and Hawley, J.W., 1998, Subsurface stratigraphy of the Santa Fe Group from borehole geophysical logs, Albuquerque area, New Mexico: New Mexico Geology, v. 20, No. 1, p. 2-7.

Detmer, D.M., 1995, Permeability, porosity, and grain-size distribution of selected Pliocene and Quaternary sediments in the Albuquerque Basin: New Mexico Geology, v. 17, No. 4, p. 79-87.

Folk, R.L., 1980, Petrology of Sedimentary Rocks: Hemphill, Austin, Texas, 184 p.

Grauch, V.J.S., in press, Expression of faults in highresolution aeromagnetic data near Albuquerque, New Mexico--preliminary results; in J.L. Slate, [ed.], U.S. Geological Survey Middle Rio Grande Basin Study-Proceedings of the Second Annual Workshop, Albuquerque, New Mexico, February 10-12, 1998; U.S. Geological Survey Open-File Report 98-337, $111 \mathrm{p}$.

Haase, C.S., 1992, Borehole geophysical data: in J.W. Hawley and C.S. Haase, compilers, Hydrogeologic framework of the northern Albuquerque basin; New Mexico Bureau of Mines and Mineral Resources, Open-File Report 387, p. V-1--V-18. 
Haase, C.S, and Lozinsky, R.P., 1992, Estimation of hydrologic parameters: in J.W. Hawley and C.S.

Haase, compilers, Hydrogeologic framework of the northern Albuquerque basin; New Mexico Bureau of Mines and Mineral Resources, Open-File Report 387, p. VI-1--VI-3.

Haneberg, W.C., Gomez, P., Gibson, A., and Allred, B., 1998a, Preliminary measurements of stressdependent hydraulic conductivity of Santa Fe Group aquifer system sediments from the 98 th Street corehole, Albuquerque, New Mexico: New Mexico Geology, v. 20, No. 1, p. 14-20.

W. Haneberg, B. Allred, P. Swearingen, and A. Gibson, 1998b, Consolidation test results, triaxial permeability values, and particle size distributions, 98th Street ground water monitoring well, Albuquerque, New Mexico; New Mexico Bureau of Mines and Mineral Resources, Open-File Report 436, $126 \mathrm{p}$.

Hawley, J.W., 1996, Hydrologic framework of potential recharge areas in the Albuquerque basin, central New Mexico, in J.W. Hawley and T.M. Whitworth [eds.], Hydrology of potential recharge areas and hydrogeochemical modeling of proposed artificial-recharge methods in basin- and valley-fill aquifer systems, Albuquerque Basin, New Mexico; New Mexico Bureau of Mines and Mineral Resources Open-File Report 402-D, Chapter 1, p. 1-71.

Hawley, J.W., and Haase, C.S., compilers, 1992, Hydrogeologic framework of the northern Albuquerque basin: New Mexico Bureau of Mines and Mineral Resources, Open-File Report 387, 74 p., 8 appendices.

Hawley, J.W., Haase, C.S., and Lozinsky, R.P., 1995, Hydrogeologic framework of the northern Albuquerque Basin: in Ortega-Klett [ed.], The water future of Albuquerque and middle Rio Grande Basin; New Mexico Water Resources Research Institute, Technical Report No. 290, p. 37-55.

Heywood, C.E., 1992, Isostatic residual gravity anomalies in New Mexico: U.S. Geological Survey Water Resources Investigations Report 91-4065, 27 p.
Hudson, Mark, Mikolas, Marlo, Allen, B.D., and Geissman, J., in press, Paleomagnetic and rock magnetic studies of the upper Santa Fe Group; goals and preliminary results: in J.L. Slate, [ed.], U.S. Geological Survey Middle Rio Grande Basin Study-Proceedings of the Second Annual Workshop, Albuquerque, New Mexico, February 10-12, 1998; U.S. Geological Survey Open-File Report 98-337, $111 \mathrm{p}$.

Kaeler, C.A., 1990, Lithology of basin-fill deposits in the Albuquerque-Belen basin, New Mexico: U.S. Geological Survey Water Resources Investigations Report 89-4162, 14 p.

Kelly, V.C., 1977, Geology of Albuquerque basin, New Mexico: New Mexico Bureau of Mines and Mineral Resources Memoir 33, 60 p.

Kernodle, J.M., McCada, D.P., and Thorn, C.R., 1995, Simulation of ground-water flow in the Albuquerque basin, central New Mexico, 1901-1994, with projections to 2020: U. S. Geological Survey Water Resources Investigations Report 94-4251, 114 p.

Keys, W.S., 1989, Borehole geophysics applied to groundwater investigations: U.S. Geological Survey Techniques of Water-Resources Investigations, Chapter E2, Book 2, 150 p.

Lambert, P.W., 1968, Quaternary stratigraphy of the Albuquerque area, New Mexico: Albuquerque, University of New Mexico, Unpublished Ph.D. Dissertation, 329 p.

Large, Elizabeth, 1995, Miocene and Pliocene sandstone petrofacies of the northern Albuquerque basin, New Mexico: Los Angeles, University of California at Los Angeles, Unpublished M.S. Thesis, $113 \mathrm{p}$.

Lozinsky, R.P, 1988, Stratigraphy, sedimentology, and sand petrology of the Santa Fe Group and preSanta Fe Tertiary deposits in the Albuquerque basin, central New Mexico: Socorro, New Mexico Institute of Mining and Technology, Unpublished Ph.D. Dissertation, 298 p. 
Lozinsky, R.P, 1994, Cenozoic stratigraphy, sedimentology, and depositional history of the Albuquerque basin, central New Mexico: in G.R. Keller and S.M. Cather [eds.], Basins of the Rio Grande Rift -- Structure, stratigraphy, and tectonic setting; Geological Society of America Special Paper 291, p. 73-81.

Lozinsky, R.P., and Hawley, J.W., 1992, Geologic setting of the Albuquerque Basin, in J.W. Hawley and C.S. Haase, C.S., compilers, Hydrogeologic framework of the northern Albuquerque basin: New Mexico Bureau of Mines and Mineral Resources, Open-File Report 387, p. II-1 to II-7.

Lozinsky, R.P., Hawley, J.W., and Love, D.W., 1991, Geologic overview and Pliocene-Quaternary history of the Albuquerque Basin: New Mexico Bureau of Mines and Mineral Resources Bulletin 137, p. 157162.

Lozinsky, R.P., and Tetford, R.H., 1991, Geology and paleontology of the Santa Fe Group, Southwestern Albuquerque Basin, Valencia County, New Mexico: New Mexico Bureau of Mines and Mineral Resources, Bulletin 132, 35 p.

Machette, M.N., 1978a, Geologic map of the San Acacia quadrangle: U.S. Geological Survey Geologic Quadrangle Map GQ-1415, scale 1:24,000.

$1978 \mathrm{~b}$, Preliminary geologic map of the Socorro $1^{\circ} \times 2^{\circ}$ quadrangle, central New Mexico: U.S. Geological Survey Open-File Report 78-607, scale $1: 250,000$.

Machette, M.N., Long, Thomas, Bachman, G.O., and Timbel, N.R., 1997, Laboratory data for calcic soils in central New Mexico: background information for mapping Quaternary deposits in the Albuquerque basin: U.S. Geological Survey Open-File Report 96$722,60 \mathrm{p}$.

Mozley, P.S., Chamberlin, R, Gillentine, J.M., and Lozinsky, R.P., 1992, Petrologic data: in J.W. Hawley and C.S. Haase, compilers, Hydrogeologic framework of the northern Albuquerque basin; New Mexico Bureau of Mines and Mineral Resources, Open-File Report 387, p. IV-1-IV-17.
Munsell, 1975, Soil Color Charts; Munsell, Inc., Baltimore, MD, 22 p.

Pryor, W.A., 1973, Permeability-porosity patterns and variations in some Holocene sand bodies: American Association of Petroleum Geologists, Bulletin, v. 57, no. 1, p. 162-189.

Schlumberger Educational Services, 1989, Log Interpretation Principals/Applications: Schlumberger, Houston, Texas, 375 p.

Schlumberger Educational Services, 1991, Log Interpretation Charts: Schlumberger, Houston, Texas, $200 \mathrm{p}$.

Slate, J.L. [ed.], in press, U.S. Geological Survey Middle Rio Grande Basin Study--Proceedings of the Second Annual Workshop, Albuquerque, New Mexico, February 10-12, 1998; U.S. Geological Survey Open-File Report 98-337, 111 p.

Spiegel, Zane, 1961, Late Cenezoic sediments of the lower Jemez River region: New Mexico Geological Society Guidebook, 12th Field Conference, p. 132138.

Spiegel, Zane., and Baldwin, Brewster, 1963, Geology and water resources of the Santa Fe area, New Mexico: U.S. Geological Survey Water Supply Paper 1525, $258 \mathrm{p}$.

Stanton, M.R., Grimes, D.J., Sanzalone, R.F., and Sutley, S.S., in press, Sediment and ground-water geochemistry of the 98th Street drill core near Albuquerque, New Mexico: in J.L. Slate, [ed.], U.S. Geological Survey Middle Rio Grande Basin Study-Proceedings of the Second Annual Workshop, Albuquerque, New Mexico, February 10-12, 1998; U.S. Geological Survey Open-File Report 98-337, $111 \mathrm{p}$.

Stone, B.D., Allen, B.D., Mikolas, Marlo, Hawley, J.W., Johnson, Peggy, and M.R. Hudson, 1997, Preliminary Results from the 98th Street Stratigraphic Core Hole, Albuquerque, New Mexico: in J. R. Bartolino, [ed.], 1997, U.S. Geological Survey Middle Rio Grande Basin Study--Proceedings of the First 
Annual Workshop, Denver, Colorado, November 1214, 1996: U.S Geological Survey Open-File Report 97-116, p. 21-25

Stone; B.D., and Allen, B.D., in press, The 98th Street Core: Key to analysis of Santa Fe Group Stratigraphy and Hydrogeology in the Central Middle Rio Grande Basin: in J.L. Slate, [ed.], U.S. Geological Survey Middle Rio Grande Basin Study--Proceedings of the Second Annual Workshop, Albuquerque, New Mexico, February 10-12, 1998; U.S. Geological Survey Open-File Report 98-337, 111 p.

Thorn, C.R., 1997, Installation of ground-water monitoring wells in the Albuquerque, New Mexico, area: in J. R. Bartolino, [ed.], 1997, U.S. Geological Survey Middle Rio Grande Basin Study--Proceedings of the First Annual Workshop, Denver, Colorado, November 12-14, 1996: U.S Geological Survey Open-File Report 97-116, p. 56-58
Thorn, C.R., McAda, D.P., and Kernodle, J.M., 1993, Geohydrologic framework and hydrologic conditions in the Albuquerque basin, central New Mexico: U.S. Geological Survey Water Resources Investigatrions Report 93-4149, 106 p.

Woodburne, M.O., and Swisher, C.C., III, 1995, Land mammal high-resolution geochronology, intercontinental overland dispersals, sea level, climate, and vicariance: SEPM (Society for Sedimentary Geology) Special Publication No. 54, p.335-364. 


\section{APPENDIX A}

DESCRIPTIVE LITHOLOGIC LOG OF THE 98TH STREET CORE 
Thin units $(<0.05 \mathrm{ft})$ are described where top and bottom of unit are shown as the same depth.

\begin{tabular}{|lc}
\multicolumn{2}{c}{ Depths (ft) } \\
Top & Bottom \\
0.0 & 19.0 \\
& \\
19.0 & 25.5 \\
& \\
25.5 & 27.0 \\
& \\
33.0 & 37.1 \\
37.1 & 37.8 \\
& \\
& \\
37.8 & 39.1 \\
& \\
40.4 & 41.6 \\
& \\
43.2 & 43.7 \\
& \\
43.7 & 45.9 \\
45.9 & 46.3 \\
& \\
46.3 & 47.4 \\
47.4 & 47.9 \\
47.9 & 49.0 \\
49.0 & 50.3 \\
50.3 & 50.7 \\
50.7 & 51.7 \\
57.4 & 59.6 \\
&
\end{tabular}

$59.6 \quad 80.3$

$\begin{array}{ll}80.3 & 81.5\end{array}$

$86.5 \quad 87.6$

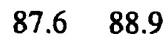

88.990 .8

$91.5 \quad 92.5$

$92.5 \quad 95.2$

95.296 .6

$96.6 \quad 96.8$

$96.8 \quad 97.7$

$97.7 \quad 99.0$

$\begin{array}{ll}99.0 & 99.1\end{array}$

$99.1 \quad 99.2$

$99.2 \quad 99.3$

$99.3 \quad 99.4$

$99.4 \quad 99.4$

$\begin{array}{ll}99.4 & 99.8\end{array}$

$99.8 \quad 99.9$

$99.9 \quad 100.6$

$100.6 \quad 100.7$

$100.7 \quad 101.6$

$101.6 \quad 101.7$

$101.7 \quad 102.2$

$102.2 \quad 102.3$

\section{Description}

Pale brown to yellowish brown (10YR6/3-5/4) and strong brown (7.5 YR5/6) fine sand, some medium sand, with scattered coarse sand and granular to pebbly sand intervals, loose, weak reaction to $\mathrm{HCl}$ Light yellowish brown to dark yellowish brown (10YR6-4/4) medium sand, moderately sorted, loose, no reaction to $\mathrm{HCl}$

Light yellowish brown to dark yellowish brown (10YR6-4/4) medium sand, moderately sorted, loose, no reaction to $\mathrm{HCl}$

Light yellowish brown to dark yellowish brown (10YR6-4/4) gravelly coarse sand, poorly sorted, loose Framework gravel with light yellowish brown to dark yellowish brown (10YR6-4/4) fine-to-medium, moderately sorted, loose sand matrix, gravel clasts are pebbles and small cobbles, moderately rounded, elongate to subequant, composed of granite, quartzite, basalt, sandstone

Light yellowish brown (10YR6/4) gravelly coarse sand, poorly sorted, loose, containing granules and scattered, elongate, moderately rounded pebbles

Light yellowish brown to dark yellowish brown (10YR6-4/4) gravelly coarse sand, poorly sorted, loose, containing granules and scattered, elongate, moderately rounded pebbles

Framework gravel with light yellowish brown to dark yellowish brown (10YR6-4/4) fine-to-medium, moderately sorted, loose sand matrix

Light yellowish brown (10YR6/4) coarse sand, poorly sorted, loose, no reaction to $\mathrm{HCl}$

Framework gravel with light yellowish brown to dark yellowish brown (10YR6-4/4) fine-to-medium, moderately sorted, loose sand matrix

Light yellowish brown (10YR6/4) coarse sand, poorly sorted, loose, no reaction to $\mathrm{HCl}$

Yellowish brown to brown (10-7.5YR5/4) medium to coarse sand, moderately sorted, loose, massive Light yellowish brown to dark yellowish brown (10YR6-4/4) gravelly coarse sand, poorly sorted, loose Yellowish brown to brown (10-7.5YR5/4) medium to coarse sand, moderately sorted, loose, massive Light yellowish brown to dark yellowish brown (10YR6-4/4) gravelly coarse sand, poorly sorted, loose Light yellowish brown (10YR6/4) coarse sand, poorly sorted, loose, no reaction to $\mathrm{HCl}$

Framework gravel with light yellowish brown to dark yellowish brown (10YR6-4/4) fine-to-medium, moderately sorted, loose sand matrix, gravel clasts are pebbles and small cobbles, moderately rounded, elongate to subequant, composed of granite, quartzite, basalt, sandstone

Framework gravel with light yellowish brown to dark yellowish brown (10YR6-4/4) fine-to-medium, moderately sorted, loose sand matrix, gravel clasts are pebbles and small cobbles, moderately rounded, elongate to subequant, composed of granite, quartzite, basalt, sandstone

Yellowish brown to brown (10-7.5YR5/4) medium sand, moderately sorted, loose, massive

Light yellowish brown (10YR6/4) coarse sand, poorly sorted, loose, no reaction to $\mathrm{HCl}$

Yellowish brown to brown (10-7.5YR5/4) medium to coarse sand, moderately sorted, loose, massive

Light yellowish brown to dark yellowish brown (10YR6-4/4) gravelly coarse sand, poorly sorted, loose

Light yellowish brown (10YR6/4) coarse sand, poorly sorted, loose, no reaction to $\mathrm{HCl}$

Yellowish brown to brown (10-7.5YR5/4) medium sand, moderately sorted, loose, massive

Yellowish brown to brown (10-7.5YR5/4) medium sand, moderately sorted, loose, massive

Red (2.5YR4/6) silty clay, indistinctly laminated, low dry strength, nonplastic

Yellowish brown to brown (10-7.5YR5/4) medium sand, moderately sorted, loose, massive

Yellowish brown to brown (10-7.5YR5/4) fine sand, moderately sorted, loose

Reddish brown (5YR5/4) silt and silty clay, indistinctly laminated, low dry strength, nonplastic

Brown (7.5YR5/4) silty fine sand, poorly sorted, loose, massive

Reddish brown (5YR5/4) silty clay, indistinctly laminated, low dry strength, nonplastic

Brown (7.5YR5/4) silty fine sand, poorly sorted, loose, massive

Reddish brown (5YR5/4) silt and silty clay, indistinctly laminated, low dry strength, nonplastic

Brown (7.5YR5/4) silty fine sand, poorly sorted, loose, massive

Reddish brown (5YR5/4) silt and silty clay, indistinctly laminated, low dry strength, nonplastic Brown (7.5YR5/4) silty fine sand, poorly sorted

Reddish brown (5YR5/4) silt and silty clay, indistinctly laminated, low dry strength, nonplastic

Brown (7.5YR5/4) silty fine sand, poorly sorted, loose, massive

Reddish brown (5YR5/4) silt and silty clay, indistinctly laminated, low dry strength, nonplastic Brown (7.5YR5/4) silty fine sand, poorly sorted, loose, massive

Reddish brown (5YR5/4) silt and silty clay, indistinctly laminated, low dry strength, nonplastic 
$102.3 \quad 102.8$

$102.8 \quad 102.8$

$102.8 \quad 102.9$

$102.9 \quad 103.0$

$103.0 \quad 103.4$

$103.4 \quad 103.6$

$103.6 \quad 104.1$

$104.1 \quad 104.1$

$104.1 \quad 104.2$

$104.2 \quad 104.4$

$104.4 \quad 104.7$

$104.7 \quad 105.6$

$105.6 \quad 105.9$

$105.9 \quad 106.0$

$106.0 \quad 106.3$

106.3107 .1

$107.1 \quad 107.3$

$107.3 \quad 107.8$

107.8108 .1

$108.1 \quad 108.4$

$108.4 \quad 109.8$

$110.0 \quad 110.9$

$110.9 \quad 111.3$

$111.3 \quad 111.6$

$111.6 \quad 114.6$

$114.6 \quad 114.8$

$114.8 \quad 118.7$

$120.0 \quad 120.4$

$120.4 \quad 120.8$

$120.8 \quad 122.6$

$122.8 \quad 124.4$

$124.4 \quad 126.4$

$133.0 \quad 135.5$

$135.5 \quad 135.9$

$135.9 \quad 138.5$

$140.5 \quad 144.7$

$145.9 \quad 146.0$

$146.0 \quad 147.0$

$147.0 \quad 147.3$

$147.3 \quad 148.8$

$148.9 \quad 149.4$

$149.4 \quad 149.5$

$149.5 \quad 150.9$

$150.9 \quad 151.2$

$151.2 \quad 151.3$

$151.3 \quad 152.0$

$158.9 \quad 159.5$

159.5160 .1

$160.1 \quad 163.4$

$163.4 \quad 164.1$

$164.1 \quad 164.4$

$164.6 \quad 164.9$

$164.9 \quad 165.0$

165.0166 .1

$166.1 \quad 166.2$

$166.2 \quad 167.5$

167.5168 .3

168.3169 .1
Brown (7.5YR5/4) silty fine sand, poorly sorted, loose, massive

Reddish brown (5YR5/4) silt and silty clay, indistinctly laminated, low dry strength, nonplastic Brown (7.5YR5/4) silty fine sand, poorly sorted, loose, massive

Reddish brown (5YR5/4) silt and silty clay, indistinctly laminated, low dry strength, nonplastic Brown (7.5YR5/4) silty fine sand, poorly sorted, loose, massive

Reddish brown (5YR5/4) silt and silty clay, indistinctly laminated, low dry strength, nonplastic Brown (7.5YR5/4) silty fine sand, poorly sorted, loose, massive

Reddish brown (5YR5/4) silt and silty clay, indistinctly laminated, low dry strength, nonplastic Brown (7.5YR5/4) silty fine sand, poorly sorted, loose, massive

Reddish brown (5YR5/4) silt and silty clay, indistinctly laminated, low dry strength, nonplastic Brown (7.5YR5/4) silty fine sand, poorly sorted, loose, massive

Brown (7.5YR5/4) silty fine sand, poorly sorted, loose, massive

Yellowish brown to brown (10-7.5YR5/4) medium sand, moderately sorted, loose, massive Reddish brown (5YR5/4) silty clay, indistinctly laminated, low dry strength, nonplastic Yellowish brown to brown (10-7.5YR5/4) medium sand, moderately sorted, loose, massive Yellowish brown to brown (10-7.5YR5/4) medium sand, moderately sorted, loose, massive Light yellowish brown to dark yellowish brown (10YR6-4/4) gravelly coarse sand, poorly sorted, loose Yellowish brown to brown (10-7.5YR5/4) medium sand, moderately sorted, loose, massive Yellowish brown to brown (10-7.5YR5/4) medium sand, moderately sorted, loose, massive Brown (7.5YR5/4) silty fine sand, poorly sorted, loose, massive

Light yellowish brown (10YR6/4) coarse sand, poorly sorted, loose, no reaction to $\mathrm{HCl}$ Light yellowish brown (10YR6/4) coarse sand, poorly sorted, loose

Yellowish brown to brown (10-7.5YR5/4) medium sand, moderately sorted, loose, massive Reddish brown (5YR5/4) silty clay, indistinctly laminated, low dry strength, nonplastic Light yellowish brown (10YR6/4) coarse sand, poorly sorted, loose, no reaction to $\mathrm{HCl}$ Reddish brown (5YR5/4) silty clay, indistinctly laminated, low dry strength, nonplastic Yellowish brown to brown (10-7.5YR5/4) medium sand, moderately sorted, loose, massive Yellowish brown to brown (10-7.5YR5/4) medium sand, moderately sorted, loose, massive Reddish brown (5YR5/4) silty clay, indistinctly laminated, low dry strength, nonplastic Light yellowish brown (10YR6/4) coarse sand, poorly sorted, loose, no reaction to $\mathrm{HCl}$ Yellowish brown to brown (10-7.5YR5/4) medium sand, moderately sorted, loose, massive Red (2.5YR4/6)clay, indistinctly laminated, low dry strength, nonplastic

Light yellowish brown (10YR6/4) coarse sand, poorly sorted, loose, no reaction to $\mathrm{HCl}$ Reddish brown (5YR5/4) silty clay, indistinctly laminated, low dry strength, nonplastic Light yellowish brown (10YR6/4) coarse sand, poorly sorted, loose

Yellowish brown to brown (10-7.5YR5/4) medium sand, moderately sorted, loose, massive Yellowish brown to brown (10-7.5YR5/4) medium sand, moderately sorted, loose, massive Yellowish brown to brown (10-7.5YR5/4) medium sand, moderately sorted, loose, massive Reddish brown (5YR5/4) silt and silty clay, indistinctly laminated, low dry strength, nonplastic Brown (7.5YR5/4) silty fine sand, poorly sorted, loose, massive

Reddish brown (5YR5/4) silty clay, indistinctly laminated, low dry strength, nonplastic Brown (7.5YR5/4) silty fine sand, poorly sorted, loose, massive

Reddish brown (5YR5/4) clayey silty fine sand, indistinctly laminated, low dry strength, nonplastic

Reddish brown (5YR5/4) clayey silty fine sand, poorly sorted, loose, massive

Reddish brown (5YR5/4) silty clay, indistinctly laminated, low dry strength, nonplastic

Reddish brown (5YR5/4) clayey silty very fine sand, indistinctly laminated, low dry strength, nonplastic Light yellowish brown to dark yellowish brown (10YR6-4/4) gravelly coarse sand, poorly sorted, loose, massive

Light yellowish brown (10YR6/4) coarse sand, poorly sorted, loose, massive, no reaction to $\mathrm{HCl}$

Light yellowish brown to dark yellowish brown (10YR6-4/4) gravelly coarse sand, poorly sorted, loose, massive

Framework pebble gravel

Brown (7.5YR5/4) silty fine sand, poorly sorted with abundant carbonate blebs

Light yellowish brown (10YR6/4) coarse sand, poorly sorted, loose, no reaction to $\mathrm{HCl}$

Red (2.5YR4/6) silty clay, indistinctly laminated, low dry strength, nonplastic

Brown (7.5YR5/4) silty fine sand, poorly sorted, thinly bedded, loose

Red (2.5YR4/6) silty clay, indistinctly laminated, low dry strength, nonplastic

Brown (7.5YR5/4) silty fine sand, poorly sorted, loose, massive

Reddish brown (5YR5/4) clayey silty fine sand, indistinctly laminated, low dry strength, nonplastic Brown (7.5YR5/4) silty fine sand, poorly sorted, loose, massive 
$\begin{array}{ll}169.1 & 170.0\end{array}$

$\begin{array}{lll}170.6 & 172.7\end{array}$

$\begin{array}{lll}172.7 & 173.1\end{array}$

$173.1 \quad 174.0$

$\begin{array}{ll}174.0 & 174.9\end{array}$

$\begin{array}{lll}175.6 & 175.7\end{array}$

$\begin{array}{lll}175.7 & 176.5\end{array}$

$176.5 \quad 176.6$

$\begin{array}{ll}176.6 & 177.9\end{array}$

$\begin{array}{lll}177.9 & 178.7\end{array}$

$178.8 \quad 178.9$

$178.9 \quad 179.0$

$179.0 \quad 179.1$

$\begin{array}{lll}179.1 & 179.3\end{array}$

$179.3 \quad 179.5$

$179.5 \quad 179.8$

$179.8 \quad 180.1$

$\begin{array}{lll}180.1 & 180.3\end{array}$

$180.3 \quad 181.1$

$181.1 \quad 182.6$

$188.8 \quad 189.2$

$190.5 \quad 190.8$

$190.8 \quad 192.6$

$192.6 \quad 194.2$

$200.5 \quad 201.7$

$201.7 \quad 202.5$

$202.5 \quad 202.9$

$202.9 \quad 203.0$

$203.0 \quad 204.5$

$204.5 \quad 210.9$

$211.1 \quad 211.7$

$\begin{array}{ll}212.0 & 212.4\end{array}$

$221.1 \quad 221.3$

$\begin{array}{ll}221.3 & 222.0\end{array}$

$222.0 \quad 223.4$

$223.4 \quad 224.1$

$\begin{array}{ll}231.1 & 231.2\end{array}$

$236.1 \quad 237.2$

$237.2 \quad 239.2$

$239.2 \quad 239.5$

$243.0 \quad 243.1$

$243.1 \quad 243.3$

$243.3 \quad 243.4$

$243.4 \quad 243.9$

$243.9 \quad 244.0$

$244.0 \quad 244.3$

$244.3 \quad 245.7$

$\begin{array}{ll}245.7 & 246.1\end{array}$

$248.8 \quad 249.0$

$249.0 \quad 249.3$

$249.3 \quad 249.9$
Pale brown (10YR6/3) medium to coarse sand, poorly sorted, loose, no reaction to $\mathrm{HCl}$

Pale brown (10YR 6/3) coarse sand, moderately sorted, loose, massive

Yellowish brown (10YR5/4) silty fine sand, poorly sorted, loose, massive

Brown (7.5YR 5/4) silty medium sand, faint fine grained laminae

Brown (7.5YR5/4) coarse sand, moderately sorted, loose

Reddish brown (5YR5/4) silty clay, indistinctly laminated, low dry strength, nonplastic

Brown (7.5YR5/4) coarse sand, moderately sorted, loose

Reddish brown (5YR5/4) silty fine sand, poorly sorted, loose, massive

Brown (7.5YR5/4) coarse sand, moderately sorted, loose

Brown (7.5YR5/4) coarse sand, moderately sorted, loose, with reddish brown (5YR5/4) clay ripup

intraclasts

Reddish brown (5YR4/4) coarse sand, moderately sorted, loose, massive

Brown (7.5YR5/4) fine sandstone, carbonate cemented, strong reaction to $\mathrm{HCl}$

Red (2.5YR4/6) silty clay, indistinctly laminated, low dry strength, nonplastic

Red (2.5YR4/6) silty clay with red clay laminations

Reddish brown (5YR5/4) clay, massive, medium dry strength, low plasticity

Brown (7.5YR5/4) clayey silty fine sand, poorly sorted

Reddish brown (5YR5/4) clay, massive, moderate dry strength, low plasticity

Reddish brown (5YR5/4) clayey silty fine sand, poorly sorted

Reddish brown (5YR4/4) silty clay and clay, indistinctly laminated, low dry strength, nonplastic

Reddish brown (5YR5/4) silty fine sand, poorly sorted, loose, massive

Brown to dark brown (7.5YR4/4) silty fine sand, poorly sorted, loose, massive; light brown (7.5YR6/4)

thin basal carbonate cemented sandstone, moderately cemented

Pink (7.5YR7/4) coarse sand, laminated, weak carbonate cement, moderately cemented

Brown (7.5YR5/4) coarse sand, moderately sorted, loose, laminated

Brown (7.5YR5/4) coarse sand, moderately sorted, loose, massive

Brown to dark brown (7.5YR4/4) medium sand, massive

Strong brown (7.5YR4/6) coarse sand, moderately sorted, loose, massive, reddish brown (5YR5/4) clay

ripup intraclasts

Strong brown (7.5YR4/6) coarse sand, moderately sorted, loose, massive

White (7.5YR8/0) sandstone, carbonate cemented, strongly cemented, strong reaction to $\mathrm{HCl}$, thin

basal mudstone

Brown (7.5YR5/4) coarse sand, moderately sorted, loose, indistinctly laminated

Reddish brown (5YR4/4) clay and silty clay, massive, medium dry strength, low plasticity, silty clay has interbeds and interlaminae of silt and fine sand

Light brown (7.5YR6/4) coarse sand, carbonate cemented, weakly cemented at 211.7, and 212.0 depths; reddish yellow (7.5YR6/6) coarse sand, weakly cemented

Brown (7.5YR5/4) silty clay, interlaminated silty sand, indistinctly laminated, low dry strength, nonplastic

Brown (7.5YR5/4) medium sand, reddish brown (5YR5/4) clay laminae, white carbonate blebs, carbonate cement sandstone pieces, moderately cemented, strong reaction to $\mathrm{HCl}$

Brown (7.5YR5/4) medium sand

Brown (7.5YR5/4) coarse sand, moderately sorted, loose, massive

Reddish brown (5YR5/4) medium sand, ranging from fine to coarse sand, interlaminated with light brown (7.5YR6/4) silty fine sand, poorly sorted

Reddish brown (5YR5/4) coarse sand, moderately sorted, weakly cemented

Brown (7.5YR5/4) silty medium sand, fining upward, pinkish carbonate zone

Reddish brown (5YR5/4) clay and silty clay, fining upward sequence with a carbonate cemented zone at top, strongly cemented, strong reaction to $\mathrm{HCl}$

Yellowish red (5YR5/6) silty clay and brown (7.5YR5/4) silty sand, interlaminated, traces of coarse sand

Yellowish red (5YR5/6) silty clay, indistinctly laminated, low dry strength, nonplastic

Brown (7.5YR5/4) sandy silt, laminated

Brown (7.5YR5/4) fine sand, moderately sorted, loose, massive

Brown (7.5YR5/4) coarse sand, moderately sorted, loose

Brown (7.5YR5/4) silty clay, indistinctly laminated, low dry strength, nonplastic

Reddish brown (5YR5/4) clayey silty fine sand, poorly sorted, loose, massive

Strong brown (7.5YR5/6) medium sand and brown to dark brown (7.5YR4/4) silty sand, interlaminated

Strong brown (7.5YR5/6) medium sand

Brown (7.5YR5/4) medium sand, ranging from fine to coarse, massive

Reddish brown (5YR5/4) silty fine sand, poorly sorted

Reddish brown (5YR5/4) silty clay, traces of fine sand, indistinctly laminated, low dry strength, nonplastic 
$249.9250 .0 \quad$ Reddish brown (5YR5/4) silty clay, , indistinctly laminated, low dry strength, nonplastic, white carbonate nodules

250.0250 .1

$250.1 \quad 250.2$

$250.2 \quad 251.6$

$251.6 \quad 252.0$

$252.0 \quad 255.2$

$259.8 \quad 260.4$

$260.4 \quad 260.8$

$260.8 \quad 260.9$

$260.9 \quad 261.1$

261.1261 .5

$261.5 \quad 261.8$

$261.8 \quad 262.6$

$262.6 \quad 264.0$

$264.0 \quad 264.8$

$264.8 \quad 265.7$

$265.7 \quad 268.3$

$268.7 \quad 268.9$

269.9270 .1

\begin{tabular}{ll}
$270.1 \quad 270.2$ \\
\hline
\end{tabular}

$270.2 \quad 270.8$

$270.8 \quad 271.0$

$271.0 \quad 271.9$

$271.9 \quad 272.7$

$\begin{array}{ll}273.1 & 274.8\end{array}$

$274.8 \quad 277.2$

$277.2 \quad 277.7$

$278.1 \quad 278.2$

$278.2 \quad 278.5$

$\begin{array}{ll}278.5 & 278.7\end{array}$

$278.7 \quad 279.2$

$\begin{array}{lll}279.2 & 279.7\end{array}$

$279.7 \quad 279.9$

$279.9 \quad 281.4$

$281.4 \quad 281.6$

$281.6 \quad 281.9$

$282.5 \quad 287.9$

$290.9 \quad 291.0$

$291.0 \quad 291.4$

$291.4 \quad 291.7$

$291.7 \quad 293.8$

$293.8 \quad 294.5$

$294.5 \quad 294.7$

$294.7 \quad 295.1$

$295.1 \quad 295.2$

$295.2 \quad 296.3$

$296.3 \quad 296.5$

$301.9 \quad 302.4$

$302.4 \quad 302.7$

$302.7 \quad 303.0$

$303.0 \quad 304.4$

$304.4 \quad 305.4$
Reddish brown (5YR5/4) silty fine sand, poorly sorted, loose, massive

Reddish brown (5YR5/4) silty clay, , indistinctly laminated, low dry strength, nonplastic, carbonate nodules Reddish brown (5YR5/4) to (2.5YR5/4) silty clay and clay, indistinctly laminated, low dry strength, nonplastic, with manganese oxide dendrites

Brown (7.5YR5/4) silty fine sand, poorly sorted, weakly carbonate cemented, thin silty clay interbeds Reddish brown (5YR5/4) to (2.5YR5/4) silty clay and clay, faint banding, carbonate nodules

Brown (7.5YR5/4) clay, indistinctly laminated, low dry strength, nonplastic

Strong brown (7.5YR5/6) silty fine sand, poorly sorted, loose, massive, grain size ranging from fine to medium sand, fining-upward unit, moderately cemented layers

Brown (7.5YR5/4) clayey silt and clay, interlaminated, indistinctly laminated, low dry strength, nonplastic

Reddish brown (5YR5/4) clay, indistinctly laminated, low dry strength, nonplastic

Reddish brown (5YR5/4) medium sand, ranging from fine to medium sand, red (5YR) clay interbeds

Light brown (7.5YR6/4) sandy silty clay, indistinctly laminated, low dry strength, nonplastic, red (5YR) clay laminations

Brown (7.5YR5/4) silty clay, , indistinctly laminated, low dry strength, nonplastic interbeds of fine sand Brown (7.5YR5/4) clay, disturbed, medium sand breccia

Brown (7.5YR5/4) coarse sand, ranging from fine to coarse sand, moderately sorted, loose

Brown (7.5YR5/4) coarse sand, ranging from fine to coarse sand, moderately sorted, loose, massive

Reddish brown (5YR5/4) silty fine sand, poorly sorted, loose, massive

Light reddish brown (5YR6/4) silty fine sand, poorly sorted, loose, massive

Pinkish white (5YR8/2) medium sand, weakly cemented

Light brown (7.5YR6/4) clayey silty fine sand, poorly sorted, loose, massive

Reddish brown (5YR5/4) clay

Light reddish brown (5YR6/4) sandy clay and pinkish white (5YR8/2) silty sand, basal calcite cemented, moderately cemented

Brown (7.5YR5/4) medium sand with reddish brown (5YR5/4) clay ripups

Light brown (7.5YR6/4) silty medium sand, moderately sorted, loose, massive

Light brown (7.5YR6/4) silty fine sand, poorly sorted, loose, massive

Strong brown (7.5YR5/6) medium sand

Light brown (7.5YR6/4) clayey silty fine sand, poorly sorted, loose, massive

Strong brown (7.5YR5/6) clayey silty fine sand, poorly sorted, loose, massive

Strong brown (7.5YR5/6) silty clay with brown to dark brown (7.5YR4/2) silt stringers

Strong brown (7.5YR4/6) clay

Red (2.5YR4/6) clay with brown to dark brown (7.5YR4/2) silt laminations

Yellowish red (5YR5/6) sandy clay

Reddish brown (2.5YR5/4) clayey silty fine sand, poorly sorted, loose, massive

Brown (7.5YR5/4) silty fine sand, poorly sorted, loose, massive

Reddish brown (2.5YR5/4) clayey silty fine sand, poorly sorted, loose, massive

Yellowish red (5YR5/6) silty clay and brown (7.5YR5/4) silty fine sand, poorly sorted, loose, massive, interlaminated

Brown (7.5YR5/4) silty fine sand, poorly sorted, loose, massive

Light yellowish brown (10YR6/4) medium sand, moderately sorted

Light yellowish brown (10YR6/4) clayey sandy silt

Brown (7.5YR5/4) silty clay

Yellowish brown (10YR5/6) medium sand, 1.5-1.0 phi mode, ranging from fine to medium sand

Yellowish brown (10YR5/6) medium sand, 1.5-1.0 phi mode, ranging from fine to coarse sand

Pink (7.5YR7/4) coarse sand, moderately sorted, loose, weakly calcite cemented

Yellowish brown (10YR5/6) medium sand, 1.5-1.0 phi mode, ranging from fine to coarse sand, moderately sorted, loose

Pink (7.5YR7/4) coarse sand, moderately sorted, weakly calcite cemented

Strong brown (7.5YR5/6) medium sand, 2.0-1.5 phi mode, ranging from fine to coarse sand

Pink (7.5YR7/4) coarse sand, moderately sorted, loose, weakly calcite cemented

Strong brown (7.5YR5/6) silty fine sand, poorly sorted, massive, moderately cemented

Strong brown (7.5YR5/6) silty fine sand, poorly sorted, massive

Strong brown (7.5YR5/6) coarse sand, 1.0-0.5 phi mode, grading to medium sand 2.0-1.5 phi mode,

ranging from fine to coarse sand, poorly sorted

Strong brown (7.5YR5/6) medium sand, $1.5-1.0$ phi mode, moderately sorted

Reddish brown (5YR5/4) to yellowish red (5YR5/6) silty clay and clay, interlaminated 
Strong brown (7.5YR5/6-4/6) clayey silty fine sand, poorly sorted, massive, 3.0-2.5 phi mode, weakly cemented

306.4307 .1 Strong brown (7.5YR5/6-4/6) clayey silty fine sand, poorly sorted, massive, 3.0-2.5 phi mode, weakly cemented

$307.1 \quad 307.2$

$307.2 \quad 307.5$

$307.5 \quad 308.0$

Reddish yellow (7.5YR6/6) fine sand, weakly carbonate cemented, carbonate nodules, mottled

Reddish brown (5YR5/4) clay, massive, low dry strength, low plasticity, basal silty clay

Reddish brown (5YR5/4) silty clayey fine sand, basal reddish yellow to yellowish red (5YR6/6-5/6)

medium sand, 2.5-1.5 phi mode, ranging from fine to medium sand, poorly sorted, massive

$\begin{array}{ll}311.9 & 312.1\end{array}$

$312.1 \quad 312.4$

$312.4 \quad 313.1$

313.1313 .9

$313.9 \quad 314.1$

$\begin{array}{ll}314.1 & 314.3\end{array}$

$314.3 \quad 314.4$

$321.5 \quad 323.8$

$323.8 \quad 324.5$

$\begin{array}{ll}324.5 & 324.7\end{array}$

$324.7 \quad 325.2$

$325.2 \quad 325.4$

$325.4 \quad 325.9$

$325.9 \quad 326.5$

$326.5 \quad 326.9$

326.9327 .1

$327.1 \quad 327.4$

$327.4 \quad 327.5$

$327.5 \quad 327.9$

$327.9 \quad 328.4$

$328.4 \quad 328.5$

$328.5 \quad 328.6$

$\begin{array}{lll}328.6 & 328.7\end{array}$

$\begin{array}{lll}332.0 & 332.5\end{array}$

$332.5 \quad 332.6$

$332.6 \quad 333.5$

$333.5 \quad 335.0$

$\begin{array}{lll}335.0 & 335.9\end{array}$

$335.9 \quad 336.0$

$\begin{array}{lll}336.0 & 336.3\end{array}$

$336.3 \quad 336.6$

$\begin{array}{lll}337.0 & 337.1\end{array}$

$337.1 \quad 338.5$

$342.0 \quad 342.3$

$342.3 \quad 342.5$

$342.5 \quad 342.5$

$342.5 \quad 342.6$

$346.9 \quad 347.7$

$\begin{array}{lll}347.7 & 351.8\end{array}$

$351.8 \quad 352.0$

$352.0 \quad 352.1$

Reddish brown to strong brown (7.5YR6/6-5/6) silty fine to medium sand, $2.0-1.5$ phi mode

Strong brown (7.5YR5/6) silty sandy clay

Reddish brown to strong brown (7.5YR6/6-5/6) silty fine sand, poorly sorted, massive weakly cemented

Strong brown (7.5YR5/6) silty clay, indistinctly laminated, low dry strength, nonplastic

Strong brown (7.5YR5/6) silty clay, indistinctly laminated, low dry strength, nonplastic, carbonate nodules

Strong brown (7.5YR5/6) silty clay, indistinctly laminated, low dry strength, nonplastic

Strong brown (7.5YR4/6) clay, indistinctly laminated, low dry strength, nonplastic

Strong brown (7.5YR5/6) to yellowish red (5YR5/6) silty medium sand, 2.0-1.5 phi mode, ranging from

fine to medium sand, fining up unit, basal reddish brown (5YR5/4) clay ripup intraclasts

Dark brown to brown (7.5YR4/4) silty clay and pink (7.5YR7/4) silty fine sand, poorly sorted,

interlaminated, carbonate rich

Reddish brown (5YR4/4) clay, low dry strength, low plasticity, laminated

Dark brown to brown (7.5YR4/4) silty clay and pink (7.5YR7/4) silty fine sand, poorly sorted,

interlaminated, carbonate rich

Brown (7.5YR5/4) silty fine sand, poorly sorted, loose, massive

Reddish brown (5YR4/4) clay, low dry strength, low plasticity, laminated

Brown (7.5YR5/4) silty very fine sand, 3.0-2.5 phi mode, poorly sorted, loose, massive

Light brown (7.5YR6/4) silty fine sand, poorly sorted, massive

Strong brown (7.5YR5/6) silty fine sand, poorly sorted, massive

Strong brown (7.5YR5/6) silty medium sand, ranging from fine to coarse sand

Reddish brown (5YR5/4) and yellowish brown (10YR5/4) clay, massive, low dry strength, nonplastic

Dark brown to brown (7.5YR4/4) silty clay and pink (7.5YR7/4) silty fine sand, poorly sorted, carbonate rich

Light brown (7.5YR6/4) to brown (7.5YR5/4) silty fine sand, poorly sorted, 2-6 millimeter laminations of reddish brown (5YR5/4) clay

Yellowish brown (10YR5/4) clay, low dry strength, nonplastic, massive

Reddish brown (5YR5/4) silty clay, massive, low dry strength, nonplastic, laminated

Brown (7.5YR5/4) silty medium sand, sand ranging from fine to coarse

Brown (7.5YR5/4) silty fine sand, poorly sorted, loose, massive

Pinkish gray (7.5YR7/2) silty very fine sand, poorly sorted, massive weakly carbonate cemented

Yellowish red (5YR4/6) silty clay and clay, basal sand

Strong brown (7.5YR5/6) medium sand, 2.0-1.5 phi mode, ranging from fine to medium sand

Strong brown (7.5YR5/6) medium sand, ranging from fine to coarse sand

Strong brown (7.5YR5/6) silty fine sand, poorly sorted, massive, sand ranging from fine to medium

Yellowish red (5YR4/6) clay, low dry strength, nonplastic, massive

Strong brown (7.5YR5/6) fine sand, 2.5-2.0 phi mode, ranging from fine to medium sand

Yellowish red (5YR5/6) silty clay

Strong brown (7.5YR5/6) medium sand, 3.0-1.5 phi mode, ranging from fine to medium sand

Strong brown (7.5YR5/6) silty medium sand, 3.0-1.0 phi mode, ranging from fine to medium sand

Yellowish red (5YR5/6) fine sandy clay

Yellowish red (5YR5/6) silty clay, strongly cemented upper boundary

Very pale brown (10YR7/4) to light yellowish brown (10YR6/4) fine silty sand, poorly sorted, massive

Strong brown (7.5YR5/6) medium sand, 3.0-1.5 phi mode, ranging from fine to medium sand

Strong brown (7.5YR5/6) silty fine sand, poorly sorted, massive, $3.0-2.0$ phi mode, ranging from fine to medium sand, discontinuously and moderately cemented zones of silty, clayey fine sand

Strong brown (7.5YR5/6) silty fine sandstone, 3.0-2.0 phi mode, ranging from fine to medium sand, poorly sorted, massive strongly cemented, strong reaction to $\mathrm{HCl}$

$352.1 \quad 353.3$

$353.3 \quad 353.6$

Strong brown (7.5YR5/6) fine sand, 3.0-2.0 phi mode, ranging from fine to medium sand, strongly cemented, strong reaction to $\mathrm{HCl}$

Strong brown (7.5YR5/6) silty fine sand, poorly sorted, 3.0-2.0 phi mode, ranging from fine to coarse sand, poorly sorted, massive

Strong brown (7.5YR5/6) fine sand, 3.0-2.0 phi mode, ranging from very fine to fine sand, moderately 
$354.0 \quad 354.1$

$354.1 \quad 354.6$

$357.4 \quad 357.5$

$357.5 \quad 357.7$

$357.7 \quad 358.1$

$358.1 \quad 359.2$

$359.2 \quad 359.3$

$359.3 \quad 359.4$

$359.4 \quad 359.5$

$359.5 \quad 359.9$

$359.9 \quad 361.3$

$361.3 \quad 361.6$

$361.6 \quad 361.8$

$\begin{array}{ll}361.8 & 362.4\end{array}$

$362,4 \quad 363.3$

$369.3 \quad 369.4$

$369.4 \quad 373.9$

$374.3 \quad 376.8$

$378.7 \quad 379.4$

$379.4 \quad 381.1$

$383.4 \quad 383.5$

$383.5 \quad 383.6$

$383.6 \quad 383.7$

$394.4 \quad 399.6$

$399.6 \quad 399.9$

$399.9 \quad 400.1$

$401.0 \quad 403.1$

$403.1 \quad 404.1$

$404.1 \quad 404.2$

$404.2 \quad 404.3$

$404.3 \quad 404.5$

$404.5 \quad 404.7$

$404.7 \quad 405.3$

$405.3 \quad 405.4$

$405.4 \quad 405.5$

$405.5 \quad 406.4$

$406.4 \quad 407.8$

$407.8 \quad 408.5$

$408.5 \quad 409.0$

$409.0 \quad 409.3$

$410.5 \quad 410.9$

$410.9 \quad 411.6$

$411.6 \quad 411.8$

$411.8 \quad 412.0$

$412.0 \quad 412.3$

$416.4 \quad 419.8$ sorted

Brown (7.5YR5/4) silty clayey fine sand, poorly sorted, loose, massive

Brown (7.5YR5/4) silty medium sand, $2.5-1.5$ phi mode, ranging from fine to medium sand

Brown (7.5YR5/4) silty medium sand, 2.5-1.5 phi, ranging from fine to medium sand, discontinuous weakly cemented zone

Strong brown (7.5YR5/6) silty medium sand, 2.5-1.5 phi mode, ranging from fine to medium sand

Reddish yellow (7.5YR6/8) clayey silty fine sand, poorly sorted, massive

Reddish yellow (7.5YR6/8) silty very fine sand, poorly sorted, loose, faintly cross-laminated

Yellowish red (5YR5/5) clay, low dry strength, nonplastic, silty laminations

Strong brown (7.5YR5/6) silt and very fine sand, interlaminated, poorly sorted, loose, massive

Yellowish red (5YR5/5) clay, low dry strength, nonplastic, silty laminations

Light brown (7.5YR6/4) silty very fine sand, ranging from fine to medium sand, poorly sorted, indistinctly laminated

Brown (7.5YR5/4) silty fine sand, poorly sorted, ranging from fine to medium sand, red (5YR) clay

laminae 2 millimeters thick

Strong brown (7.5YR5/6) clayey silty fine sand, poorly sorted, laminated

Strong brown (7.5YR5/6) medium sand, 2.0-1.5 phi mode, ranging from fine to coarse sand, indistinctly laminated, moderately sorted

Strong brown (7.5YR5/6) silty fine sand, poorly sorted, distinctly laminated, red (5YR) clay laminae

Strong brown (7.5YR5/8) medium sand, 2.0-1.5 phi mode, ranging from fine to coarse sand, distinctly

laminated, clean, poorly sorted, some silty laminae

Reddish brown (5YR4/3) sandy silty clay, massive, low dry strength, nonplastic

Strong brown (7.5YR5/6) medium sand, 2.5-1.5 phi mode, laminated to indistinctly laminated

Strong brown (7.5YR5/6) silty fine sand, poorly sorted, loose, massive

Strong brown (7.5YR5/6) medium sand, moderately sorted

Strong brown (7.5YR5/6) clayey silty medium sand, 3.0-2.0 phi mode, ranging from fine to medium sand

Yellowish red (5YR4/6) silty clay, low dry strength, nonplastic, ripup intraclasts of red clay

Yellowish red (5YR4/6) medium sand, ranging from fine to coarse sand, poorly sorted

Yellowish red (5YR4/6) "Hershey" clay

Brown (7.5YR5/4) fine sand, 2.5-2.0 phi mode, laminated, well sorted

Dark brown to brown (7.5YR4/4) medium sand, 2.0-1.5 phi mode, indistinctly laminated, moderately sorted

Dark brown to brown (7.5YR4/4) coarse sand, 1.0-0.5 phi mode, indistinctly laminated, fining up unit, well sorted

Brown (7.5YR5/4) medium sand, 2.5-1.5 phi, ranging from fine to medium sand, interlaminated, dark mineral laminae, basal crossbedding

Yellowish red (5YR5/6) silty clayey sand and strong brown (7.5YR5/6) very fine sand, 2.5-2.0 phi mode, interlaminated, poorly sorted, loose, massive

Brown (7.5YR5/4) medium sand, 2.0-1.5 phi mode, indistinctly laminated

Brown (7.5YR5/4) fine sand, 3.0-2.5 phi mode, scattered medium sand, 2.5-2.0 phi mode

Light brown (7.5YR6/4) clayey silt and very fine sand, interlaminated, poorly sorted, loose

Brown (7.5YR5/4) silty fine sand, poorly sorted, 3.0-2.5 phi mode, indistinctly laminated

Light brown (7.5YR6/4) fine sand, 2.5-2.0 phi mode, ranging from fine to medium sand, laminated, red

clay microlaminations at top, clay intraclasts

Light yellowish brown (10YR6/4) silty fine sand, poorly sorted, 2.5-2.0 phi mode, ranging from fine sand to medium sand, interlaminated

Pinkish gray (7.5YR6/2) fine sand, 3.0-2.5 phi mode, weakly carbonate cemented

Brown (7.5YR5/4) fine sand, 2.5-2.0 phi mode, ranging from fine to medium sand, indistinct thin clay beds

Light brown (7.5YR6/4) silty fine sand, poorly sorted, 3.0-2.0 phi mode, laminated, carbonate rich

Yellowish red (5YR5/6) silty fine sand, poorly sorted, 3.0-2.5 phi mode, laminated

Reddish brown (5YR5/4) fine sandy silty clay, 4.0-3.5 phi, fining upward to clay

Reddish brown (5YR5/4) clay, indistinctly laminated, low dry strength, nonplastic

Light brown (7.5YR6/4) silty clay, thin beds of silty fine sand, poorly sorted

Light brown (7.5YR6/4) silty fine sand, poorly sorted, crossbedded sand, heavy mineral laminations, reddish brown (5YR5/4) 8-millimeter thick clay laminations

Light brown (7.5YR6/4) silty clay and silty very fine sand, interlaminated, poorly sorted, loose

Brown (7.5YR5/4) silty fine sand, poorly sorted, ranging from fine to medium sand, laminated

Light brown (7.5YR6/4) silty fine sand, poorly sorted, crossbedded sand, heavy mineral laminations,

reddish brown (5YR5/4) 8 millimeter clay laminations

Brown (7.5YR5/4) medium sand, 2.0-1.5 phi mode, ranging from fine to coarse, compact, well sorted, 0.1 
419.8 420.0 Dark yellowish brown (10YR4/4) medium sand, ranging from fine to medium sand, moderately carbonate cemented

$420.0 \quad 420.1$

$427.8 \quad 432.8$

$432.8 \quad 435.1$

$435.1 \quad 435.2$

$435.2 \quad 435.6$

$435.6 \quad 436.4$

$436.4 \quad 436.7$

436.7437 .1

$437.1 \quad 437.2$

$437.2 \quad 437.3$

$437.3 \quad 437.9$

$438.4 \quad 438.6$

$438.6 \quad 438.8$

$438.8 \quad 439.2$

$439.2 \quad 439.8$

$439.8 \quad 439.9$

$439.9 \quad 441.0$

$441.0 \quad 443.2$

$443.4 \quad 443.5$

$443.5 \quad 447.2$

$447.2 \quad 447.3$

$447.3 \quad 447.5$

$447.5 \quad 448.0$

$\begin{array}{lll}456.1 & 457.7\end{array}$

$\begin{array}{lll}457.7 & 459.7\end{array}$

$461.2 \quad 461.5$

$461.5 \quad 461.7$

$461.7 \quad 461.9$

$461.9 \quad 462.2$

$462.2 \quad 462.3$

$462.3 \quad 462.3$

$462.3 \quad 462.9$

$462.9 \quad 464.1$

$464.1 \quad 464.5$

$464.5 \quad 465.6$

$466.1 \quad 466.7$

$466.7 \quad 467.0$

$467.0 \quad 467.6$

$467.6 \quad 468.0$

$468.0 \quad 468.3$

$468.3 \quad 468.4$

$468.4 \quad 469.0$

$469.0 \quad 469.5$

$469.5 \quad 469.8$

$469.8 \quad 470.1$

Dark yellowish brown (10YR4/4) medium sand, ranging from fine to coarse, poorly sorted, loose

Brown (7.5YR5/4) medium sand, 3.0-1.5 phi mode, ranging from fine to medium sands, massive Brown (7.5YR5/4) silty fine sand, poorly sorted, 3.0-2.0 phi mode, ranging from fine to medium sand Yellowish red (5YR5/6) silty clay and clay, carbonate nodules

Reddish brown (5YR5/4) clayey silty fine sand, poorly sorted, 2.0-3.0 phi mode

Reddish brown (5YR5/4) silty fine sand, poorly sorted

Yellowish red (5YR4/6) clay

Brown (7.5YR5/4) clayey silty very fine sand

Dark brown to brown (7.5YR4/4) silty clay

Brown (7.5YR5/4) medium sand, ranging from medium to coarse sand, weakly carbonate cemented Brown (7.5YR5/4) medium sand, ranging from fine to medium sand, silty at top, fining upward

Brown (7.5YR5/4) medium sand, ranging from fine to coarse sand, silty sand interbeds, poorly sorted

Brown (7.5YR5/4) silty fine sand, poorly sorted, sandy clay laminations

Brown (7.5YR5/3) medium sand, 2.5-1.5 phi mode, reddish gray (7.5YR5/2) laminations

Brown (7.5YR5/4) silty fine sand, poorly sorted, massive

Brown (7.5YR5/4) and reddish brown (5YR5/4) silty clay, indistinctly laminated, low dry strength, nonplastic, white carbonate nodules

Reddish brown (5YR5/3) silty fine sand, poorly sorted, ranging from fine to coarse sand, bands of distinct carbonate cement

Reddish brown (5YR4/4) silty clay, discontinuously laminated, scattered soft carbonate nodules

Pinkish gray (5YR6/2) silt, laminated, microlaminated, dark mineral microlaminations, weakly carbonate cemented, unit coarsens upward

Yellowish red (5YR5/6) silty clay, carbonate nodules, irregular lenses, mottling

Light brown (7.5YR6/4) very fine sand, 2.5-2.0 phi mode, moderately sorted, carbonate cemented, strong $\mathrm{HCl}$ reaction

Yellowish red (5YR4/6) clay, indistinctly laminated, low dry strength, nonplastic, small scattered carbonate nodules, manganese staining

Reddish brown (5YR5/4) silty fine sand, poorly sorted, 2.0-3.0 phi mode, massive

Dark brown to brown (7.5YR4/4) silty clay and clay, thinly laminated

Strong brown (7.5YR5/6) silty fine sand, poorly sorted, 2.5-3.5 phi mode, clay, sand, silt interlaminae

Brown (7.5YR5/4) silty fine sand, poorly sorted, 3.5-3.0 phi mode, clay in upper unit, fining up unit

Brown (7.5YR5/4) silty fine sand, poorly sorted, 2.5-2.0 phi mode, ranging from fine to medium sand, indistinctly laminated

Brown (7.5YR5/4) silty clay, massive, low dry strength, nonplastic, massive

Brown (7.5YR5/4) silty fine sand, poorly sorted, 2.5-1.5 phi mode, ranging from fine to medium sand, distinct clay laminae

Dark brown to brown (7.5YR4/4) silty clay

Dark brown to brown (7.5YR4/4) silty clay, carbonate layer

Dark brown to brown (7.5YR4/4) silty clay, distinct yellowish brown (10YR5/4) clayey silt interbeds

Brown (7.5YR5/4) clay, indistinctly laminated, low dry strength, nonplastic, indistinct laminae of sandy silt Brown (7.5YR5/4) clayey silty fine sand, poorly sorted, 2.0-1.5 phi mode, ranging from fine to medium sand, clay laminae

Brown (7.5YR5/4) silty fine sand, poorly sorted, 2.0-1.5 phi mode, ranging from medium to coarse sand, poorly sorted, several basal silty clay laminae

Strong brown (7.5YR5/6) medium sand, 2.0-1.5 phi mode, ranging from very fine to medium sand, faintly laminated, reddish brown (5YR5/4) basal clay

Strong brown (7.5YR5/6) clayey silty fine sand, poorly sorted, 2.5-3.5 phi mode

Yellowish brown (10YR5/4) silty fine sand, poorly sorted, 2.0-1.5 phi mode, ranging from fine to medium sand; strong brown (7.5YR5/6) clayey silt laminae

Dark yellowish brown (10YR4/4) silty clay

Strong brown (7.5YR5/6) medium sand, 1.5-2.5 phi mode, ranging from fine to medium sand, well sorted Dark yellowish brown (10YR4/4) silty clay

Light brown (7.5YR6/4) medium sand, 2.0-3.0 phi mode, ranging from fine to medium sands, moderately sorted, carbonate nodules, coarsens down

Dark yellowish brown (10YR4/4) silty clay, indistinct silty laminae, carbonate nodules

Strong brown (7.5YR5/6) medium sand

Brown (7.5YR5/4) silty fine sand, poorly sorted, massive 
Strong brown (7.5YR5/6) silty fine sand, poorly sorted, 2.0-3.0 phi mode, sands ranging from fine to medium, scattered clayey silt laminae

$474.1 \quad 474.6$

$474.6 \quad 475.4$

$475.4 \quad 475.6$

$475.6 \quad 475.6$

$475.6 \quad 475.8$

$475.8 \quad 476.7$

$483.1 \quad 483.3$

$483.3 \quad 483.8$

$483.8 \quad 484.2$

$484.2 \quad 484.9$

$484.9 \quad 485.3$

$485.3 \quad 486.7$

$486.7 \quad 487.0$

$\begin{array}{ll}487.0 & 487.3\end{array}$

$488.8 \quad 489.0$

$489.0 \quad 490.1$

$490.1 \quad 490.3$

$490.3 \quad 490.5$

$490.5 \quad 490.5$

$490.5 \quad 490.6$

$490.6 \quad 490.7$

$490.7 \quad 491.3$

$491.3 \quad 491.4$

$491.4 \quad 491.5$

$491.5 \quad 492.4$

$492.7 \quad 493.4$

$493.4 \quad 494.7$

$494.7 \quad 494.7$

$494.7 \quad 494.9$

$494.9 \quad 495.4$

$495.4 \quad 495.8$

\begin{tabular}{ll}
$495.8 \quad 496.4$ \\
\hline
\end{tabular}

$\begin{array}{lll}497.7 & 498.7\end{array}$

$498.7 \quad 499.8$

$499.8 \quad 501.9$

$501.9 \quad 505.7$

$505.7 \quad 505.9$

$505.9 \quad 506.6$

$506.6 \quad 506.7$

$506.7 \quad 506.8$

Strong brown (7.5YR5/6) silty fine sand, poorly sorted, 3.5-3.0 phi mode, silt laminae

Dark brown to brown (7.5YR4/4) clayey fine sand, 4.0-3.5 phi mode, clay interlaminae and interbeds Light brown (7.5YR6/4) very fine sand, 3.0-4.0 phi mode, poorly sorted

Light brown (7.5YR6/4) fine to medium sand, poorly sorted

Brown (7.5YR5/4) clayey very fine sand, 4.0-3.5 phi mode, poorly sorted, massive

Brown (7.5YR5/4) medium sand, sands ranging from fine to coarse, poorly sorted, scattered clay laminae,

wet moisture condition

Dark brown to brown (7.5YR4-5/4) silty clay and reddish brown (5YR4/4) clay, homogeneous, silty clay at base and clay in upper unit

Strong brown (7.5YR5/6) fine sand, 3.0-2.5 phi, well sorted, weakly cemented, laminated, scattered soft carbonate nodules

Strong brown (7.5YR4/6) clayey sandy silt, 3.5-3.0 phi mode, sands range from fine to coarse, brown (7.5YR5/4) clay silt

Yellowish brown (10YR5/4) medium sand, 2.0-3.0 phi mode, sands ranging from fine to coarse, poorly sorted, silty laminae

Yellowish brown (10YR5/4) silty fine sand, poorly sorted, 3.5-3.0 phi mode, interlaminated brown (7.5YR5/4) clay layers

Light yellowish brown (10YR6/4) silty fine sand, poorly sorted, 3.0-2.0 phi mode, sands ranging from fine to medium, distinctly laminated, weakly carbonate cemented, heavy mineral laminations

Brown (7.5YR5/4) silty fine sand, poorly sorted, sands ranging from fine to medium, strong brown (7.5YR4/6) silt laminae

Brown (7.5YR5/4) fine sand

Brown (7.5YR5/4) silty clay

Brown (7.5YR5/4) medium sand, 2.0-1.5 phi mode, ranging from fine to medium sands, moderately sorted, red silty clay laminae

Reddish brown (5YR4-5/4) clay, silt, fine sand, interlaminated

Light brown to brown (7.5YR6-5/4) medium sand, sands ranging from fine to coarse, poorly sorted, weakly carbonate cemented

Reddish brown (5YR5/4) silty clay and clay, interlaminated

Light brown to brown (7.5YR6-5/4) medium sand, sands ranging from fine to coarse, poorly sorted, weakly carbonate cemented

Reddish brown (5YR5/4) silty clay and clay, interlaminated

Light brown to brown (7.5YR6-5/4) medium sand, sands ranging from fine to coarse, poorly sorted, weakly carbonate cemented

Reddish brown (5YR5/4) silt

Reddish brown (5YR5/4) silty clay

Light brown to brown (7.5YR6-5/4) medium sand, sands ranging from fine to coarse, poorly sorted, weakly carbonate cemented

Brown (7.5YR5/4) silty clay and clay, interbedded

Pink (7.5YR7/4) silty fine sand, poorly sorted, sands ranging from fine to medium, laminated, thinly bedded Pink (7.5YR7/4) silty fine sand, poorly sorted, sands ranging from fine to medium, laminated, thinly bedded, weakly carbonate cemented

Pink (7.5YR7/4) silty fine sand, poorly sorted, sands ranging from fine to medium, laminated, thinly bedded Light brown (7.5YR6/4) silty fine sand, poorly sorted, 3.5-3.0 phi mode, cross-laminated, heavy minerals, basal red clay interlaminae

Strong brown (7.5YR4/6) clay, indistinctly thinly bedded, low dry strength, nonplastic, bedded, basal soft carbonate nodules

Light brown (7.5YR6/4) silty fine sand, poorly sorted, 2.5-3.5 phi mode, basal red clay

Strong brown (7.5YR4/6) silty clay and clay, thinly bedded

Brown (7.5YR5/4) and strong brown (7.5YR4/6) clay, silty clay, very fine sand, thinly bedded

Brown (7.5YR5/4) silty fine sand, poorly sorted, 2.5-1.5 phi mode, sands ranging from fine to coarse, poorly sorted

Strong brown (7.5YR5/6) silty fine sand, poorly sorted, 2.0-1.5 phi mode, sands ranging from fine to medium, indistinctly flat laminated, scattered soft carbonate nodules

Reddish brown (5YR4/4) silty clay

Brown (7.5YR5/4) silty fine sand, poorly sorted, 2.5-2.0 phi mode, indistinctly laminated

Light brown (7.5YR6/4) very fine sandy silt

Light brown (7.5YR6/4) clayey silt 
$\begin{array}{ll}506.8 & 507.3\end{array}$

$\begin{array}{ll}507.3 & 507.7\end{array}$

$507.7 \quad 508.1$

$508.1 \quad 508.4$

$508.4 \quad 510.5$

$510.5 \quad 510.6$

$510.6 \quad 510.8$

$510.8 \quad 510.8$

$510.8 \quad 511.7$

$511.7 \quad 511.8$

$511.8 \quad 512.5$

$513.7 \quad 513.9$

$513.9 \quad 514.6$

$514.6 \quad 514.9$

\begin{tabular}{ll}
$514.9 \quad 515.2$ \\
\hline
\end{tabular}

$515.2 \quad 516.9$

$516.9 \quad 516.9$

$516.9 \quad 517.2$

$517.2 \quad 517.9$

$\begin{array}{ll}518.7 & 519.2\end{array}$

$519.2 \quad 520.8$

$520.8 \quad 521.5$

$521.5 \quad 522.7$

$\begin{array}{ll}522.7 & 522.9\end{array}$

$523.7 \quad 524.8$

$524.8 \quad 524.9$

$524.9 \quad 525.1$

$525.1 \quad 525.2$

$525.2 \quad 525.4$

$525.4 \quad 525.6$

$525.6 \quad 526.0$

$526.0 \quad 526.4$

$526.4 \quad 526.8$

$528.7 \quad 528.8$

$528.8 \quad 529.1$

$529.1 \quad 529.5$

$529.5 \quad 530.0$

$530.0 \quad 530.2$

530.2530 .3

$530.3 \quad 530.7$

$534.0 \quad 534.3$

$534.3 \quad 534.7$

Strong brown (7.5YR4/6) clay, silty clay bed, thin moderately cemented carbonate zone

Brown (7.5YR5/4) silty fine sand, poorly sorted, 2.5-2.0 phi mode, sands ranging from fine to medium

Yellowish brown (10YR5/4) silty fine sand, poorly sorted, 2.5-2.0 phi mode, sands ranging from fine to medium

Yellowish brown (10YR5/4) silty fine sand, poorly sorted, 2.5-2.0 phi mode, sands ranging from fine to medium, thin weakly cemented zone

Yellowish brown (10YR5/4) silty fine sand, poorly sorted, 2.5-2.0 phi mode, sands ranging from fine to medium

Yellowish red (5YR5/6) clayey silty fine sand, poorly sorted, massive, weakly cemented

Pink (5YR7/4) fine sand, weakly carbonate cemented

Yellowish red (5YR5/6) clayey silty fine sand, poorly sorted, massive, weakly cemented

Brown (7.5YR5/4) medium sand, 1.0-2.0 phi mode, sands ranging from fine to coarse, poorly sorted

Yellowish brown (10YR5/4) silty clay, low dry strength, nonplastic, laminated

Reddish brown (5YR4/4) silty clay and clay, fining up unit

Reddish brown (5YR4/4) silty clay and clay

Yellowish brown (10YR5/4) to strong brown (7.5YR5/6) clayey silty fine sand, poorly sorted, sands ranging from fine to coarse, massive

Yellowish brown (10YR5/4) silty fine sand, poorly sorted, 2.5-1.5 phi mode, sands ranging from fine to coarse, heavy dark mineral laminae, fining up unit

Yellowish brown (10YR5/4) clayey silty fine sand, poorly sorted, massive, weakly cemented

Yellowish brown (10YR5/4) silty fine sand, poorly sorted, 2.5-2.0 phi mode, sands ranging from fine to medium, , massive, weakly cemented, few soft carbonate nodules

Yellowish brown (10YR5/4) silty clay

Yellowish brown (10YR5/4) silty fine sand, poorly sorted, 3.0-2.5 phi mode, sands ranging from fine to medium, massive, weakly cemented

Yellowish brown (10YR5/4) fine sand, 3.0-2.0 phi mode, sand ranging from fine to coarse, poorly sorted, fining up unit

Yellowish brown (10YR5/4) to brown (7.5YR5/4) silty clay and clay, thinly laminated

Yellowish brown (10YR5/4) clayey silty fine sand, poorly sorted, and fine sand, 3.0-2.0 phi, interbedded, thinly bedded to thickly laminated

Yellowish brown (10YR5/4) silty medium sand, 2.5-1.5 phi mode, weakly cemented zones

Strong brown (7.5YR4/6) silty clay and clay

Brown (7.5YR5/4) fine sand, 1.5-1.0 phi mode, ranging from fine to coarse sand, poorly sorted

Strong brown (7.5YR5/6) silty fine sand, poorly sorted, sands ranging from fine to coarse, upward

fining unit at top

Strong brown (7.5YR5/6) silty fine sand, poorly sorted, sand ranging from fine to coarse, upward fining unit at top, weakly carbonate cemented zone

Strong brown (7.5YR5/6) silty fine sand, poorly sorted, sands ranging from fine to coarse, upward fining unit at top

Strong brown (7.5YR5/6) silty fine sand, poorly sorted, sands ranging from fine to coarse, upward fining unit at top, weakly carbonate cemented zone

Strong brown (7.5YR5/6) silty fine sand, poorly sorted, sands ranging from fine to coarse, upward fining unit at top

Strong brown (7.5YR5/6) silty fine sand, poorly sorted, sands ranging from fine to coarse, upward fining unit at top, weakly carbonate cemented zone

Yellowish brown (10YR5/46-4) clayey silty very fine sand, poorly sorted, massive, weakly cemented

Brown (7.5YR5/4) silty fine sand, poorly sorted, 3.0-2.5 phi mode, wet moisture condition

Brown (7.5YR5/4) clayey silty very fine sand, poorly sorted, massive, weakly cemented

Yellowish brown (10YR5/4) clayey silty very fine sand and clayey silt, interlaminated, poorly sorted, weakly cemented

Light yellowish brown (10YR6/4) fine sand, 2.5-2.0 phi mode, sands ranging from fine to medium, weakly carbonate cemented, heavy mineral laminations

Light brown (7.5YR6/4) to light yellowish brown (10YR6/4) clay, silt, very fine sand, interlaminated

Yellowish brown (10YR5/4) medium sand, 2.0-1.0 phi mode, sands ranging from fine to coarse, cross-laminated, well sorted

Yellowish brown (10YR5/4) clayey silty fine sand, poorly sorted and silty clay, interlaminated

Reddish brown (5YR4/4) clay, low dry strength, nonplastic, massive

Yellowish brown (10YR5/4) silty fine sand, poorly sorted, 2.5-2.0 phi mode, massive

Strong brown (7.5YR5-4/6) silty clay, red (5YR) 2 millimeter thick laminae

Light brown (7.5YR6/4) fine sand, 2.5-2.0 phi mode, ripple laminated, dark mineral laminae 
$\begin{array}{lll}534.7 & 534.7\end{array}$

$534.7 \quad 535.0$

$535.0 \quad 535.1$

535.1535 .3

$535.3 \quad 535.4$

$535.4 \quad 535.5$

$535.5 \quad 535.6$

$535.6 \quad 535.8$

$535.8 \quad 535.9$

$535.9 \quad 536.1$

536.1536 .3

$536.3 \quad 537.2$

$539.0 \quad 539.4$

$\begin{array}{ll}539.4 & 539.7\end{array}$

$\begin{array}{ll}539.7 & 541.7\end{array}$

$544.0 \quad 544.2$

$544.2 \quad 544.4$

$544.4 \quad 544.6$

$544.6 \quad 544.7$

$544.7 \quad 544.8$

$544.8 \quad 544.9$

$544.9 \quad 545.0$

$\begin{array}{ll}545.0 & 545.7\end{array}$

$545.7 \quad 546.0$

$546.0 \quad 546.5$

$546.5 \quad 546.7$

$546.7 \quad 546.8$

$546.8 \quad 547.6$

$547.6 \quad 547.9$

$549.0 \quad 549.3$

$549.3 \quad 549.4$

$549.4 \quad 549.5$

$549.5 \quad 549.6$

$549.6 \quad 549.8$

$549.8 \quad 550.0$

$550.0 \quad 550.5$

$550.5 \quad 551.3$

$551.3 \quad 551.4$

$551.4 \quad 551.8$

$551.8 \quad 552.2$

$554.0 \quad 554.5$

$554.5 \quad 555.0$

$555.0 \quad 555.6$

$555.6 \quad 556.0$

$559.0 \quad 560.8$

$560.8 \quad 561.1$

$561.1 \quad 561.4$

$561.4 \quad 561.7$

$561.7 \quad 561.8$

$561.8 \quad 562.0$

$562.0 \quad 562.4$
Brown (7.5YR5/4) silty clay

Light brown (7.5YR6/4) fine sand, 2.5-2.0 phi mode, ripple laminated, dark mineral laminae

Strong brown (7.5YR4/6) clay

Brown (7.5YR5/4) clayey sandy silt

Strong brown (7.5YR4/6) clay

Light brown (7.5YR6/4) fine sand, 2.5-2.0 phi mode, ripple laminated, dark mineral laminae

Brown (7.5YR5/4) silty clay

Light brown (7.5YR6/4) fine sand, 2.5-2.0 phi mode, ripple laminated, dark mineral laminae

Strong brown (7.5YR4/6) clay

Brown (7.5YR5/4) clayey sandy silt

Light brown (7.5YR6/4) silty fine sand, poorly sorted, 2.5-2.0 phi mode, sands ranging from fine to coarse, crosslaminated, dark mineral

Light brown (7.5YR6/4) fine sand, 2.5-2.0 phi mode, ripple laminated, dark mineral laminae

Yellowish brown (10YR5/4) silty fine sand, poorly sorted, ranging from fine to medium sand; brown

(7.5YR5/4) silty clay laminae

Yellowish red (5YR4/6) silty sandy clay, fining up to silty clay

Reddish brown (5YR4/4) to brown (7.5YR5/4) silty clay and clay, thin silty partings, fining up unit, basal clayey sandy silt

Strong brown (7.5YR4/6) clay

Dark brown to brown (7.5YR4/4) silty clay

Light yellowish brown (10YR6/4) silty fine sand, poorly sorted, 3.0-2.0 phi mode, laminated

Strong brown (7.5YR4/6) clay, laminated, low dry strength, nonplastic

Reddish yellow (7.5YR6/6) to strong brown (7.5YR5/6) clayey sandy silt

Light yellowish brown (10YR6/4) clayey silt

Dark brown to brown (7.5YR4/4) to pale brown (10YR6/4) clay, low dry strength, nonplastic, finely

laminated

Strong brown (7.5YR5/6) silty clay and clay, massive, low dry strength, nonplastic, basal laminations

Yellowish brown (10YR5/6) clayey silt, massive

Brown (7.5YR5/4) to strong brown (7.5YR5/6) sandy clayey silt, massive

Brown (7.5YR5/4) medium sand, sand ranging from fine to coarse, poorly sorted

Brown (7.5YR5/4) clayey silty very fine sand

Strong brown (7.5YR5/6) clayey silty very fine sand, poorly sorted, massive, weakly cemented

Brown (7.5YR5/4) clayey silty fine sand, poorly sorted

Strong brown (7.5YR5/6) silty fine sand, poorly sorted, 3.5-2.5 phi mode, indistinct flat laminae

Light gray (10YR7/2) medium sandstone, grain size ranging from medium to coarse, strongly carbonate

cemented, strong reaction to $\mathrm{HCl}$

Brown (7.5YR5/4) silty fine sand, poorly sorted, 3.0-2.5 phi mode, indistinct laminae

Pale brown (10YR6/3) sandy clayey silt and silty clay, interlaminated

Brown (10YR5/3) and yellowish red (5YR4/6) silty clay and clay, interlaminated, microlaminated

Light gray (10YR7/2) fine sandstone, moderately sorted, strongly carbonate cement

Brown (10YR5/3) and yellowish red (5YR4/6) silty clay and clay, interlaminated, microlaminated

Yellowish red (5YR4/6) silt and silty clay, thinly bedded, indistinctly laminated

Light yellowish brown (10YR6/4) silty fine sand, poorly sorted, 2.5-2.0 phi mode

Yellowish brown (10YR5/4) silty clay, laminated

Yellowish brown (10YR5/4) clayey silty very fine sand, laminated

Brown (7.5YR5/4) fine sand, 2.5-2.0 phi mode, grain size ranging from fine to coarse

sand, faintly horizontally bedded, clean

Reddish brown (5YR5/4) and yellowish brown (10YR5/4) clayey silty fine sand, poorly sorted and red

clay, mottled together, not laminated

Reddish brown (5YR5/4) and pale brown (10YR6/3) silty clay, silt and clay, interbedded, microlaminated

Reddish brown (5YR4/4) clay, interbedded silty laminae

Yellowish red (5YR4/6) silty clay and clay, low dry strength, nonplastic, thinly bedded to microlaminated

Dark brown to brown (7.5YR4/4) silty clay, microlaminated at top

Yellowish brown (10YR5/4) silty fine sand, poorly sorted, 3.0-1.5 phi mode, ranging from fine to medium sand, cross-laminated, thick silty clay laminae

Yellowish brown (10YR5/4) silty fine sand, poorly sorted, 3.0-2.5 phi mode, laminated

Yellowish brown (10YR5/4) fine sandstone, 3.0-2.5 phi mode, strongly carbonate cemented, strong reaction to $\mathrm{HCl}$

Yellowish brown (10YR5/4) silty fine sand, poorly sorted, 3.0-2.5 phi mode, laminated silt

Reddish brown (5YR4/4) clay, medium dry strength, low plasticity, laminated, microlaminated silt 


\begin{tabular}{|c|c|c|}
\hline 569.0 & 569.2 & Strong brown (7.5YR4/6) sandy silty clay \\
\hline 569.2 & 569.4 & Brown (7.5YR5/4) silty fine sand, poorly sorted, numerous clayey silty laminae \\
\hline 69.4 & 569.6 & Pinkish gray (7.5YR6/2) silty fine sand, poorly sorted and strong brown (7.5YR4/6) silty clay, mottled \\
\hline 569.6 & 569.7 & Brown (7.5YR5/4) clayey silty fine sand, poorly sorted, massive, weakly cemented \\
\hline 569.7 & 570.1 & Dark red (2.5YR3/6) clay, low dry strength, nonplastic, massive, scattered pockets of sandy silt \\
\hline 70.1 & 570.2 & $\begin{array}{l}\text { Light yellowish brown (10YR6/4) medium sand, grain size ranging from fine to medium sand, weakly } \\
\text { carbonate cemented }\end{array}$ \\
\hline 72.7 & 573.3 & Reddish brown (5YR4/4) clay and light reddish brown (5YR6/4) silty clay, thinly bedded, laminated clays \\
\hline 73.3 & 573.4 & Light brown (7.5YR6/4) clayey sandy silt, red clay interlaminae \\
\hline 73.4 & 574.1 & Reddish brown (5YR4/4) clay and light reddish brown (5YR6/4) silty clay, thinly bedded, laminated clays \\
\hline 76.0 & 576.1 & $\begin{array}{l}\text { Brown ( } 7.5 Y R 5 / 4) \text { medium sandstone, quartz rich, strongly carbonate cemented, strong reaction to } \mathrm{HCl} \text {, } \\
\text { massive }\end{array}$ \\
\hline 76.1 & 576.3 & $\begin{array}{l}\text { Brown ( } 7.5 Y \mathrm{R} 5 / 4) \text { medium sandstone, grain size ranging from medium to coarse, strongly carbonate } \\
\text { cemented, strong reaction to } \mathrm{HCl} \text {, moderately sorted, massive }\end{array}$ \\
\hline 76.3 & 576.4 & Strong brown (7.5YR5/6) silty fine sand, poorly sorted, faint laminations \\
\hline 76.4 & 576.6 & $\begin{array}{l}\text { Reddish brown ( } 5 \text { YR } 4 / 4) \text { clay-clayey silt and yellowish brown (10YR5/4) and reddish yellow }(7.5 \text { YR6/6) } \\
\text { clayey silty very fine sand, thickly interlaminated }\end{array}$ \\
\hline 76.6 & 576.9 & Strong brown (7.5YR5/6) clayey sandy silt, massive, fining up to silty clay \\
\hline 576.9 & 577.2 & Yellowish red (5YR4/6) silty clay, massive, clay ripup intraclasts are platy in appearance \\
\hline 577.2 & 577.3 & Dark brown to brown (7.5YR4/4) clay, indistinctly laminated, low dry strength, nonplastic massive \\
\hline 93.4 & 593.6 & $\begin{array}{l}\text { Very pale brown (10YR7/3) fine sandstone, } 2.5-2.0 \text { phi mode, silt interbed, laminated, weakly carbonate } \\
\text { cemented }\end{array}$ \\
\hline 93.6 & 594.3 & Light brown (7.5YR6/4) fine sandstone, $2.5-2.0$ phi mode, indistinctly laminated to massive \\
\hline 94.3 & 596.8 & $\begin{array}{l}\text { Yellowish red ( } 5 \text { YR } 4 / 6) \text { and dark brown to brown ( } 7.5 \text { YR4/4) silty clay and clay, thinly bedded, } \\
\text { microlaminated }\end{array}$ \\
\hline 596.8 & 597.6 & Yellowish red (5YR5/6) sandy clayey silt, massive \\
\hline 597.6 & 597.7 & Light brown (7.5YR6/4) fine sand, 3.0-2.0 phi mode, grain size ranging from fine to coarse sand \\
\hline 597.7 & 597.8 & Yellowish red (5YR5/6) sandy clayey silt, massive \\
\hline 597.8 & 597.9 & Reddish yellow (7.5YR6/6) silty clay \\
\hline 597.9 & 598.6 & $\begin{array}{l}\text { Strong brown ( } 7.5 \text { YR5/6) silty fine sand, poorly sorted and clayey silt, interlaminated, sands ranging from } \\
\text { fine to medium }\end{array}$ \\
\hline 598.6 & 598.9 & Yellowish red (5YR5/6) silty clay, indistinctly laminated to massive \\
\hline 598.9 & 599.7 & $\begin{array}{l}\text { Yellowish red (5YR5/6), light brown ( } 7.5 \text { YR6/4), yellowish red (5YR4/6), light yellowish brown } \\
\text { (10YR6/4) clay, laminated, thinly bedded }\end{array}$ \\
\hline 99.7 & 600.0 & Reddish yellow (7.5YR6/6) clayey silty fine sand, poorly sorted and clayey silt, interbedded \\
\hline 600.0 & 601.0 & $\begin{array}{l}\text { Yellowish red (5YR5/6-8) silty clay, indistinctly laminated to massive, pockets of light yellowish brown } \\
\text { (10YR6/4) silty fine sand, poorly sorted }\end{array}$ \\
\hline 603.8 & 603.9 & Strong brown (7.5YR5/6) and yellowish red (5YR5/6) clay \\
\hline 603.9 & 604.6 & Yellowish brown (10YR5/4) silty clay and clay, low dry strength, nonplastic, laminated \\
\hline 604.6 & 604.9 & Brown (7.5YR5/4) clayey silty fine sand, poorly sorted, 3.0-2.0 phi mode \\
\hline 604.9 & 606.3 & Strong brown (7.5YR5/6) and yellowish red (5YR4/6) silty clay and clay, finely laminated to thinly bedded \\
\hline 606.3 & 606.8 & Reddish brown (5YR4/4) clay, low dry strength, nonplastic, massive \\
\hline 606.8 & 608.8 & $\begin{array}{l}\text { Yellowish brown (10YR5/4) and light yellowish brown (10YR6/4) silty sandy clay and clay, coarsening up } \\
\text { unit }\end{array}$ \\
\hline 608.8 & 609.4 & Yellowish brown (10YR5/4) silty fine sand, poorly sorted, grain size ranging from fine to medium \\
\hline 609.4 & 609.8 & Yellowish brown (10YR5/4) silty fine sand, poorly sorted, massive, weakly cemented \\
\hline 609.8 & 611.1 & Yellowish brown (10YR5/4) silty clay and clay, interlaminated \\
\hline 611.1 & 611.6 & Yellowish brown (10YR5/4) silty fine sand, poorly sorted, grain size ranging from fine to medium \\
\hline 611.6 & 613.1 & Yellowish brown (10YR5/4) silty clay and clay, interlaminated \\
\hline 613.1 & 613.3 & $\begin{array}{l}\text { Yellowish brown (10YR5/4-6) clayey silty very fine sand, 3.0-2.0 phi mode, poorly sorted, massive, weakly } \\
\text { cemented }\end{array}$ \\
\hline 613.3 & 614.8 & Reddish brown (5YR4/3) and brown (10YR5/3) silty clay and clay, laminated, thinly bedded \\
\hline 614.8 & 616.5 & Brown (10YR5/3) clayey silty fine sand, poorly sorted, 3.0-2.5 phi mode, thinly interbedded \\
\hline 616.5 & 617.1 & Light brown (7.5YR6/4) clay, fine sand and silt, 3.0-2.5 phi mode, interlaminated \\
\hline 617.1 & 617.4 & Reddish brown (5YR4/3) and brown (10YR5/3) silty clay and clay, laminated, thinly bedded \\
\hline 617.4 & 617.7 & Reddish brown (5YR4/4) and strong brown (7.5YR5/6) clay and silty clay, thinly bedded \\
\hline 617.7 & 619.2 & $\begin{array}{l}\text { Brown (7.5YR5/4) silty fine sand, poorly sorted, } 2.5-2.0 \text { phi mode, sands ranging from fine to coarse, } \\
\text { indistinctly laminated, scattered granules }\end{array}$ \\
\hline & & Reddish brown (5YR4/4) and strong brown (7.5YR5/6) clay and s \\
\hline 193 & 621.5 & Reddish brown (5YR4/4) and strong brown (7.5YR5/6) clay, silty clay, sandy clayey silt beds, thinly \\
\hline
\end{tabular}


bedded

$621.5623 .5 \quad$ Yellowish red (5YR5/6) silty clay and clay, laminated, thinly bedded, small gray (5YR5/1) ripup clasts

Brown (10YR5/3) clayey sandy silt, thinly interbedded

$624.1 \quad 624.6$

$624.6 \quad 624.8$

Brown (10YR5/3) to yellowish brown (10YR5/4) medium sand, 2.5-2.0 phi mode, sands ranging from fine to coarse sand, poorly sorted, small soft carbonate nodules

Very dark gray (10YR3/1) clayey sandy silt, organic layer

624.8 625.2 Pale brown (10YR6/3) medium sand, 2.0-1.5 phi mode, grain size ranging from fine to coarse, poorly sorted, basal weakly carbonate cemented

$625.4 \quad 625.5$

$625.5 \quad 625.9$

Brown (7.5YR5/4) silty fine sand, poorly sorted, sands ranging from fine to coarse,

625.9626 .1 clay laminae

626.1626 .3

Brown (1OYRS/3) silty clay and clayey silt, interbedded

$626.3 \quad 626.5$

rich at top, coarsening up unit

$631.5 \quad 632.5$

$632.5 \quad 633.0$

$633.0 \quad 633.4$

$634.4 \quad 635.9$

$635.9 \quad 636.5$

Brown (7.5YR5/4) medium sand, grain size ranging from fine to coarse

Brown (7.5YR5/2) silty very fine sand and silty clay, interlaminated to thinly interbedded

Yellowish red (5YR5/6) clay, low dry strength, nonplastic, wavy laminations

Brown (10YR5/3) silty fine sand, poorly sorted, sands ranging from fine to coarse, laminated, thinly bedded

635.9636 .5

$636.5 \quad 637.2$

$637.2 \quad 637.5$

$637.5 \quad 638.0$

$638.0 \quad 638.6$

$638.6 \quad 638.9$

Brown (10YR5/3) silty fine sand, poorly sorted, grain size ranging from fine to medium sand, massive

Brown (10YR5/3) silty fine sand, poorly sorted, ranging from fine to medium sand, moderately carbonate cemented, indistinctly laminated

Brown (10YR5/3) clayey silty very fine sand and sandy clayey silt, thinly interbedded

Dark brown to brown (10YR4/3) clayey silty fine sand, poorly sorted, massive, weakly cemented

Dark brown to brown (10YR4/3) clayey sandy silt, indistinctly laminated

Dark yellowish brown (10YR4/4) clayey silty fine sand, poorly sorted, indistinctly laminated

638.9639 .1

$639.1 \quad 639.2$

$639.2 \quad 639.3$

$639.3 \quad 639.8$

$641.4 \quad 641.9$

$641.9 \quad 642.3$

$642.3 \quad 642.8$

$642.8 \quad 643.1$

643.1643 .6

Dark brown to brown (10YR4/3) silty fine sand, poorly sorted, ranging from fine to medium sand, basal ironoxide staining

Dark brown to brown (10YR4/3) silty fine sand, poorly sorted, ranging from fine to coarse sand

Dark yellowish brown (10YR4/4) silt and silty clay, massive

Brown (10YR5/3) sandy silt

Brown (10YR5/3) clayey silty very fine sand, poorly sorted, massive, weakly cemented

Brown (7.5YR5/4) silty fine sand, poorly sorted, grain size ranging from fine to medium sand, massive

Dark brown to brown (7.5YR4/4) sandy silty clay

Dark brown to brown (7.5YR4/4) silty clay

Brown (7.5YR5/4) clayey sandy silt, massive

$643.6 \quad 643.7$

Brownish yellow (10YR6/6) silty fine sand, poorly sorted, and silty clay, interlaminated, sands ranging fromfine to medium grain size

$649.0 \quad 649.8$

Light brown (7.5YR6/4) clayey silt and silty clay to pale brown (10YR6/3) basal medium to coarse sand,

fining up unit

$\begin{array}{ll}649.8 \quad 650.8 \\ 650.8 & 650.9\end{array}$

$\begin{array}{ll}650.8 & 650.9\end{array}$

$650.9 \quad 651.2$

$651.2 \quad 651.3$

$651.3 \quad 651.6$

$651.6 \quad 651.8$

Yellowish brown (10YR5/4) and brown (7.5YR5/4) clayey silt, silty clay, clayey silty sand, thinly bedded, mottled

Yellowish brown (10YR5/4) silty fine sand, poorly sorted, 2.5-2.0 phi mode, laminated

Brown (10YR5/3) and pale brown (10YR6/3) clayey silt and clay, interlaminated

Yellowish brown (10YR5/4) to light gray (10YR7/2) silty fine sand, poorly sorted, 2.5-2.0 phi mode

Very pale brown (10YR7/3) gravelly coarse sand, 2.0-1.0 phi mode, poorly sorted

Brown (10YR5/3) silty clay and silty very fine sand, 2.5-2.0 phi mode, interlaminated

$656.0 \quad 656.2$

Brown (10YR5/3) gravelly coarse sand, grain size ranging from fine to coarse, well sorted, weakly carbonate cemented

$656.0 \quad 656.2$

Pinkish gray (7.5YR6/2) medium sand, 2.5-2.0 phi mode, ranging from fine to medium sand, moderately sorted, scattered feldspar

656.2658 .1

Yellowish brown (10YR5/4) and dark brown to brown (7.5YR4/4) silty clay and clay, thinly indistinctly laminated

$658.1 \quad 658.4$

$658.4 \quad 660.2$

$660.2 \quad 662.2$

$662.2 \quad 662.3$

$662.3 \quad 663.8$

$663.8 \quad 664.9$

Pinkish gray (7.5YR6/2) silty fine sand, poorly sorted, indistinctly laminated

Yellowish brown (10YR5/4) and dark brown to brown (7.5YR4/4) silty clay and clay, thinly indistinctly laminated

Pinkish gray (7.5YR6/2) medium sand, ranging from medium to coarse sand, strongly ripple laminated Pinkish gray (7.5YR6/2) medium sand, ranging from fine to coarse sand, strongly ripple laminated, loose Brown (7.5YR5/4) silty clay and light gray (10YR7/2) fine sand, 3.0-2.0 phi mode, laminated, deformed Pale brown (10YR6/3) to light brownish gray (10YR6/2) fine sand, 3.0-2.5 phi mode 
668.0670 .2 Brown (10YR5/3) and yellowish brown (10YR5/4) medium sand, ranging from fine to coarse sand, poorly sorted, indistinctly laminated, compact, mottled

670.3 670.4 Dark yellowish brown (10YR4/4) silty fine sand, poorly sorted and silt, 3.0-2.0 phi mode, sands ranging fromfine to coarse, laminated

$670.4 \quad 670.5 \quad$ Dark yellowish brown (10YR4/4) silt

670.5 671.0 Light yellowish brown (10YR6/4) silty fine sand, poorly sorted, 3.0-2.0 phi mode, sands ranging from fine to coarse

$671.0 \quad 671.6$

$671.6 \quad 671.8$

Yellowish brown (10YR5/4) clayey sand and silty clayey sand, thinly bedded

$671.8 \quad 672.4$

Dark brown to brown (7.5YR4/4) and yellowish brown (10YR5/4) silty clay

$672.4 \quad 672$

Yellowish brown (10YR5/4) silty medium sand, 2.5-1.5 phi, sands ranging from fine to medium, few silt clay laminae

$672.7 \quad 672.9$

Yellowish red (5YR4/6) and yellowish brown (10YR5/4) silty clay, low dry strength, nonplastic, microlaminated

672.9673 .9

Yellowish brown (10YR5/4) silty fine sand, poorly sorted, massive, weakly cemented

676.3676 .9

Yellowish red (5YR4/6) and yellowish brown (10YR5/4) silty clay, microlaminated

Yellowish brown (10YR5/4) and strong brown (7.5YR5/6) sandy clayey silt and silty clay

676.9677 .1

Yellowish brown (10YR5/4) medium sandstone, 2.5-2.0 phi mode, grain size ranging from fine to coarse, strongly carbonate

$678.5 \quad 679.0$

Strong brown (7.5YR4/6) silty fine sand, poorly sorted, $2.5-2.0$ phi mode

$679.0 \quad 679.4$

Dark brown to brown (7.5YR4/4) clayey silty fine sand, poorly sorted and yellowish red (5YR4/6) clay, interlaminated

$679.4 \quad 679.8$

Brown (7.5YR5/2-4) clayey silt and silty clay, interlaminated, thinly bedded

$679.8 \quad 680.4$

Brown (7.5YR5/2) silty fine sand, poorly sorted, 2.5-2.0 phi mode, loose

$680.6 \quad 680.9$

Light yellowish brown (10YR6/4) silty fine sand, poorly sorted, ranging from fine to coarse sand, laminated

$680.9 \quad 681.1$

Light yellowish brown (10YR6/4) medium sand, ranging from fine to coarse sand, weakly carbonate cemented

$681.1 \quad 681.5$

$692.7 \quad 693.3$

693.3696 .6

Light yellowish brown (10YR6/4) medium sand, grain size ranging from fine to medium sand

Dark brown to brown (7.5YR4/4) silty clay, massive, low dry strength, nonplastic

Light brown (7.5YR6/4) fine sand, 2.5-2.0 phi mode, laminated, ripple laminated, brown (10YR5/3) silt laminations

$697.4 \quad 697.5$

Pink (7.5YR7/4) medium sand, ranging from fine to coarse sand, weakly carbonate cemented

697.5698 .0

Pale brown (10YR6/3) fine sand, silty sand, dark brown to brown (10YR4/3) silty clay, sands ranging from fine to medium grain size, interbedded

$698.0 \quad 698.1 \quad$ Dark brown to brown (10YR4/3) silty clay

698.1 698.3 Brown (10YR5/3) fine sand, 2.5-1.5 phi mode, ranging from fine to coarse sand, massive, moderately sorted

$702.5 \quad 702.8$

$702.8 \quad 703.5$

703.5703 .6

703.6704 .1

$704.1 \quad 705.2$

705.2706 .5

$706.5 \quad 708.2$

$708.2 \quad 708.7$

$708.8 \quad 710.2$

Brown (7.5YR5/3) medium sand, grain size ranging from fine to coarse sand, laminated, poorly sorted

Brown (7.5YR5/3) medium sand, grain size ranging from fine to coarse sand, laminated, poorly sorted, thin interbeds of brown (10YR5/3) and dark brown to brown (10YR4/3) silty clay

Brown (7.5YR5/2) silty clay

Brown (7.5YR5/3) silty fine sand, poorly sorted, thin interlaminae of clayey silt

Dark yellowish brown (10YR4/4) silty clay, massive, low dry strength, nonplastic, upper laminations

Dark yellowish brown (10YR4/4) clayey sandy silt, thin interbeds of silty clay

Brown (10YR5/3) clayey silty very fine sand

Grayish brown (10YR5/2) clayey silty fine sand, poorly sorted, and brown (10YR5/3) silty clay and clay, mottled

$710.2 \quad 710.5$

$710.5 \quad 712.7$

$712.7 \quad 712.8$

$712.8 \quad 712.9$

$712.9 \quad 714.3$

$714.3 \quad 714.5$

Yellowish brown (10YR5/4) to dark yellowish brown (10YR4/4) silty clay, low dry strength, nonplastic,

laminated

Dark grayish brown (2.5Y4/2) silty fine sand, poorly sorted, 3.0-2.5 phi mode

Grayish brown (2.5Y5/2) silty fine sand, poorly sorted and clayey silt, 3.0-2.5 phi mode, interlaminated to thinly interbedded

White (10YR8/1) fine sandstone, strongly carbonate cemented, strong reaction to $\mathrm{HCl}$

White (10YR8/1) fine sand, moderately carbonate cemented

Dark grayish brown (2.5Y4/2) and dark brown to brown (7.5YR4/4) silty clay, medium dry strength, low plasticity, laminated, mottled, clay is sticky

$714.5 \quad 716.1$

$716.9 \quad 722.4$

Light brownish gray (10YR6/2) fine sand, 2.5-2.0 phi mode, moderately sorted, laminated

Dark grayish brown (2.5Y4/2) and dark brown to brown (7.5YR4/4) silty clay, laminated, mottled, clay is sticky

$722.4 \quad 723.5$

Dark grayish brown (2.5Y4/2) silty clay, laminated, mottled, soft sediment deformation

Light olive brown (2.5Y5/4) to grayish brown (2.5Y5/2) silty clay 
723.5 723.9 Light gray (10YR7/2) medium sand, 2.0-1.5 phi mode, ranging from fine to medium sand, moderately sorted, weakly carbonate cemented, loose upper unit

Light gray (10YR7/2) dry to light brownish gray (10YR6/2) medium sandstone, 2.0-1.5 phi mode, strongly carbonate cemented, strong reaction to $\mathrm{HCl}$, wet moisture condition, voids present

$734.5 \quad 734.7$ Light gray (10YR7/2) dry to light brownish gray (10YR6/2) medium sandstone, 2.0-1.5 phi mode strongly carbonate cemented, strong reaction to $\mathrm{HCl}$, wet moisture condition, voids present

$742.0 \quad 744.8$ Light brownish gray (2.5Y6/2) silty fine sand, poorly sorted, crosslaminated, few carbonate-rich zones Light brownish gray (2.5Y6/2) silty fine sand, poorly sorted, crosslaminated, weakly carbonate cemented Grayish brown (2.5Y5/2) silty fine sand, poorly sorted, 2.0-3.0 phi mode, ranging from fine to medium sand, crosslaminated, locally irregularly strongly cemented

$748.2 \quad 749.2$ Light olive brown (2.5Y5/4) silty fine sand, poorly sorted, and clayey silty fine sand, poorly sorted, 3.0-2.5 phi mode, thinly bedded Light olive brown (2.5Y5/4) silty clay, massive, medium dry strength, low plasticity Gray to light gray (2.5Y6/0) silty clay and clay, microlaminated Dark grayish brown (2.5Y4/2) and gray to light gray (2.5Y6/0) silty fine sand, poorly sorted and sandy silt, 3.0-2.5 phi mode, mottled

Dark grayish brown (2.5Y4/2) silty clay, massive, low dry strength, nonplastic

Gray $(2.5 Y 5 / 0)$ silty fine sand, poorly sorted, massive, weakly cemented

Yellowish brown (10YR5/4) to dark yellowish brown (10YR4/4) clayey silty fine sand, poorly sorted, massive

Brownish yellow (10YR6/6) silty fine sand, poorly sorted, indistinctly laminated

Yellowish brown (10YR5/6-4) silty clay and silty sand, interbedded

Yellowish brown (10YR5/6-4) silty clay

Brown (10YR5/3) fine sand, 2.5-2.0 phi mode, indistinctly bedded

Brown (10YR5/3) fine sandstone, 2.5-2.0 phi mode, strongly carbonate cemented, strong reaction to $\mathrm{HCl}$

Yellowish brown (10YR5/4) silty clay

$769.0 \quad 770.5$

$770.5 \quad 771.8$

Brown (10YR5/3) silty fine sand, poorly sorted, ranging from fine to medium sand, massive, loose,

Yellowish brown (10YR5/4) silty fine sand, poorly sorted, 2.5-2.0 phi mode, moderately carbonate cemented layers

$775.1 \quad 776.5$

$776.5 \quad 776.6$

$\begin{array}{ll}776.6 & 778.1\end{array}$

$778.1 \quad 778.2$

$\begin{array}{ll}782.0 & 782.3\end{array}$

$782.3 \quad 783.4$

$783.4 \quad 783.5$

$783.5 \quad 783.7$

$783.7 \quad 783.9$

$783.9 \quad 784.5$

$784.5 \quad 784.5$

$784.5 \quad 784.7$

$784.7 \quad 785.5$

$789.0 \quad 798.1$

$\begin{array}{ll}799.1 & 799.3\end{array}$

$799.3 \quad 803.4$

803.4804 .1

804.1805 .0

Yellowish brown (10YR5/4) medium sand, 2.0-1.5 phi mode, moderately sorted, laminated, crossbedded

Yellowish brown (10YR5/4) silty fine sand, poorly sorted, 2.5-2.0 phi mode, soft carbonate nodules

Yellowish brown (10YR5/4) medium sand, 2.0-1.5 phi mode, ranging from fine to coarse sand, poorly sorted

Pebble gravel

Dark brown to brown (7.5YR4/4) silty sand, moderately cemented, soft carbonate nodules

Yellowish brown (10YR5/4) silty fine sand, poorly sorted, ranging from fine to medium sand, loose

Brown (7.5YR5/4) clayey silt, basal caliche nodules

Brown (7.5YR5/4) clayey very fine sandy silt

Reddish brown (5YR5/4) clay

Brown (7.5YR5/4) clayey very fine sandy silt

Reddish brown (5YR5/4) clay, irregularly carbonate-cemented

Brown (7.5YR5/4) clayey very fine sandy silt

Reddish brown (5YR5/4) clay

Brown (7.5YR5/4) clayey very fine sandy silt

Light brownish gray (10YR6/2) medium sand, 2.0-1.5 phi mode, ranging from fine to medium sand Brown (7.5YR5/4) medium sand, 2.0-1.5 phi mode, crossbedded, scattered moderately carbonatecementated

Brown (7.5YR5/4) medium sand, 2.5-1.5 phi mode, ranging from fine to medium sand, caliche zone Brown (7.5YR5/4) medium sand, 2.5-1.5 phi mode, ranging from fine to medium sand

Brown (7.5YR5/4) medium sand, 2.0-1.5 phi mode

Brown (7.5YR5/4) fine sand, 2.5-2.0 phi mode, massive

807.7808 .8

$808.8 \quad 809.2$

Light brown (7.5YR6/4) wet to pinkish white (7.5YR8/2) medium sand, 2.0-1.5 phi mode, indistinctly laminated, dry moisture condition

$812.5 \quad 821.2$ Light brown (7.5YR6/4) wet to pinkish white (7.5YR8/2) medium sand, 2.0-1.5 phi mode, indistinctly laminated, moderately cemented, dry moisture condition

$822.0 \quad 824.0$

Pale brown (10YR6/3) medium sand, 2.0-1.5 phi, ranging from fine to coarse sand, indistinctly bedded, indistinct soft carbonate nodules

$824.0 \quad 824.9$ Brown (10YR5/3) medium sand, 2.0-1.0 phi mode, ranging from medium to coarse sand, indistinctly bedded, moderately sorted, soft carbonate nodules Brown (10YR5/3) gravelly coarse sand, wash out zones 
$824.9 \quad 825.1$

$825.1 \quad 825.9$

$832.0 \quad 832.2$

$832.2 \quad 832.4$

$832.4 \quad 832.5$

$832.5 \quad 832.9$

$842.0 \quad 842.7$

$\begin{array}{ll}842.7 & 842.8\end{array}$

$842.8 \quad 843.1$

$843.1 \quad 844.2$

848.7849 .1

$849.7 \quad 849.9$

$849.9 \quad 852.7$

$859.7 \quad 859.9$

$859.9 \quad 860.1$

$860.1 \quad 860.3$

$860.3 \quad 860.6$

$869.1 \quad 869.8$

$869.8 \quad 870.4$

$\begin{array}{ll}870.4 & 870.9\end{array}$

$879.1 \quad 879.3$

$879.3 \quad 879.4$

$879.4 \quad 879.6$

$879.6 \quad 879.9$

$879.9 \quad 880.5$

$880.5 \quad 880.7$

$889.1 \quad 889.4$

$889.4 \quad 890.2$

$890.2 \quad 890.5$

$890.5 \quad 890.7$

$893.1 \quad 894.5$

$894.5 \quad 894.7$

$894.7 \quad 894.9$

$894.9 \quad 895.5$

$902.0 \quad 902.7$

$909.5 \quad 909.8$

$909.8 \quad 910.7$

$913.7 \quad 914.9$

$914.9 \quad 915.9$

$915.9 \quad 916.8$

916.8917 .0

$917.0 \quad 917.2$

$917.9 \quad 919.9$

$919.9 \quad 922.5$

$929.3 \quad 930.3$

Brown (10YR5/3) gravel, angular pebble gravel with basalt, wash out zone

Brown (10YR5/3) medium sand, 2.5-1.5 phi mode, grain size ranging from fine to medium sand

Dark brown to brown (7.5YR4/4) clayey medium sand, ranging from medium to coarse sand

Pinkish gray (7.5YR7/2) medium sand, weakly carbonate cemented

quartzite gravel, washout zone

Brown (7.5YR5/4) gravelly medium sand, ranging from medium to coarse sand, scattered

pebbles and moderately cemented carbonate nodules

Dark brown to brown (7.5YR4/4) medium sand, 1.5-1.0 phi mode, ranging from medium to very coarse sand, few granules

Pebble gravel, rounded to subangular and fractured, matrix washed away, chert, basalt, quartz, granite

Brown (7.5YR5/4) medium sand, 2.5-1.5 phi mode, carbonate nodules

Brown (7.5YR5/4) coarse sand, moderately sorted, loose, and granules

Brown (7.5YR5/2) gravelly coarse sand, ranging from fine to coarse sand, poorly sorted

Pinkish gray (7.5YR7/2) medium sandstone, grain size ranging from fine to medium sand, scattered granules and small pebbles, poorly sorted, ash pebbles(?)

Brown (7.5YR5/4) medium sand matrix, ranging from fine to medium sand, scattered pebbles, volcanics, basalt, quartzite, discontinuous carbonate zones

Dark brown to brown (7.5YR4/4) coarse sand, moderately sorted, moderately cemented, $\mathrm{HCl}$ reaction none Brown (7.5YR5/4) mudstone, few matrix-supported pebbles

Pebble gravel and loose pebbles, quartzite, basalt, silicic metamorphic

Brown (7.5YR5/2) medium sand, ranging from fine to coarse sand, loose

Dark brown to brown (10YR4/3) fine sand, 3.0-2.0 phi mode, ranging from fine to medium sand, laminated, heavy minerals

Dark brown to brown (10YR4/3) fine sand, 3.0-2.0 phi mode, ranging from fine to medium sand, laminated, moderately cemented, heavy minerals

Dark brown to brown (10YR4/3) medium sand, 2.0-1.5 phi mode, ranging from fine to coarse sand, massive Brown (7.5YR5/2) medium sandstone, ranging from medium to very coarse sand, $\mathrm{HCl}$ reaction none, strongly carbonate cemented, strong reaction to $\mathrm{HCl}$

Reddish brown (5YR4/4) clay, indistinctly laminated, low dry strength, nonplastic, abundant carbonate nodules

Dark brown to brown (10YR4/3) silty clay, low dry strength, nonplastic, massive

Dark brown to brown (10YR4/3) silty fine sand, poorly sorted, compact, massive

Yellowish brown (10YR5/4) medium sand, ranging from fine to coarse sand, compact, granules

Dark brown to brown (10YR4/3) silty clay, dense

Yellowish brown (10YR5/4) medium sand, ranging from fine to coarse sand

Yellowish brown (10YR5/4) fine sand, ranging from fine to coarse sand

Yellowish brown (10YR5/4) gravelly coarse sand, ranging from fine to coarse sand, poorly sorted, irregular weakly carbonate cement zones

Yellowish brown (10YR5/4) medium sand, ranging from fine to coarse sand

Yellowish brown (10YR5/4) medium sand, ranging from fine to medium sand, basal scattered soft carbonate nodules, massive

Yellowish brown (10YR5/6) medium sand, basal soft carbonate nodules, massive

Yellowish brown (10YR5/4) fine sand, ranging from fine to medium sand, weakly carbonate cemented

Brown to pale brown (10YR6-5/3) medium sand, well compacted, weakly cemented

Pale brown (10YR6/3) medium sand, ranging from fine to coarse sand, strongly cemented, strong reaction to $\mathrm{HCl}$, soft carbonate nodules

Yellowish brown (10YR5/4) medium sand, ranging from fine to coarse sand, granules and pebbles, carbonate rich

Yellowish brown (10YR5/4) medium sand, ranging from fine to coarse sand, compact

Brown (7.5YR5/4) gravelly coarse sand, medium sand matrix, cross-bedded

Brown (7.5YR5/4) fine sand, 2.5-2.0 phi mode, ranging from fine to medium sand, scattered granules, cross-bedded

Brown (7.5YR5/4) gravelly coarse sand, grains size ranging from medium to coarse sand, massive

Brown (7.5YR5/4) gravelly coarse sand, ranging from medium to coarse, massive, white moderately carbonate cemented

Brown (7.5YR5/4) coarse sand, ranging from fine to coarse sand, granules, small pebbles

Yellowish brown (10YR5/4) fine sand, cross-laminated, flat laminated, well iron cemented laminae

Yellowish brown (10YR5/4) medium sand, grain size ranging from fine to coarse sand, cross-laminated, heavy mineral laminations, coarsens toward base

Yellowish brown (10YR5/4) fine sand, flat laminated, heavy minerals 
$930.3 \quad 930.6$

$930.6 \quad 930.8$

$930.8 \quad 931.0$

$931.0 \quad 932.1$

$932.1 \quad 932.5$

$932.5 \quad 932.6$

$932.6 \quad 932.8$

$932.8 \quad 933.7$

$942.0 \quad 942.7$

$942.7 \quad 942.8$

$942.8 \quad 945.9$

$945.9 \quad 946.2$

$946.2 \quad 977.0$

$977.0 \quad 977.3$

$977.3 \quad 978.5$

$978.5 \quad 979.3$

$979.3 \quad 980.2$

$980.2 \quad 980.8$

$980.8 \quad 981.4$

$982.0 \quad 982.6$

$982.6 \quad 1002.0$

1002.01003 .1

1003.11004 .6

1004.61005 .0

$1017.0 \quad 1017.5$

1017.51019 .3

$1022.0 \quad 1022.5$

$1022.5 \quad 1022.8$

$1022.8 \quad 1023.2$

$1031.0 \quad 1031.4$

1031.41031 .8

$1031.8 \quad 1032.1$

$1032.1 \quad 1033.0$

1033.01034 .1

1035.41035 .5

1035.51036 .7

$1036.7 \quad 1036.5$

1036.51036 .7

1036.71038 .1

$1042.0 \quad 1043.0$

$1043.0 \quad 1043.4$

1043.41043 .9

1043.91044 .0

$1044.0 \quad 1044.3$
Yellowish brown (10YR5/4) fine sand, flat laminated, heavy minerals

Yellowish brown (10YR5/4) silty fine sand, poorly sorted, weak carbonate cement

Yellowish brown (10YR5/4) silty fine sand, poorly sorted, weak carbonate cement, loose

Yellowish brown (10YR5/4) fine sand, $2.5-2.0 \mathrm{phi}$, indistinctly laminated

Yellowish brown (10YR5/4) fine sand, 2.5-2.0 phi mode, indistinctly laminated, moderately carbonate cemented

Yellowish brown (10YR5/4) medium sand, ranging from fine to coarse sand, massive, light yellowish brown (10YR6/4) carbonate cementation, loose sand intervals

Yellowish brown (10YR5/4) coarse sand, ranging from medium to coarse sand, loose, massive, light yellowish brown (10YR6/4) moderately carbonate cemented

Yellowish brown (10YR5/4) medium sand, ranging from fine to coarse sand, massive, light yellowish brown (10YR6/4) moderately carbonate cemented

Light yellowish brown (10YR6/4) medium sand, 2.5-2.0 phi mode, massive

Light yellowish brown (10YR6/4) medium sand, 2.5-2.0 phi mode, massive, moderately carbonate cemented

Light yellowish brown (10YR6/4) medium sand, 2.5-2.0 phi mode, massive

Grayish brown (10YR5/2) medium sandstone, massive, strongly carbonate cemented, strong reaction to $\mathrm{HCl}$

Grayish brown (10YR5/2) medium sand, massive

Light yellowish brown (10YR6/4) clayey silt, laminated, very compact

Yellowish brown (10YR5/4) silty fine sand, poorly sorted, very compact, clayey silty layer

Brown (10YR5/3) clayey silt, laminated, very compact

Dark brown to brown (7.5YR4/4) and brown (10YR5/3) silty clay and clay, thinly interbedded

Brown (10YR5/3) sandy clayey silt, distorted laminations

Pale brown (10YR6/3) medium sand, ranging from fine to coarse sand, weakly cemented

Yellowish brown (10YR5/4) medium sand, ranging from fine to coarse sand

Yellowish brown (10YR5/4) medium sand, grain size ranging from fine to coarse sand, loose

Pale brown (10YR6/3) medium sand, ranging from fine to coarse sand, discontinuous well cemented carbonate zones, numerous volcanic pebbles in top .1 foot

Pale brown (10YR6/3) medium sand, ranging from fine to coarse sand, moderately carbonate cemented, coarser than above, silicmetamorphic shist pebble

Dark brown to brown (7.5YR4/2) gravelly coarse sand, manganese stained calcite cement sandstone,

strongly cemented, strong reaction to $\mathrm{HCl}$, clasts are quartzite, granite, volcanics

Brown (7.5YR5/4) silty fine sand, poorly sorted, pinkish gray (7.5YR6/2) strongly carbonate cemented, strong reaction to $\mathrm{HCl}$

Brown (7.5YR5/4) silty fine sand, poorly sorted, ranging from fine to coarse sand, laminated, cross-laminated, very compact to strongly cemented carbonate zones

Dark yellowish brown (10YR4/4) fine sand, 2.5-2.0 phi mode, ranging from fine to coarse sand

Dark yellowish brown (10YR4/4) medium sand, ranging from fine to coarse sand, weakly carbonate cemented, soft carbonate nodules

Dark yellowish brown (10YR4/4) medium sandstone, magnesium stained, discontinuous strongly carbonate cemented zones

Dark yellowish brown (10YR4/4) gravelly coarse sand, fine sand matrix, poorly sorted

Yellowish brown (10YR5/4) fine sand, ranging from fine to medium sand, broken pebbles, washed out zone

Pink (7.5YR7/4) fine sandy silt, complete strong carbonate cementation

Brown (7.5YR5/2) silty fine sand, poorly sorted

Light brown (7.5YR6/4) fine sand, 3.0-2.5 phi mode, yellowish red (5YR5/6) red mottles, moderately carbonate cemented zone

Light brown (7.5YR6/4) silty fine sand, poorly sorted, grain size ranging from fine to medium sand Light brown (7.5YR6/4) silty fine sand, poorly sorted, grain size ranging from fine to medium sand Brown (10YR5/3) silty fine sand, poorly sorted, 2.0-1.5 phi mode, ranging from fine to medium sand Pink (7.5YR7/4) silty fine sand, poorly sorted, 2.0-1.5 phi mode, ranging from fine to medium sand, moderately carbonate cement zone

Pink (7.5YR7/4) sandstone, strongly cemented, washed, fragments

Brown (10YR5/3) coarse sand, moderately sorted, moderately carbonate cemented zone, thin red clay layer Pale brown (10YR6/3) silty fine sand, poorly sorted, cross-laminated, heavy minerals

Pale brown (10YR6/3) medium sand, ranging from fine to coarse sand, weakly laminated

medium sandstone, grain size ranging from medium to coarse, well cemented, strong manganese staining wad

Yellowish brown (10YR5/4) medium sand, ranging from fine to coarse sand, weakly laminated 
1044.31044 .5 1044.51045 .0

$1045.0 \quad 1046.7$

1046.71047 .0 1052.01052 .8

1052.81053 .0

$1053.0 \quad 1053.3$

1053.31055 .1

$1055.1 \quad 1055.8$

$1055.8 \quad 1058.9$

1062.01064 .3

$1064.3 \quad 1064.5$

$1064.5 \quad 1064.8$ $1064.8 \quad 1065.6$ $1065.6 \quad 1066.1$ $1072.0 \quad 1072.1$

$1072.1 \quad 1072.2$

1072.21072 .4

$1076.1 \quad 1076.7$

$1076.7 \quad 1077.3$

$1077.3 \quad 1078.9$

1078.91079 .0

$1079.0 \quad 1079.4$

$\begin{array}{lll}1082.0 & 1083.1\end{array}$

$1083.1 \quad 1083.7$

$1083.7 \quad 1083.8$ $1083.8 \quad 1084.1$ $1084.1 \quad 1084.7$

$1084.7 \quad 1084.8$ $1096.3 \quad 1096.4$ $1096.4 \quad 1096.7$ 1096.71097 .6 1097.61098 .4 1098.41098 .5

$1098.5 \quad 1098.7$ $1102.0 \quad 1102.6$

$1102.6 \quad 1102.8$

1112.01112 .3

$1112.3 \quad 1112.6$

1112.61113 .1

1113.11113 .2

1113.21113 .6

$1115.6 \quad 1116.5$

1116.51119 .6

1119.61119 .6

$1119.6 \quad 1120.1$
Light yellowish brown (10YR6/4) clayey silty fine sand, poorly sorted, massive, weakly cemented

Light yellowish brown (10YR6/4) fine sand, ranging from fine to coarse sand, indistinctly laminated, basal moderate carbonate cementation

Light yellowish brown (10YR6/4) silty fine sand, poorly sorted

Light yellowish brown (10YR6/4) clayey silty very fine sand, poorly sorted, massive, weakly cemented

Light yellowish brown (10YR6/4) silty clayey fine sand, 3.0-2.5 phi mode, poorly sorted, massive, weakly cemented

Brown (7.5YR5/4) silty clay

Light brown (7.5YR6/4) silty clayey fine sand

Light yellowish brown (10YR6/4) fine sand, 2.5-2.0 phi mode

Light yellowish brown (10YR6/4) fine sand, 2.5-2.0 phi mode, moderately carbonate cemented

Light yellowish brown (10YR6/4) fine sand, 2.5-2.0 phi mode

Yellowish brown (10YR5/4) medium sand, 2.5-1.5 phi mode, ranging from fine to coarse sand, scattered soft carbonate nodules

Yellowish brown (10YR5/4) medium sand, 2.5-1.5 phi mode, ranging from fine to coarse sand, weakly

carbonate cemented, scattered soft carbonate nodules

Yellowish brown (10YR5/4) silty clayey fine sand, 2.0-1.5 phi mode

Brown (10YR5/3) silty sand, $2.0-1.5$ phi mode, heavy mineral laminations

Brown (10YR5/3) silty fine sand, poorly sorted, 2.5-2.0 phi mode

Pink (5YR8/3-4) silty clay, moderately cemented carbonate zone, ash or old clay (?)

Reddish brown (5YR5/4) clay, indistinctly laminated, transition zone

Yellowish brown (10YR5/4) sandy clayey silt

Pale brown (10YR6/3) silty fine sand, poorly sorted, 2.5-1.5 phi mode, ranging from fine to coarse sand

Pale brown (10YR6/3) silty clayey fine sand, sand grain size ranging from fine to medium, poorly sorted, massive, weakly cemented

Yellowish brown (10YR5/4) coarse sand, 1.5-1.0 phi mode, ranging from medium to coarse sand, wet moisture condition, coarsens at base

Yellowish brown (10YR5/4) gravelly coarse sand, moderately sorted, loose, 1.5-1.0 phi mode, granules, small pebbles

Yellowish brown (10YR5/4) coarse sand, 1.5-1.0 phi mode, ranging from fine to coarse sand, wet moisture condition

Yellowish brown (10YR5/4) silty fine sand, poorly sorted, 2.5-2.0 phi mode

Yellowish brown (10YR5/4) medium sand, ranging from fine to coarse sand, strongly carbonate cemented, strong reaction to $\mathrm{HCl}$

Brown (10YR5/3) gravelly coarse sand, moderately sorted, loose

Yellowish brown (10YR5/4) medium sand, ranging from fine to coarse sand, fining down unit

Yellowish brown (10YR5/4) silty medium sand, 2.0-1.5 phi mode, poorly sorted, massive, weakly cemented

Gravel, broken subrounded pebbles of basalt and volcanics

Grayish brown (10YR5/2) silty medium sand, moderately carbonate cementation

Grayish brown (10YR5/2) silty medium sand

Grayish brown (10YR5/2) medium sand, 2.0-1.0 phi mode

Grayish brown (10YR5/2) coarse sand, moderately sorted, loose, 1.0-0.5 phi mode

Grayish brown (10YR5/2) silty clayey fine sand, 3.0-2.5 phi mode, poorly sorted, massive, weakly cemented

Light brownish gray (10YR6/2) to grayish brown (2.5Y5/2) silty clayey medium sand, 2.0-1.5 phi mode

Light brownish gray (10YR6/2) medium sand, 2.0-1.5 phi mode, ranging from fine to coarse sand,

laminated dark sand

Light brownish gray (10YR6/2) fine sand, 2.5-2.0 phi mode, laminated

Pale brown (10YR6/3) medium sand, 2.0-1.5 phi mode, flat laminated, heavy minerals

Pebble gravel, washed zone, basalt pebbles, carbonate cemented sand fragment

Brown (10YR5/3) fine sand, 2.5-2.0 phi mode, indistinctly laminated

Brown (10YR5/3) fine sand, 2.5-2.0 phi mode, indistinctly laminated, discontinuous moderately carbonate cementation

Brown (10YR5/3) fine sand, 2.5-2.0 phi mode, indistinctly laminated

Very pale brown (10YR7/3) fine sand, 2.5-2.0 phi mode

Gray (10YR5/1) medium sand, 2.0-1.5 phi mode, ranging from fine to coarse sand, laminated, scattered nodules,

Gray (10YR5/1) fine sand, 3.0-2.5 phi mode

Gray (10YR5/1) fine sand, 3.0-2.5 phi mode, weakly cemented 
$1120.1 \quad 1120.3$

$1122.0 \quad 1122.7$

$1122.7 \quad 1122.8$

$1122.8 \quad 1122.9$

1122.91125 .7

1125.71125 .8

$1125.8 \quad 1125.9$ 1132.01132 .9

1132.91133 .5

1133.51134 .5

1142.01142 .1

$1142.1 \quad 1142.3$

1162.01162 .8

$1170.2 \quad 1170.4$

1170.41171 .5

1171.51171 .7

1181.01181 .4

1181.41181 .5

1181.51183 .3

1183.31183 .9

1183.91184 .5

$1184.5 \quad 1184.7$

$1184.7 \quad 1185.4$

1189.01193 .3

1195.21196 .5

1196.51196 .8

1196.81197 .0

1203.01209 .9

1209.91212 .2

1213.01213 .8

1213.81214 .0

1214.01215 .9

1215.91217 .0

$1222.0 \quad 1223.0$

1223.01223 .2

$1223.6 \quad 1224.1$

$1224.1 \quad 1225.0$

$1225.0 \quad 1226.4$

1226.41226 .4

1226.41226 .5

1226.51227 .4

1233.21241 .7

1242.21242 .8

$1242.8 \quad 1243.3$
Gray (10YR5/1) fine sand, 3.0-2.5 phi mode

Pale brown (10YR6/3) silty fine sand, poorly sorted, 3.0-2.0 phi mode, ranging from fine to medium sand Pale brown (10YR6/3) silty fine sand, poorly sorted, 3.0-2.0 phi mode, ranging from fine to medium sand, light gray (10YR7/2) moderately carbonate-cemented zone

Pale brown (10YR6/3) silty fine sand, poorly sorted, 3.0-2.0 phi mode, ranging from fine to medium sand Pale brown (10YR6/3) silty fine sand, poorly sorted, 2.5-2.0 phi mode, sand ranging from fine to coarse, soft carbonate nodules

Pale brown (10YR6/3) silty fine sand, poorly sorted, 2.5-2.0 phi mode, ranging from fine to coarse sand, soft carbonate nodules, strongly cemented

Pale brown (10YR6/3) silty fine sand, poorly sorted, 3.0-2.5 phi mode

Brown (10YR5/3) silty fine sand, poorly sorted, 3.0-2.5 phi mode, ripple laminated, moderately cemented, heavy minerals

Brown (10YR5/3) medium sand, 2.0-1.5 phi mode, moderately cemented

Brown (10YR5/3) medium sand, ranging from fine to coarse sand, moderately cemented, basal soft

carbonate nodules

Brown (10YR5/3) fine sand, ranging from fine to medium sand, moderately cemented

Brown (10YR5/3) fine to medium sand

Light brownish gray (10YR6/2) and pale brown (10YR6/3) medium to fine sand, 2.5-2.0 phi mode

Very pale brown (10YR7/3) fine sandstone, strongly cemented, strong reaction to $\mathrm{HCl}$

Brown (10YR5/3) to pale brown (10YR6/3) medium sand, 2.5-1.5 phi mode

Brown (10YR5/3) gravelly coarse sand, 2.0-1.0 phi mode, pebbles, granite, quartzite, volcanics

Light gray (5Y7/1) fine sandy silt, laminated

Dark grayish brown (10YR4/2) clayey sandy silt

Light brownish gray (10YR6/2) gravelly coarse sand, 1.5-1.0 phi mode, ranging from fine to coarse sand matrix, poorly sorted, variegated, clasts of brown (10YR5/3) clay silt and silt, volcanic fragments, mica fragments, clay ripup clasts, altered volcanics

Light brownish gray (10YR6/2) silty fine sand, poorly sorted, ranging from fine to coarse sand, volcanics, variegated clasts

Brown (10YR5/3) medium to fine sand, moderately sorted

Brown (10YR5/3) fine sand

Pale brown (10YR6/3) medium sand

Light brownish gray (10YR6/2) to pale brown (10YR6/3) medium sand, 2.0-1.5 phi mode, laminated

Pale brown (10YR6/3) medium sand, 1.5-2.5 phi mode, laminated

Pale brown (10YR6/3) medium sand, 1.5-2.5 phi mode, laminated, white (10YR8/2) soft carbonate nodules Pale brown (10YR6/3) medium sand, 1.5-2.5 phi mode, laminated

Yellowish brown (10YR5/4) medium sand, 2.0-1.5 phi mode, indistinctly laminated, large carbonate nodule Yellowish brown (10YR5/4) medium sand, 2.0-1.5 phi mode, ranging from fine to coarse sand, massive

Pale brown (10YR6/3) medium sand, $2.0-3.0$ phi mode, weakly laminated, wet moisture condition

Pale brown (10YR6/3) medium sand, ranging from fine to coarse sand, moderately cemented, soft carbonate nodules, wet moisture condition

Pale brown (10YR6/3) medium sand, 2.0-3.0 phi mode, weakly laminated, weakly cemented, wet moisture condition

Light yellowish brown (10YR6/4) to yellowish brown (10YR5/4) medium sand, ranging from fine to coarse sand, laminated, layered, weakly cemented, numerous soft carbonate nodules

Yellowish brown (10YR5/4) medium sand, ranging from fine to coarse sand

Yellowish brown (10YR5/4) medium sand, ranging from fine to coarse sand, weakly basal carbonate cemented

Pale brown (10YR6/3) medium sand, ranging from fine to coarse sand, weakly carbonate cemented Yellowish brown (10YR5/4) medium sand, ranging from fine to coarse sand, few soft carbonate nodules Yellowish brown (10YR5/4) medium sand, ranging from fine to coarse sand

Yellowish brown (10YR5/4) medium sand, ranging from fine to coarse sand, thin moderately carbonate cemented layer

Yellowish brown (10YR5/4) medium sand, ranging from fine to coarse sand

Light yellowish brown (10YR6/4) medium sand

Yellowish brown (10YR5/4) medium sand, grain size ranging from fine to coarse sand, clean, massive, carbonate nodules, wet moisture condition

Yellowish brown (10YR5/4) medium sand. Ranging from fine to coarse sand, discontinuous carbonate zone, very compact, weakly cemented

Yellowish brown (10YR5/4) medium sand, ranging from fine to coarse sand, very compact, weakly cemented 
$1244.0 \quad 1245.2$

$1245.2 \quad 1245.6$

$1245.6 \quad 1246.2$

$1246.2 \quad 1246.6$

1246.61247 .6

$1254.0 \quad 1255.8$

$1255.8 \quad 1256.0$

$1256.0 \quad 1256.1$

$1259.5 \quad 1260.0$

1260.01260 .4

$1260.4 \quad 1260.5$

1260.51260 .7

$1260.7 \quad 1260.9$

1260.91261 .3

1261.31261 .8

$1261.8 \quad 1262.0$

$1262.0 \quad 1262.5$

$1262.5 \quad 1262.7$

1262.71266 .6

1266.61267 .0

$1267.0 \quad 1267.7$

1267.71267 .8

1267.81268 .0

$1268.0 \quad 1268.2$

1269.01269 .1

$1269.1 \quad 1269.7$

$1269.7 \quad 1272.6$

$1272.6 \quad 1272.7$

$1272.7 \quad 1272.9$

$1272.9 \quad 1273.2$

$1273.2 \quad 1273.3$

1273.31274 .6

$1274.6 \quad 1277.0$

$\begin{array}{lll}1277.0 & 1278.7\end{array}$

$1279.0 \quad 1279.2$

1279.21279 .2

$1279.2 \quad 1281.8$

$1281.8 \quad 1281.9$

$1281.9 \quad 1282.0$

$\begin{array}{lll}1282.0 & 1282.8\end{array}$

$1282.8 \quad 1283.3$

$1283.3 \quad 1284.9$

$1289.0 \quad 1289.2$

$1289.2 \quad 1289.4$

$1289.4 \quad 1290.0$

$\begin{array}{lll}1290.0 & 1290.2\end{array}$

$1290.2 \quad 1290.4$
Light yellowish brown (10YR6/4) medium sand, ranging from fine to coarse sand, white carbonate cement Yellowish brown (10YR5/4) medium sand, ranging from fine to coarse sand, loose

Dark yellowish brown (10YR4/4) to reddish brown (5YR4/4) silty clay, irregular pockets of fine sand

Reddish brown (5YR4/4) silty clay

Brown (10YR5/3) clayey sandy silt

Yellowish brown (10YR5/4) medium sand, 2.0-1.5 phi mode, ranging from fine to coarse sand, laminated, gravelly, poorly sorted

Brown (10YR5/3) silty fine sand, poorly sorted, massive

Brown (10YR5/3) silty fine sand, poorly sorted, discontinuously weakly carbonate cemented

White (10YR8/1) medium sand, moderately cemented carbonate zone

Light brownish gray (10YR6/2) medium sand, 2.5-1.5 phi mode, moderately sorted

Light brownish gray (10YR6/2) gravelly coarse sand, moderately sorted, loose

Yellowish brown (10YR5/4) medium sand, moderately discontinuous cementation

Yellowish brown (10YR5/4) silt, microlaminated, very compact to strongly cemented

Pink (7.5YR7/4) fine sand, 2.5-2.0 phi mode, laminated, discontinuously moderately cemented lenses,

heavy minerals

Brown (10YR5/3) silt, microlamination, thin sections of very fine sand, discontinuously moderately

cemented, scattered soft carbonate nodules

Brown (10YR5/3) silty fine sand, poorly sorted, 2.0-3.0 phi mode, laminated

Brown (10YR5/3) silt and clayey silt, microlaminated

Light brownish gray (10YR6/2) fine sand, irregularly discontinuously moderate carbonate cementation, heavy minerals

Brown (10YR5/3) medium sand, 2.5-1.5 phi mode, moderately sorted, laminated, heavy minerals, weak carbonate cemented zone, discontinuous, iron manganese staining

Brown (10YR5/3) medium sand, 2.5-1.5 phi mode, moderately sorted, laminated, heavy minerals, well cemented carbonate zone, discontinuous, iron manganese staining

Brown (10YR5/3) medium sand, 2.5-2.0 phi mode, ranging from fine to coarse sand

Yellowish brown (10YR5/4) fine sand, 3.0-2.0 phi mode, ranging from fine to medium sand, weakly cemented

Yellowish brown (10YR5/4) medium sandstone, strongly cemented, strong reaction to $\mathrm{HCl}$, iron manganese stain

Yellowish brown (10YR5/4) medium sand, 3.0-2.0 phi mode, weakly cemented

Light gray (10YR7/2) medium sand, 2.5-1.5 phi mode, moderately cemented

Reddish brown (5YR4/4) silty fine sand, poorly sorted, 2.5-1.5 phi mode, ranging from fine to medium sand, red clay clasts

Grayish brown (10YR5/2) medium sand, 2.5-1.5 phi mode, laminated, moderately sorted, compact, heavy minerals

Light brownish gray (10YR6/2) fine sand, 3.0-2.5 phi mode, continuously moderately carbonate cemented

Light brownish gray (10YR6/2) fine sand, 3.0-2.5 phi mode

Light gray (10YR7/2) silt, strongly cemented, strong reaction to $\mathrm{HCl}$

Pale brown (10YR6/2) silty fine sand, poorly sorted, laminated

Pale brown (10YR6/2) silty fine sand, poorly sorted, laminated, moderately carbonate cemented

Pale brown (10YR6/2) silty fine sand, poorly sorted, laminated

Pale brown (10YR6/2) silty fine sand, poorly sorted, laminated, strong continuous carbonate cemented

zone

Brown (7.5YR5/4) silty clay

Yellowish brown (10YR5/4) silty clayey fine sand, poorly sorted, massive, weakly cemented

Pinkish gray (10YR6/2) medium sand, 2.5-1.5 phi mode, poorly sorted, slightly silty

Yellowish brown (10YR5/4) fine sand, 3.0-2.5 phi mode, thin weakly cemented carbonate zone

Yellowish brown (10YR5/4) fine sand

Yellowish brown (10YR5/4) fine sand, 3.0-2.5 phi mode, weakly cemented carbonate zone

White (10YR8/2) fine sand, strongly cemented carbonate zone

Brown (10YR5/3) silt and yellowish brown (10YR5/4) medium sand, 2.0-1.0 phi mode, clasts of pebble silt, clay ripup clasts

Light brownish gray (10YR6/2) medium sand, 2.0-1.0 phi mode, ranging from fine to coarse sand, clay ripup intraclasts

Pale brown (10YR6/3) fine sand, 2.5-2.0 phi mode, ranging from fine to coarse sand

Pale brown (10YR6/3) medium sand, ranging from fine to coarse sand, laminated, pebbles

Pale brown (10YR6/3) fine sand, 3.0-2.5 phi mode, some silt

Brown (10YR5/3) fine sand, 2.5-2.0 phi mode, ranging from fine to coarse sand 
1290.41290 .5

$1299.0 \quad 1300.0$

$1300.0 \quad 1300.1$

1300.11300 .3

$1300.3 \quad 1300.7$

1305.41305 .8

1305.81306 .1

1306.11308 .4

$1308.4 \quad 1308.5$

1395.91397 .8

$1397.8 \quad 1398.0$

$1398.0 \quad 1398.2$

$1398.2 \quad 1398.6$

1398.61398 .7

1398.71399 .6

$1399.6 \quad 1399.7$

1399.71401 .8

$1401.8 \quad 1402.0$

$1402.0 \quad 1403.1$

$1403.1 \quad 1403.3$

$1403.3 \quad 1404.4$

$1405.0 \quad 1406.5$

$1406.5 \quad 1411.5$

$1411.5 \quad 1412.1$

$1412.1 \quad 1414.7$

$1414.7 \quad 1414.9$

1414.91415 .0

$1415.0 \quad 1416.7$

$1422.0 \quad 1422.6$

$1422.6 \quad 1422.7$

$1422.7 \quad 1422.9$

1422.91423 .9

1423.91425 .9

$1432.0 \quad 1434.8$

$1434.8 \quad 1435.0$

$1435.0 \quad 1436.4$

$1436.4 \quad 1437.2$

$1437.2 \quad 1437.4$

1437.41437 .9

1437.91438 .9

$1438.9 \quad 1439.8$

$1439.8 \quad 1440.2$
Brown (10YR5/3) fine sand, weakly carbonate cemented

Yellowish brown (10YR5/4) medium sand, 2.5-1.5 phi mode, ranging from fine to coarse sand, granules

Reddish brown (5YR5/3) gravelly coarse sand, 2.0-1.5 phi mode, quartz, basalt pebbles

Reddish brown (5YR4/3) silty clayey sand, discontinuously moderate carbonate cementation

Reddish brown (5YR4/3) silty sand and silty clayey fine sand

Pinkish white (5YR8/2) fine sandstone, strong carbonate cementation

Brown (10YR5/3) medium sand, 2.5-2.0 phi mode, moderately sorted

Brownish yellow (10YR6/6) and grayish brown (10YR5/2) fine sand, 2.5-2.0 phi mode, ranging from fine to medium sand, some silt, moderately sorted, prominent carbonate zone with iron staining, irregular nodules throughout

Brownish yellow (10YR6/6) and grayish brown (10YR5/2) fine sand, 2.5-2.0 phi mode, ranging fine to coarse sand, some silt, poorly sorted, prominent carbonate zone with iron staining, irregular nodules throughout, continuous cementation

Light gray to gray (10YR6/1) fine sand, 3.0-2.5 phi mode, cross lamination, ripple lamination, heavy minerals, discontinuous carbonate cementation, clay clasts $.75-2 \mathrm{~cm}$ in length

Light gray to gray (10YR6/1) fine sand, 3.0-2.5 phi mode, ripple cross lamination, heavy minerals, clay clasts $0.75-2 \mathrm{~cm}$ in length

Light brownish gray (10YR6/2) silt, interbedded silt clay and fine sand

Light brownish gray (10YR6/2) siltstone, laminated, dense, strongly cemented, strong reaction to $\mathrm{HCl}$

Dark grayish brown (10YR4/2) fine sand, interlaminated silty clay and silt

Dark grayish brown (10YR4/2) siltstone and silty clay, laminated, very dense, strongly cemented, strong reaction to $\mathrm{HCl}$

Pale brown (10YR6/3) fine sand, 3.0-2.0 phi mode, cross laminated

Pale brown (10YR6/3) medium sand, 2.5-1.5 phi mode, crossbedded

Pale brown (10YR6/3) medium sand, 2.0-1.0 phi mode, flat laminated, interlaminated very fine sand and

fine sand (2.5-2.0 phi), locally cross-laminated

Light yellowish brown (10YR6/4) silty fine sand, poorly sorted, 3.0-2.0 phi mode, cross-laminated

Pale brown (10YR6/3) fine sand, 3.0-2.0 phi mode, cross-laminated

Pale brown (10YR6/3) fine sand, 3.0-2.0 phi mode, cross-laminated, discontinuously cemented

Brown (10YR5/3) medium sand, 2.5-1.0 phi mode, ranging from fine to coarse sand, interlaminated, lowest laminations contain possible pumice, clasts of green clayey silt

Gray (10YR5/1) medium sand, 2.0-1.5 phi mode, ranging from fine to coarse sand, granules and clasts of silt clay, small pebbles, small soft carbonate nodules

Gray (10YR5/1) fine sand, 2.5-2.0 phi mode, ranging from fine to medium sand

Gray (10YR5/1) fine sand, 2.5-2.0 phi mode, ranging from fine to medium sand, weakly discontinuously cemented

Gray (10YR5/1) medium sand, 2.5-2.0 phi mode, ranging from fine to coarse sand

Gray (10YR5/1) medium sandstone, 2.5-2.0 phi mode, grain size ranging from fine to medium, strongly

cemented, strong reaction to $\mathrm{HCl}$

Gray (10YR5/1) medium sand, 2.5-2.0 phi mode, ranging from fine to medium sand

Gray (10YR5/1) medium to fine sandstone pieces, strongly cemented, strong reaction to $\mathrm{HCl}$

Yellowish brown (1OYR5/4) fine sandstone, 2.5-2.0 phi mode, ranging from fine to medium sand, strongly carbonate cemented, strong reaction to $\mathrm{HCl}$

Yellowish brown (10YR5/4) medium sand, 2.5-1.5 phi mode

Yellowish brown (10YR5/4) medium sandstone, 2.5-1.5 phi mode, strongly carbonate cemented, strong reaction to $\mathrm{HCl}$ zone

Yellowish brown (10YR5/4) medium sand, 2.5-1.5 phi mode

Brown (10YR5/3) fine sand, 2.5-2.0 phi mode, ranging from fine to coarse sand, indistinctly laminated, heavy minerals

Grayish brown (10YR5/2) medium sand, 2.5-1.5 phi mode, laminated, cross-laminated, rippled, well sorted, heavy minerals

Dark grayish brown (10YR4/2) fine sand, 2.5-2.0 phi mode, ranging from fine to medium sand, laminated, cross-laminated, moderately sorted, heavy minerals

Grayish brown (10YR5/2) medium sand, 2.5-1.5 phi mode, mica fragments

Light brownish gray (10YR6/2) silty fine sand, poorly sorted, 2.5-2.0 phi mode, cross-laminated, heavy minerals

Light brownish gray (10YR6/2) siltstone, strongly cemented, strong reaction to $\mathrm{HCl}$

Grayish brown (10YR5/2) fine sand, 2.5-2.0 phi mode, ranging from fine to medium sand, flat laminated

Gray (10YR5/1) medium sand, 2.0-1.5 phi mode, cross-laminated, clay nodules

Light brownish gray (10YR6/2) medium sand, 2.5-1.5 phi mode, ranging from fine to medium sand 
Grayish brown (10YR5/2) fine sand, 2.5-2.0 phi mode, ranging from fine to coarse sand, cross-laminated, heavy minerals

1440.61440 .9

1440.91442 .0

1442.01442 .5

1442.51442 .8

1442.81444 .2

1444.21445 .5

1445.51446 .5

1446.51447 .1

$1447.1 \quad 1448.2$

$1448.2 \quad 1449.4$

1449.41449 .9

1449.91451 .4

$1452.0 \quad 1452.4$

$1452.4 \quad 1452.7$

$1460.8 \quad 1462.0$

$1462.0 \quad 1462.1$

$1462.1 \quad 1462.3$

$1462.3 \quad 1462.4$

1462.41462 .5

$1462.5 \quad 1463.0$

1463.01463 .2

1463.21464 .0

$1464.0 \quad 1466.5$

1466.51467 .9

$1472.0 \quad 1472.5$

$1472.5 \quad 1473.4$

1473.41474 .7

$1474.7 \quad 1477.0$

$1477.0 \quad 1477.8$

$1477.8 \quad 1478.3$

$\begin{array}{lll}1482.0 \quad 1482.2 & \end{array}$

1482.21483 .0

1483.01483 .1

$1483.1 \quad 1483.7$

$1483.7 \quad 1483.9$

1483.91484 .8

$1484.8 \quad 1485.4$

1485.41486 .0

1486.01486 .3

1486.31486 .6
Light brownish gray (10YR6/2) medium sand, 2.5-1.5 phi mode, ranging from fine to coarse sand

Dark grayish brown (10YR4/2) fine sand, $2.5-2.0$ phi mode, ranging from fine to coarse sand

Grayish brown (10YR5/2) medium sand, 2.0-1.5 phi mode, cross-laminated, flat laminated, heavy minerals Grayish brown (10YR5/2) medium sand, 2.0-1.5 phi mode, ranging from fine to coarse sand, slightly

laminated

Grayish brown (10YR5/2) fine sand, 2.5-2.0 phi mode, ranging from fine to coarse sand, weakly cemented, strong reaction to $\mathrm{HCl}$,carbonate zone

Brown (10YR5/3) medium sand, 2.0-1.5 phi mode, ranging from fine to very coarse sand few scattered silt clay clasts, iron and clay cemented, strong reaction to $\mathrm{HCl}$ zone

Dark grayish brown (10YR4/2) fine sand, 2.5-2.0 phi mode, ranging from fine to coarse sand, laminated, scattered carbonate lenses, heavy minerals with manganese stain association

Dark grayish brown (10YR4/2) fine sand, 3.0-2.0 phi mode, ranging from fine to coarse sand

Brown (10YR5/3) fine sand, 3.0-2.5 phi mode, irregular soft carbonate nodules

Grayish brown (10YR5/2) fine sand, 3.0-2.0 phi mode, ranging from fine to coarse sand, laminated

Dark grayish brown (10YR4/2) medium sand, 1.0-2.0 phi mode, thinly bedded to laminated, clasts of clay andsilt

Dark gray (10YR4/1) fine sand, 3.0-2.0 phi mode, ranging from fine to coarse sand, cross-laminated, heavy minerals

Dark grayish brown (10YR4/2) fine sand, $2.5-2.0$ phi mode, ranging from fine to medium sand, laminated heavy minerals

Gray to grayish brown (10YR5/1-2) medium sand, 1.0-2.0 phi mode, ranging from fine to coarse sand and granules

Gray to grayish brown (10YR5/1-2) medium sand, 1.0-2.0 phi mode, ranging from fine to coarse sand and granules, white moderate carbonate cementation

Reddish brown (5YR4/3) slightly silty "Hershey clay", pockets and stringers of fine sand

Brown (10YR5/3) coarse sand, moderately sorted, loose, scattered granules

Yellowish brown (10YR5/4) silty fine sand, poorly sorted, sand ranging from fine to medium

Yellowish brown (10YR5/4) coarse sand, moderately sorted, loose, green clasts

Yellowish brown (10YR5/4) medium sand, ranging from fine to coarse sand

Yellowish brown (10YR5/4) fine sandstone, manganese stained, strongly carbonate cemented, strong reaction to $\mathrm{HCl}$

Yellowish brown (10YR5/4) silty fine sand, poorly sorted, massive, weakly cemented, strong reaction to $\mathrm{HCl}$

Manganese stained medium sandstone, strongly carbonate cemented, strong reaction to $\mathrm{HCl}$

Gray (10YR5/1) coarse sand, moderately sorted, loose, variegated grains of pink feldspar, pink, red, and purple volcanic rock fragments

Gray (10YR5/1) coarse sand, scattered granules, laminations, very dark gray (10YR3/1) concentrated heavy minerals, variegated grains of pink feldspar, pink, red, and purple volcanic rock fragments

Pale brown (10YR6/3) medium sand, ranging from fine to coarse sand and granules

Brown (10YR5/3) medium sand, 2.5-1.5 phi mode, laminated, heavy minerals

Yellowish brown (10YR5/4) fine sand, 3.0-2.0 phi mode, ranging from fine to coarse sand, cross-bedded,

ripple laminated, heavy mineral lamination, carbonate cement zones

Brown to dark brown (10YR4/3) medium sand, 2.0-1.5 phi mode, laminated

Yellowish brown (10YR5/4) medium sand, 1.5-3.0 phi mode, ranging from fine to coarse sand, laminated, poorly sorted

White (10YR8/1) fine sandstone, strongly carbonate cemented, strong reaction to $\mathrm{HCl}$

Dark brown to brown (10YR4/3) fine sand, 2.5-2.0 phi mode, ranging from fine to coarse sand, laminated, weakly carbonate cemented, strong reaction to $\mathrm{HCl}$, heavy minerals

Brown (10YR5/3) fine sand, 2.5-2.0 phi mode, ranging from fine to coarse sand, laminated

Very pale brown (10YR7/3) medium sandstone, 1.5-2.5 phi mode, strongly carbonate cemented, strong reaction to $\mathrm{HCl}$

Dark brown to brown (10YR4/3) silty very fine sand, 3.0-2.5 phi mode, laminated, heavy minerals

Very pale brown (10YR7/3) medium sandstone, ranging from fine to medium sand grain size, strongly

carbonate cemented, strong reaction to $\mathrm{HCl}$

Yellowish brown (10YR5/4) fine sand, 2.5-2.0 phi mode, ranging from fine to coarse sand, massive

Yellowish brown (10YR5/4) silty very fine sand, laminated, cross-bedded

Light brownish gray (10YR6/2) silt, laminated, cross-bedded, heavy minerals

Dark brown to brown (10YR4/3) silty very fine sand, $2.5-2.0$ phi mode, laminated, heavy minerals 
$1486.6 \quad 1487.8$

1487.81488 .2

$1492.0 \quad 1492.3$

1492.31492 .4

$1492.4 \quad 1492.8$

$1492.8 \quad 1493.7$

1493.71493 .9

1493.91494 .0

$1494.0 \quad 1494.3$

1494.31494 .7

1494.71495 .7

1495.71496 .3

1496.31496 .4
Light brownish gray (10YR6/2) silt, laminated, cross-bedded, heavy minerals Dark brown to brown (10YR4/3) silty very fine sand, 2.5-2.0 phi mode, laminated, heavy minerals Light gray (10YR7/2) medium sandstone, ranging from fine to coarse sand grains, strongly carbonate cemented, strong reaction to $\mathrm{HCl}$

Reddish brown (5YR4/4) clay, laminations, heavy mineral layers

Brown (10YR5/3) silty clayey fine sand, 3.0-2.5 phi mode, clay lamination

Brown (10YR5/3) fine sand, 2.0-3.0 phi mode, ranging from fine to medium sand, laminations of silt, few carbonate nodules

Brown (10YR5/3) medium sand, 1.0-2.0 phi mode, ranging from fine to coarse sand, massive Brown (10YR5/3) very fine sand, 3.0-2.0 phi mode, laminated

Dark brown to brown (10YR4/3) medium sand, 1.0-2.0 phi mode, ranging from fine to coarse sand, red clay clasts

Light brown (7.5YR6/4) silty fine sand, poorly sorted , 2.5-2.0 phi mode, ranging from fine to medium sand, clay clasts

Grayish brown (10YR5/2) silty clayey fine sand, ranging from fine to medium sand grains, laminations, heavy minerals, clay ripup clasts

Dark brown to brown (10YR4/3) fine sand, 2.0-3.0 phi mode, ranging from fine to medium sand Brown (10YR5/3) silt and silty clay, interbedded, very compact brown (10YR5/3) very fine sandstone, strongly carbonate cemented, strong reaction to $\mathrm{HCl}$, strong reaction to $\mathrm{HCl}$, fining up unit 


\section{APPENDIX B}

\section{DETAILED GEOPHYSICAL LOGS FOR THE 98TH STREET CORE HOLE}

Natural gamma, caliper, spontaneous potential, conductivity, short and long resistivity, and tension 
Geophysical logs for 98 th Street core hole:

APPENDIX B.

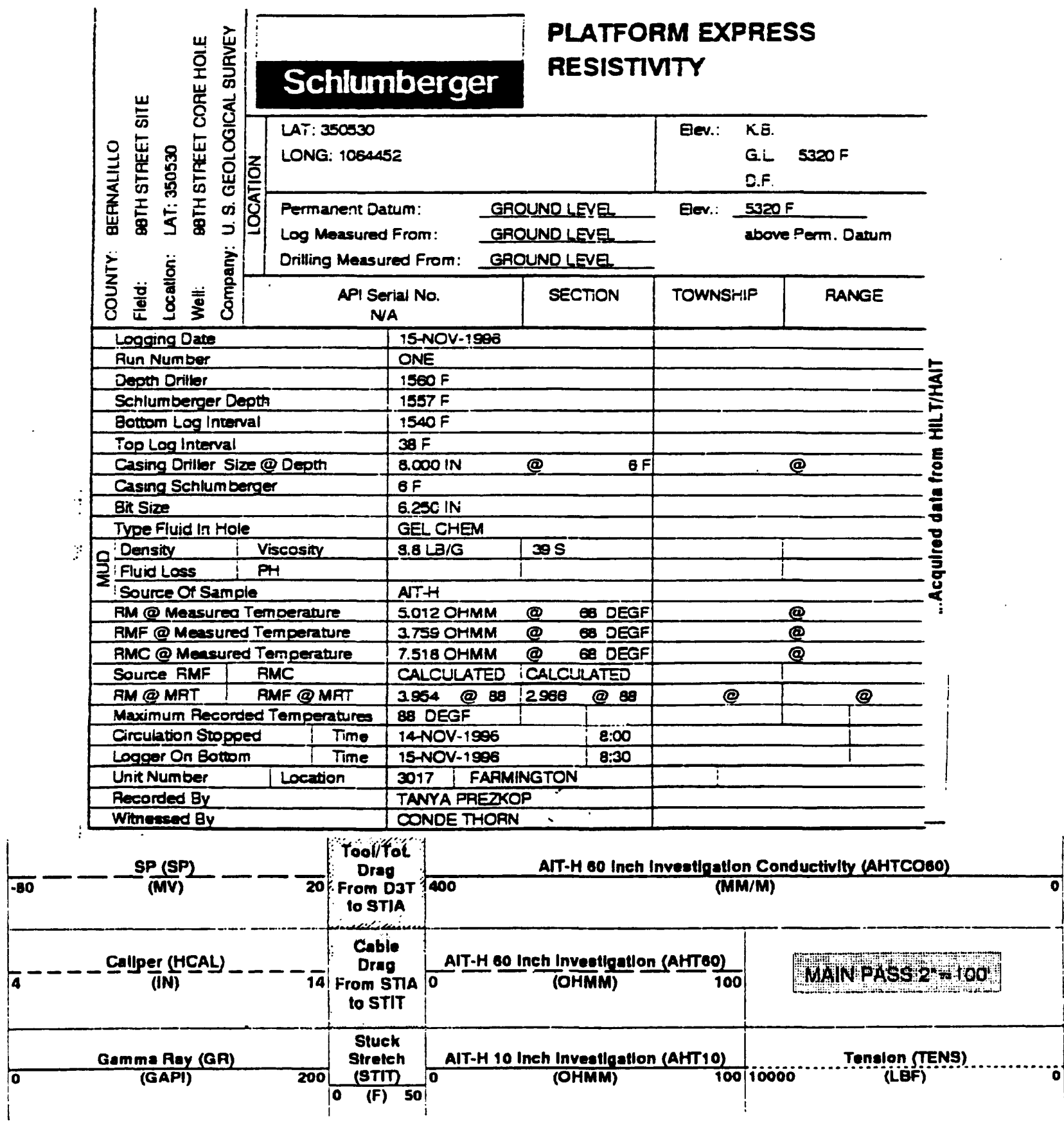




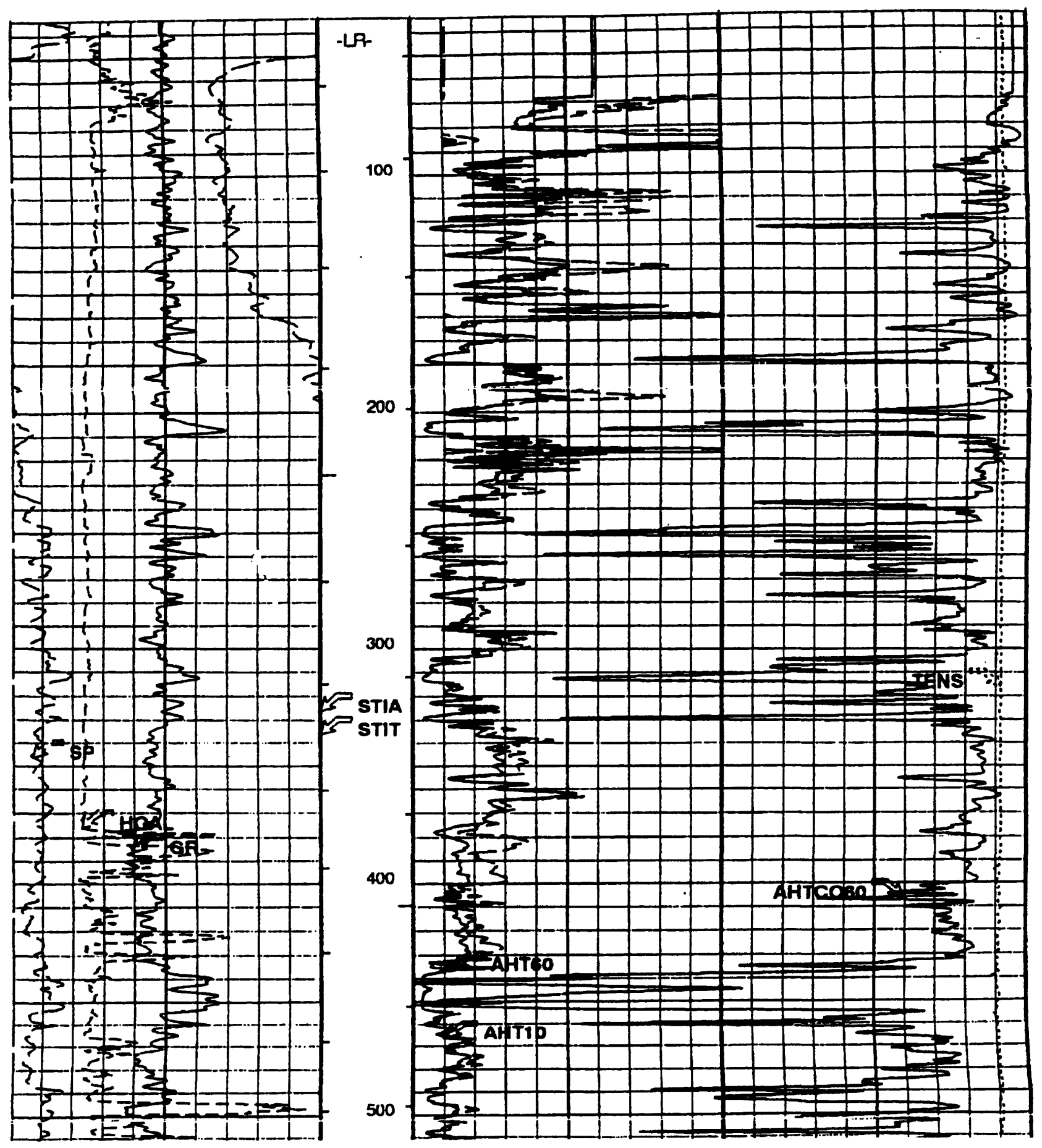




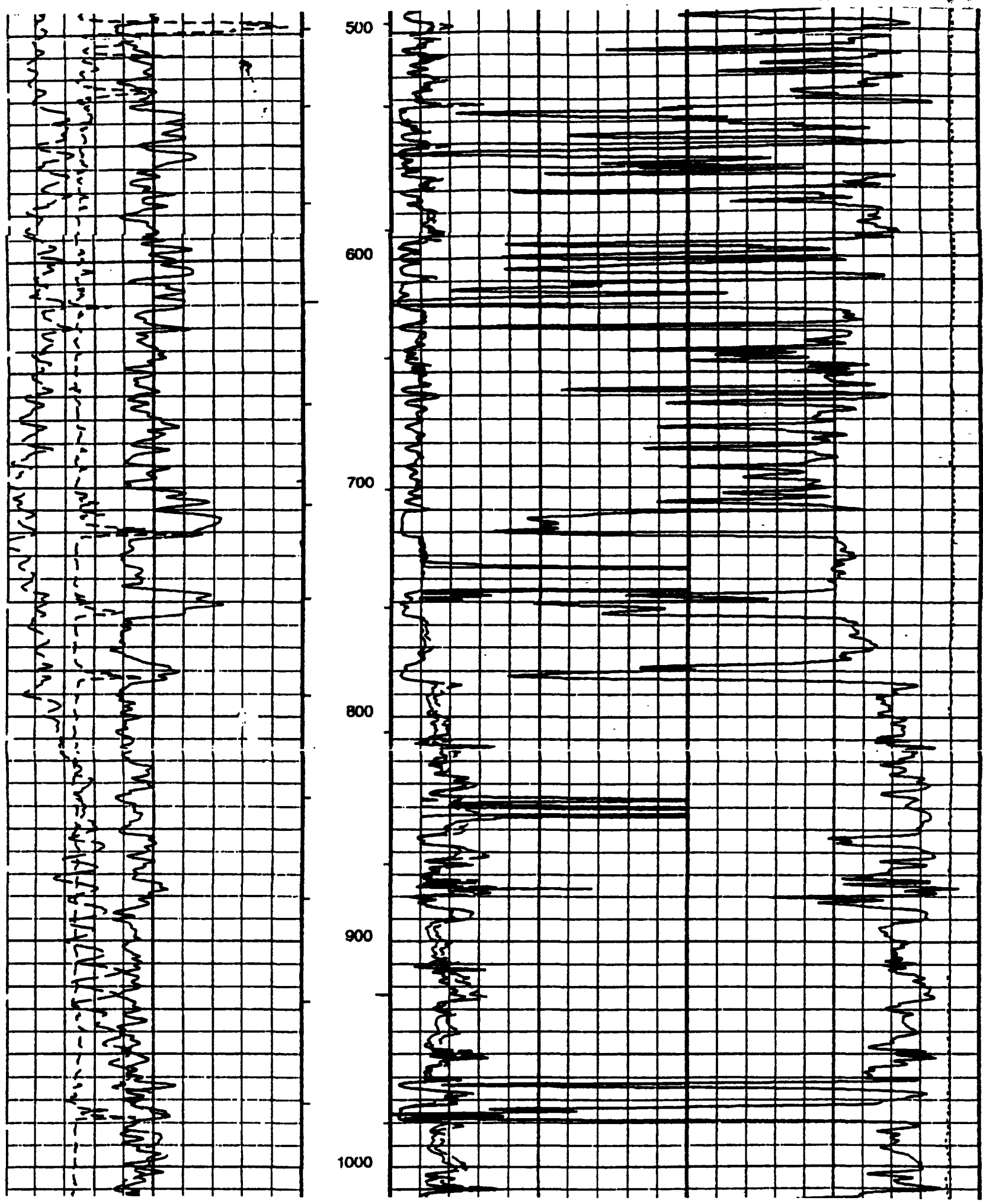




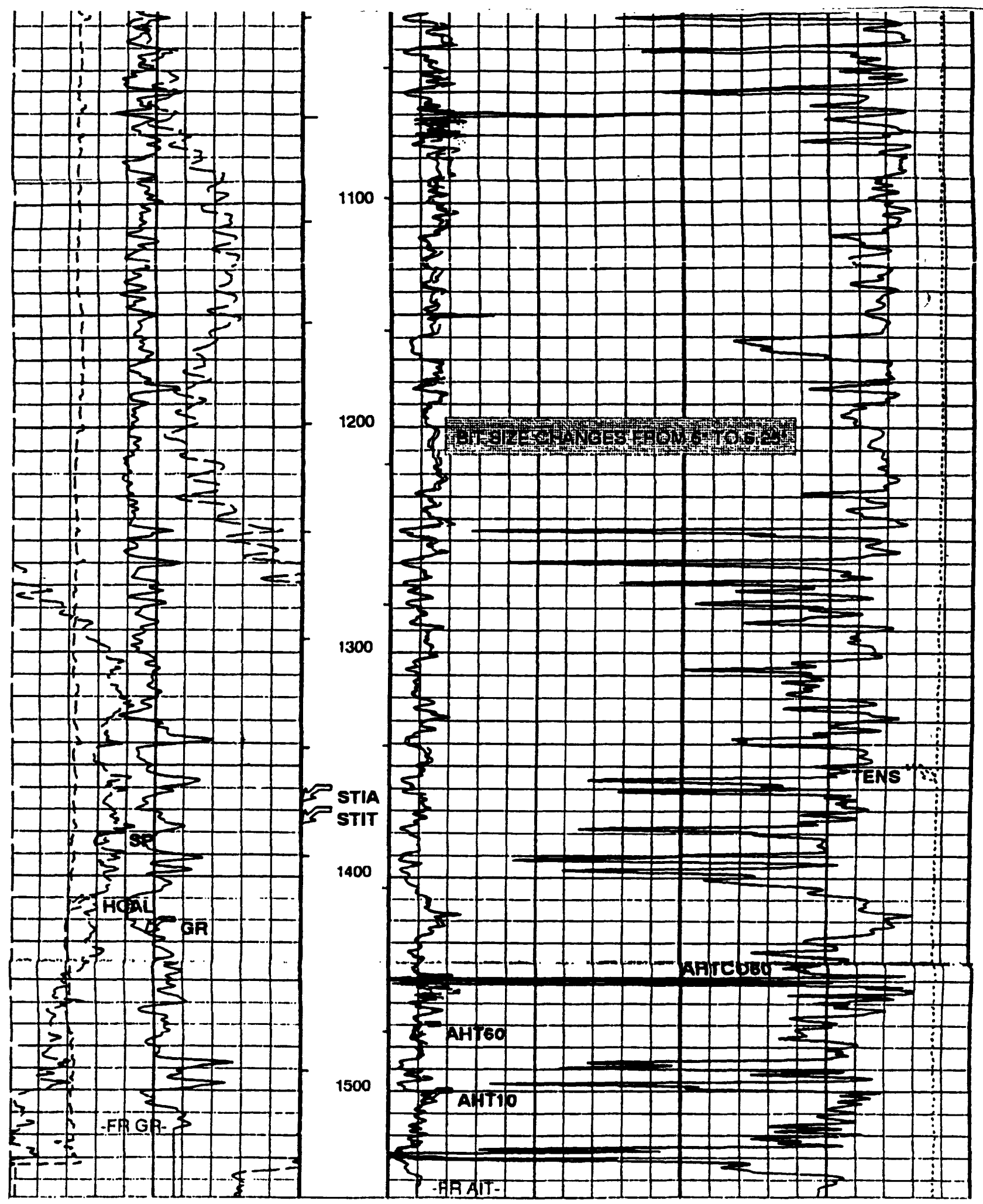




\section{APPENDIX C}

\section{DETAILED GEOPHYSICAL LOGS FOR THE 98TH STREET CORE HOLE}

Natural gamma, caliper, formation density, and photoelectric absorption 


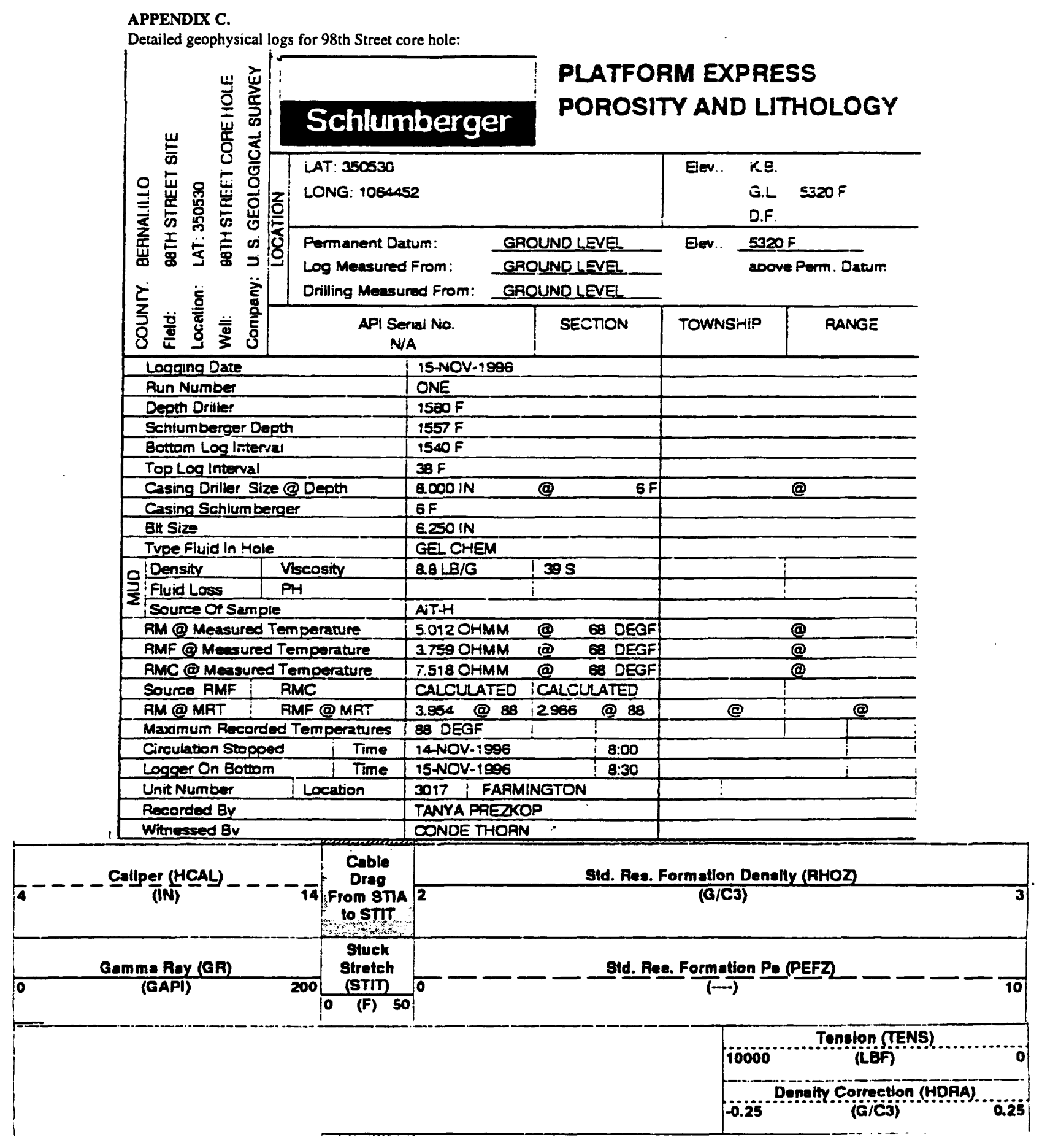




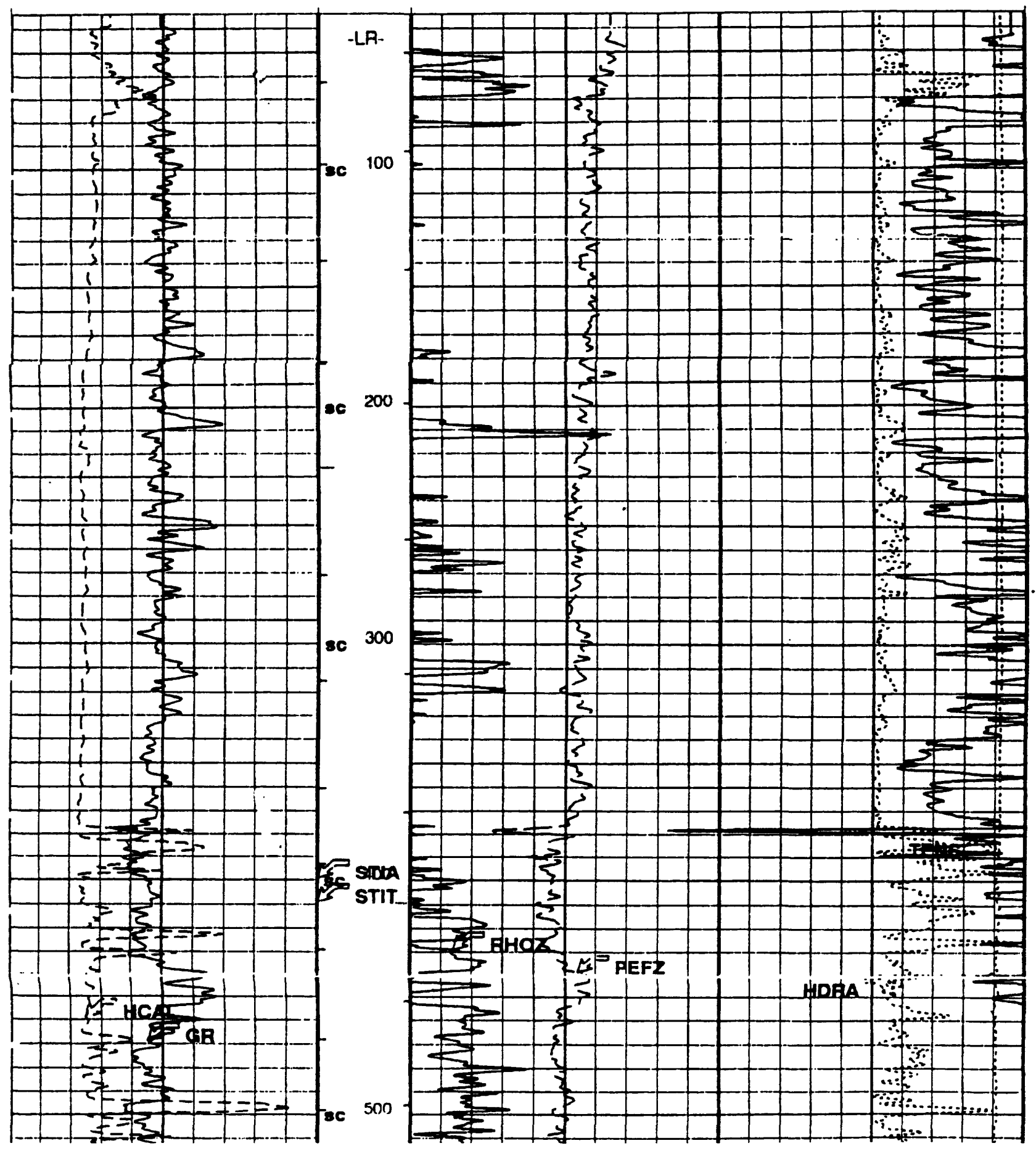




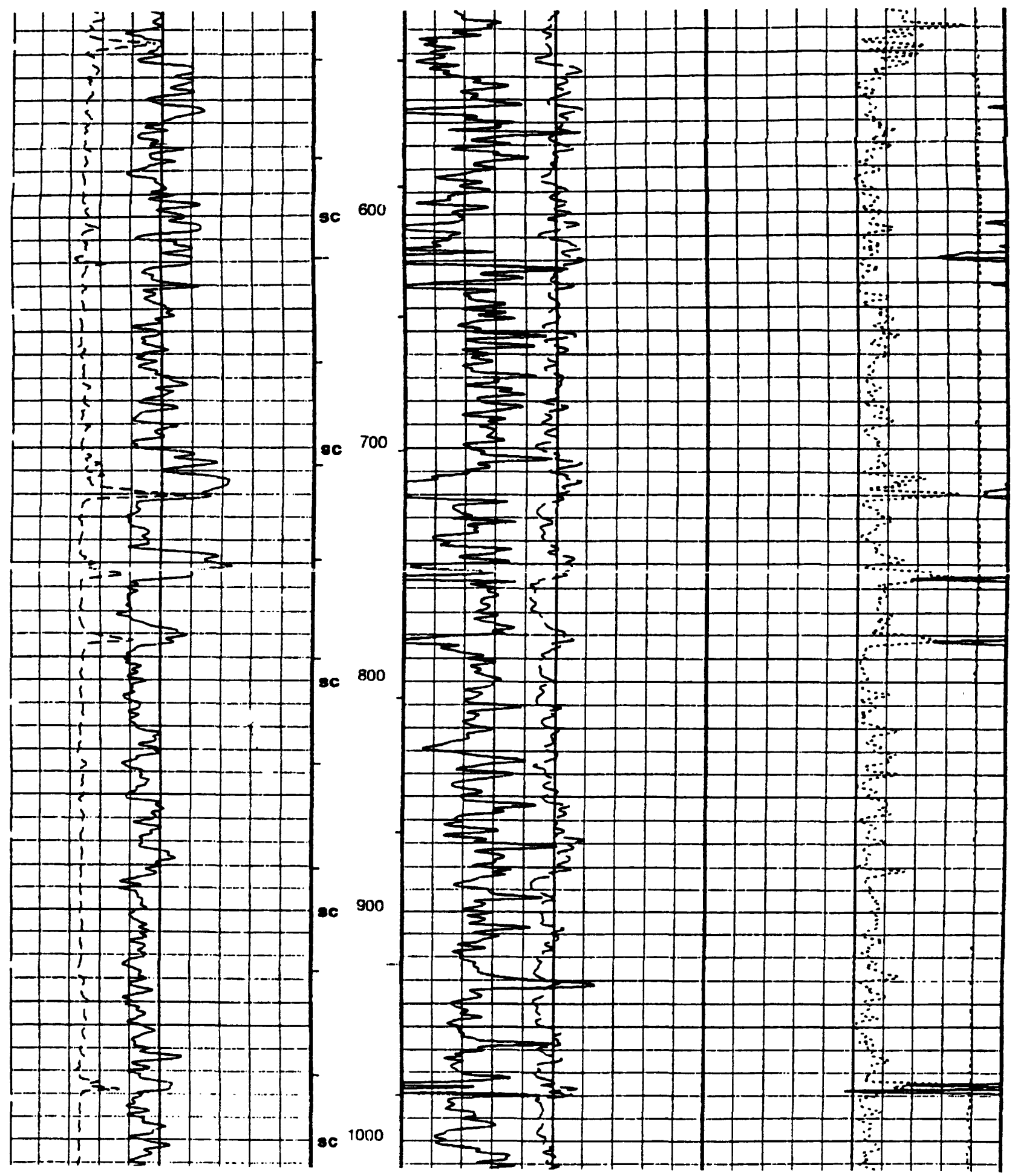



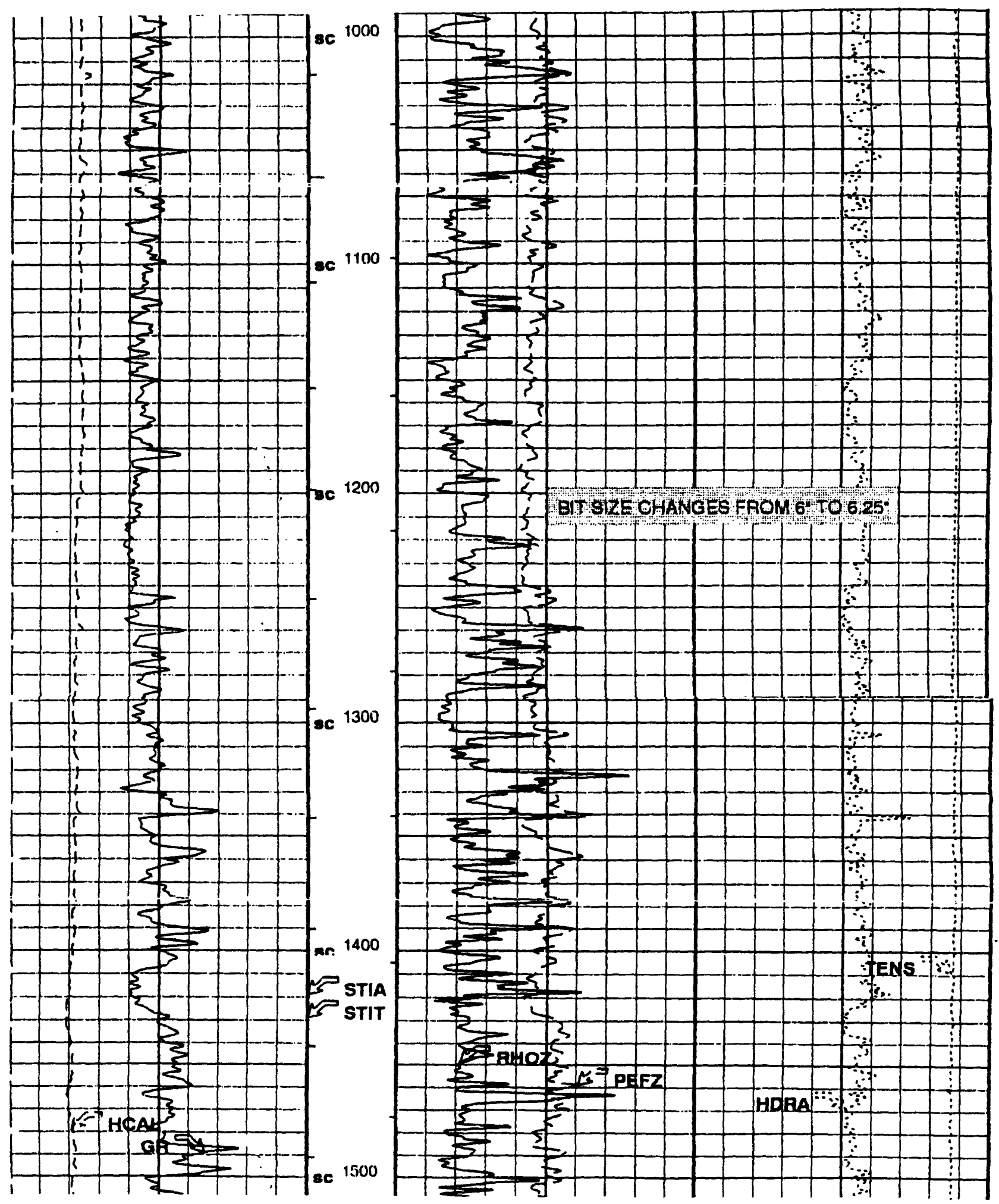


\section{Appendix D.}

PARTICLE-SIZE ANALYSES OF CHANNEL SAMPLES FROM THE 98TH STREET CORE

Analyses preformed by the

New Mexico Bureau of Mines and Mineral Resources Soils Laboratory

Socorro, New Mexico

September, 1997

In cooporation with

THE CITY OF ALBUQUERQUE 


\section{Particle Size Distribution Analysis}

\section{Mechanical Sieve Analysis:}

Prior to sieving, samples were broken-up with a mortar and pestle. A standard set of sieves were used, including numbers $4,10,20,40,60,140$, and 200 . The sample portion retained in each sieve was weighed to determine the distribution of gravel and sand size particles. Fines were collected in a pan placed at the bottom of the stacked sieves. After dry sieving, the fines (silt/clay) were set aside for later use in hydrometer analysis.

\section{Hydrometer Analysis:}

Hydrometer analysis was used to measure the silt and clay distribution of the sample that passed through the number 200 sieve. The fines collected in the pan during mechanical sieving were soaked overnight in $125 \mathrm{~mL}$ of sodium hexametaphosphate solution in order to disperse the grains. Afterwards, the suspension was placed in a blender for 10 minutes for further dispersion. Next, the suspension was diluted to $1000 \mathrm{~mL}$ with distilled water, placed in a cylinder, and the test conducted using a $152 \mathrm{H}$ hydrometer. A hydrometer correction of -3 was used to account for the impact of sodium hexametaphosphate on solution density. The following two equations were used for hydrometer analysis of grain size, $\mathbf{d}$, and percent finer than, $\mathbf{P}_{\mathbf{r}}$ :

$$
\begin{gathered}
d=\sqrt{\frac{30 N L}{980\left(G_{S}-G_{W}\right) t}}, \text {, and } \\
P_{f}=\frac{100 a R}{W_{S}},
\end{gathered}
$$

where $\mathbf{N}$ is the coefficient of viscosity for water at test temperature, $\mathbf{L}$ is hydrometer effective depth, $\mathbf{G}_{\mathbf{s}}$ is the specific gravity of the soil solids (assumed to be 2.65 ), $\mathbf{G}_{\mathbf{w}}$ is the specific gravity of water at test temperature, $\mathbf{t}$ is time in minutes, $\mathbf{a}$ is ratio of $\mathbf{G}_{\mathbf{s}}$ to $2.65, \mathbf{R}$ is the corrected hydrometer reading, and $\mathbf{W}_{\mathbf{s}}$ is the dry weight of the sample used in the hydrometer analysis.

\section{Gradation Analysis:}

Sample gradation was determined after calculating the coefficient of curvature, $\mathbf{C}_{\mathrm{C}}$, and the coefficient of uniformity, $C_{\mathrm{t}}$. Equations for both coefficients are as follows:

$$
\begin{gathered}
C_{C}=\frac{\left(D_{30}\right)^{2}}{\left(D_{10}\right)\left(D_{60}\right)} \quad, \text { and } \\
C_{U}=\frac{D_{60}}{D_{10}}, \quad,
\end{gathered}
$$


where $\mathbf{D}_{10}$ is the grain diameter at $10 \%$ passing, $\mathbf{D}_{\mathbf{3 0}}$ is the grain diameter at $30 \%$ passing, and $\mathbf{D}_{60}$ is the grain diameter at $60 \%$ passing. A sandy sample is considered well-graded if:

$$
\begin{aligned}
& 1 \leq C_{C} \leq 3 \\
& C_{U} \geq 6
\end{aligned}
$$

If either of these conditions do not hold, then the sample is said to be uniformly-graded.

Note: These samples (Units 1-21) appear to be rotary drilling cuttings. If this is the case, residual drilling mud may skew the overall results 

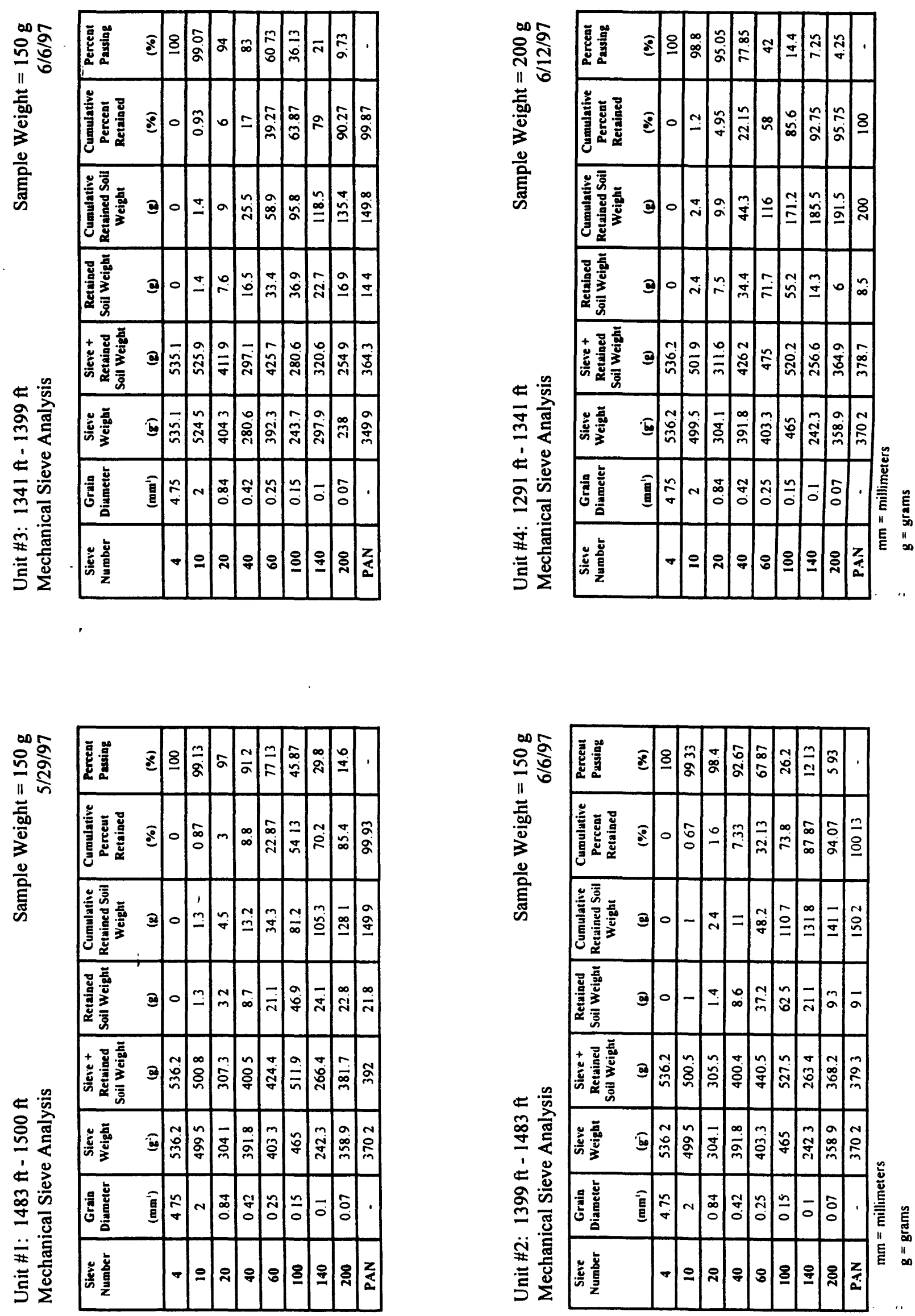

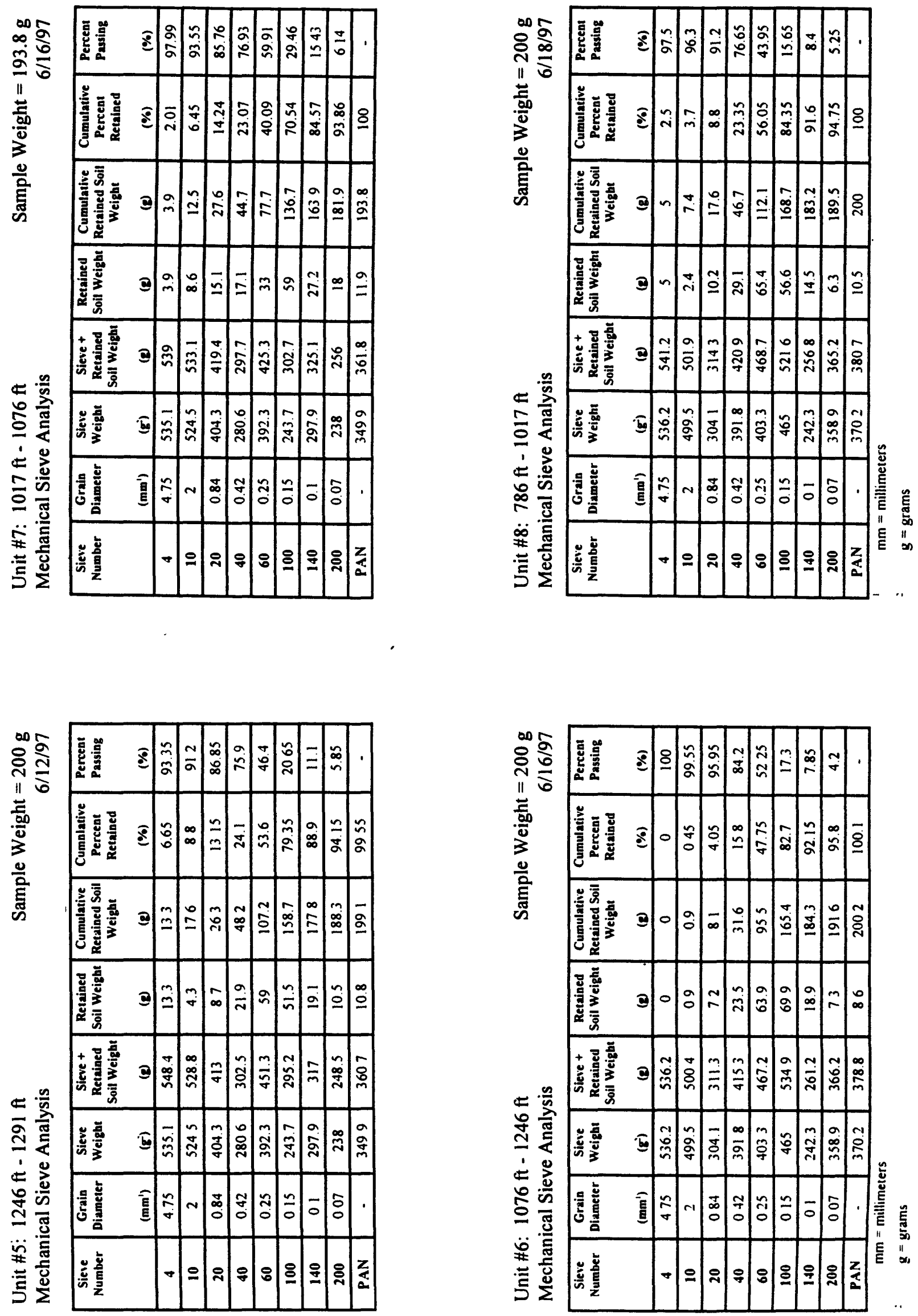

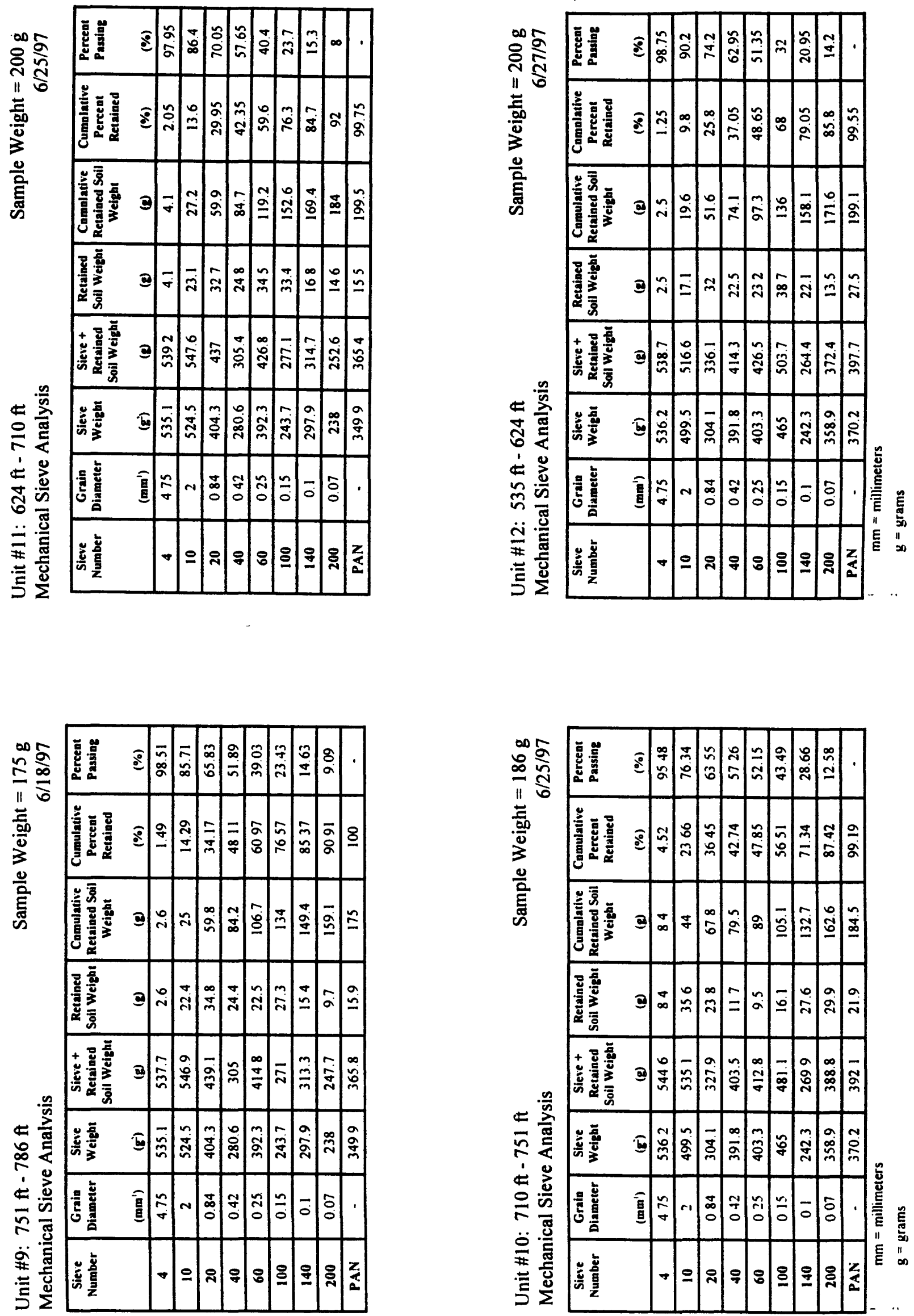

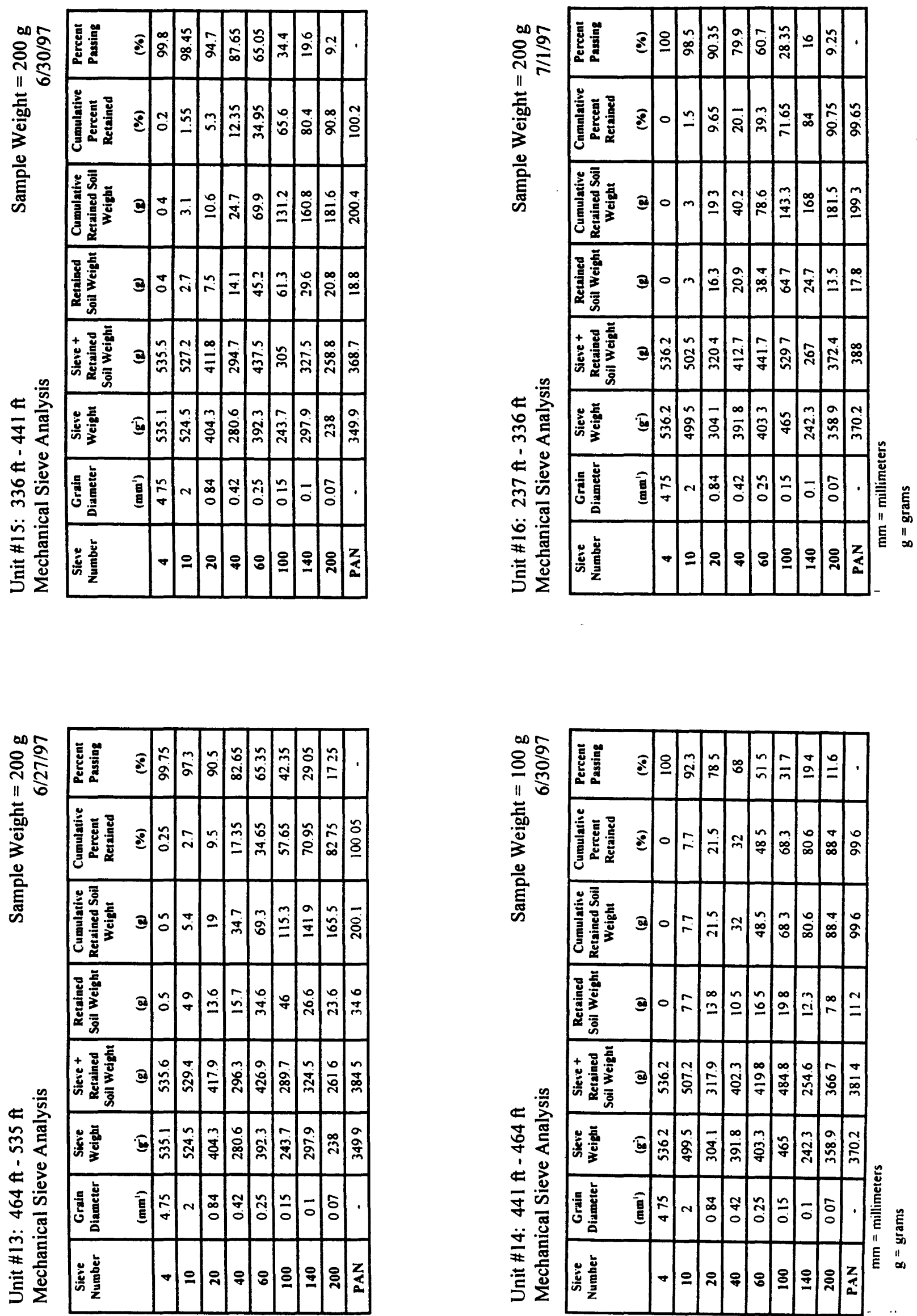

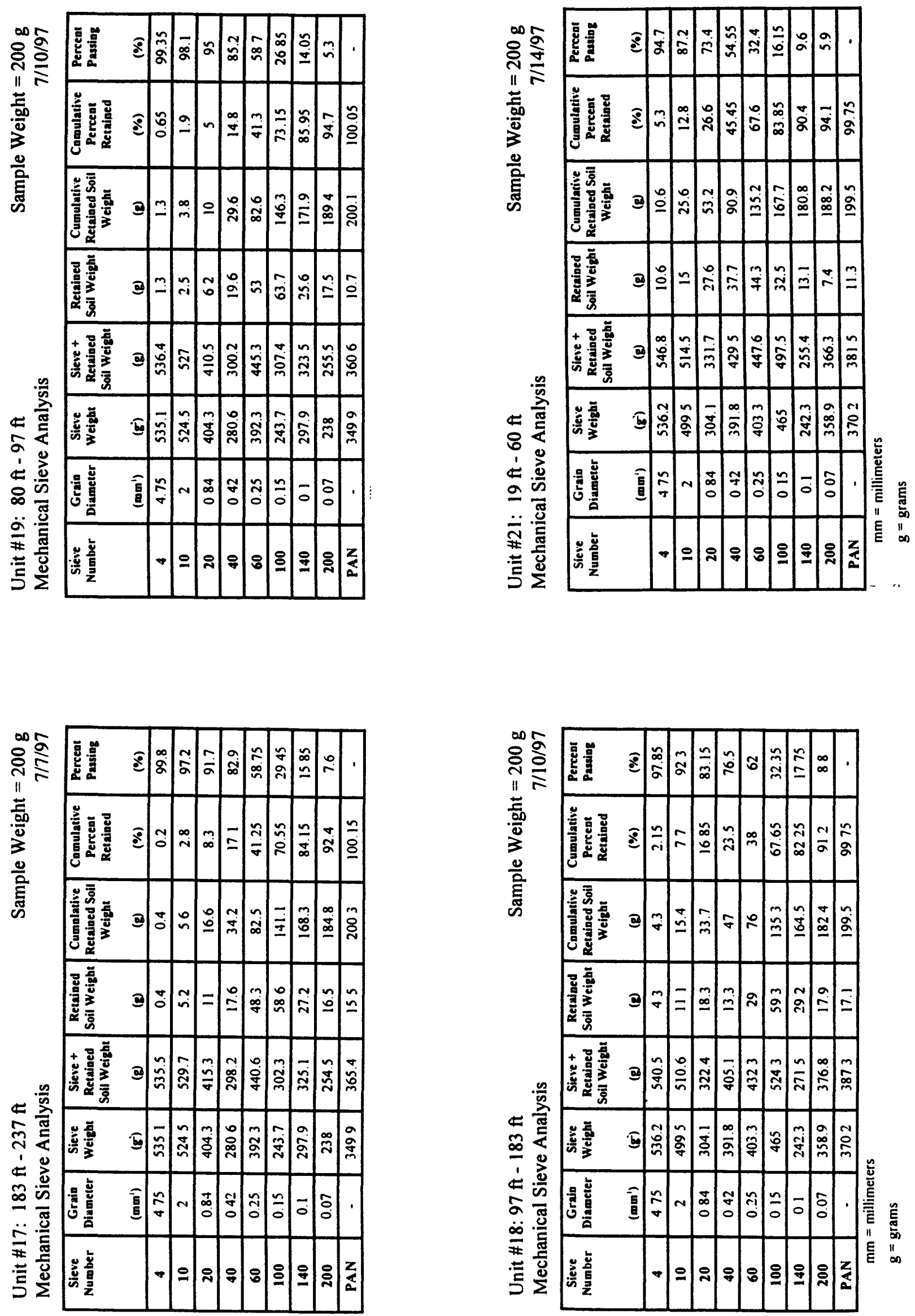


\title{
Appendix E
}

\section{HYDRAULIC CONDUCTIVITY FROM UNCONSOLIDATED-DRAINED, RECOMPACTED SANDY SAMPLES FROM THE 98TH STREET CORE}

\author{
Analyses preformed by the \\ New Mexico Bureau of Mines and Mineral Resources Soils Laboratory \\ Socorro, New Mexico \\ September, 1997 \\ In cooporation with \\ THE CITY OF ALBUQUERQUE
}




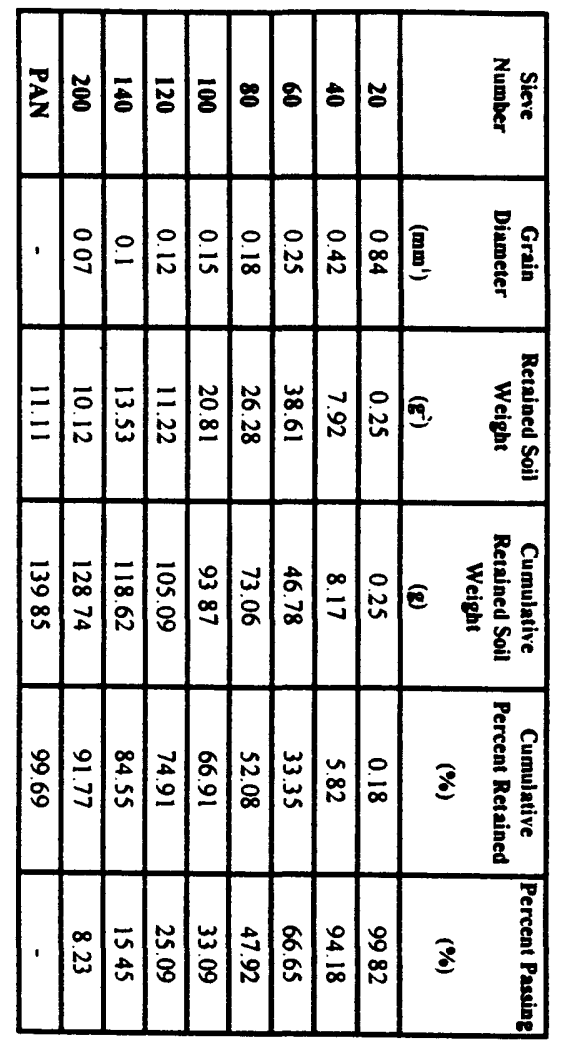

蛋

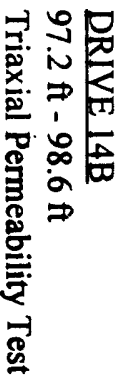

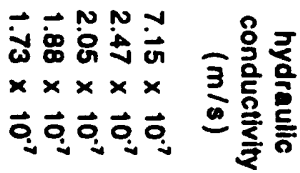

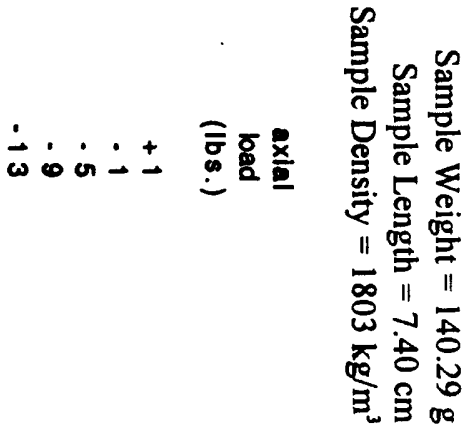

\begin{tabular}{|c|c|c|c|c|c|c|c|c|c|}
\hline $\mid \begin{array}{l}2 \\
z\end{array}$ & 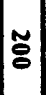 & $\overline{\mathrm{o}}$ & $\overline{\check{\sigma}}$ & $\bar{\varnothing}$ & 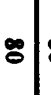 & 8 & ¿ & & 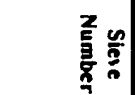 \\
\hline$\cdot$ & $\begin{array}{l}0 \\
0 \\
0\end{array}$ & $=$ & $\frac{0}{1}$ & $\frac{0}{\bar{n}}$ & $\frac{0}{\infty}$ & 哯 & $\begin{array}{lll}0 & 0 \\
\vdots & 0\end{array}$ & \begin{tabular}{l|l}
$\circ$ & \\
$\infty$
\end{tabular} & 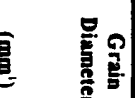 \\
\hline $\overrightarrow{0}$ & $\begin{array}{l}\tilde{\omega} \\
\bar{\omega}\end{array}$ & $\overline{\tilde{\omega}}$ & $\vec{\infty}$ & & $\begin{array}{l}\tilde{y} \\
\vec{\omega}\end{array}$ & & $\vec{t}$ & $\stackrel{0}{\stackrel{0}{u}}$ & 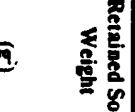 \\
\hline $\mid$ & $\mid$\begin{tabular}{c}
$\bar{N}$ \\
$\infty$ \\
$\infty$ \\
\hdashline
\end{tabular} & $\begin{array}{l}\overline{0} \\
\text { ă } \\
\vdots\end{array}$ & \begin{tabular}{l|l}
8 \\
4 \\
4
\end{tabular} & \begin{tabular}{l|l}
$N$ & \\
$\infty$ &
\end{tabular} & 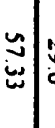 & ֻั & $\vec{\infty}$ & $\stackrel{0}{4}$ & 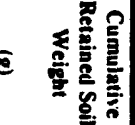 \\
\hline \begin{tabular}{l}
0 \\
0 \\
0 \\
$\infty$ \\
\hdashline
\end{tabular} & 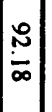 & $\begin{array}{l}\vec{n} \\
\dot{2}\end{array}$ & \begin{tabular}{l|l}
8 & \multicolumn{2}{c}{} \\
&
\end{tabular} & & & & $\begin{array}{l}\omega \\
\text { Aे }\end{array}$ & 完 & 胥 \\
\hline & : & 莣 & $\stackrel{\tilde{\sim}}{\underline{v}}$ & $\simeq$ & 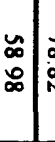 & 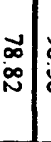 & $\begin{array}{l}2 \\
\vdots \\
\infty\end{array}$ & $\begin{array}{l}: \\
: \\
\sim \\
\sim\end{array}$ & 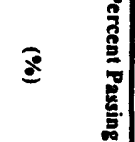 \\
\hline
\end{tabular}



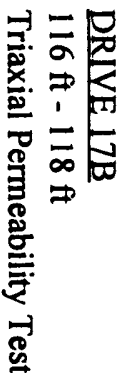

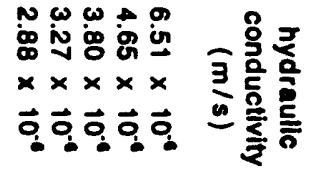

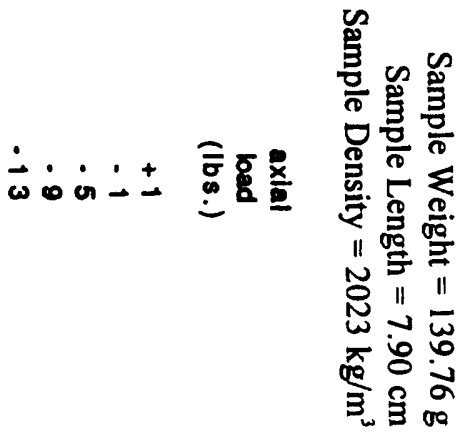



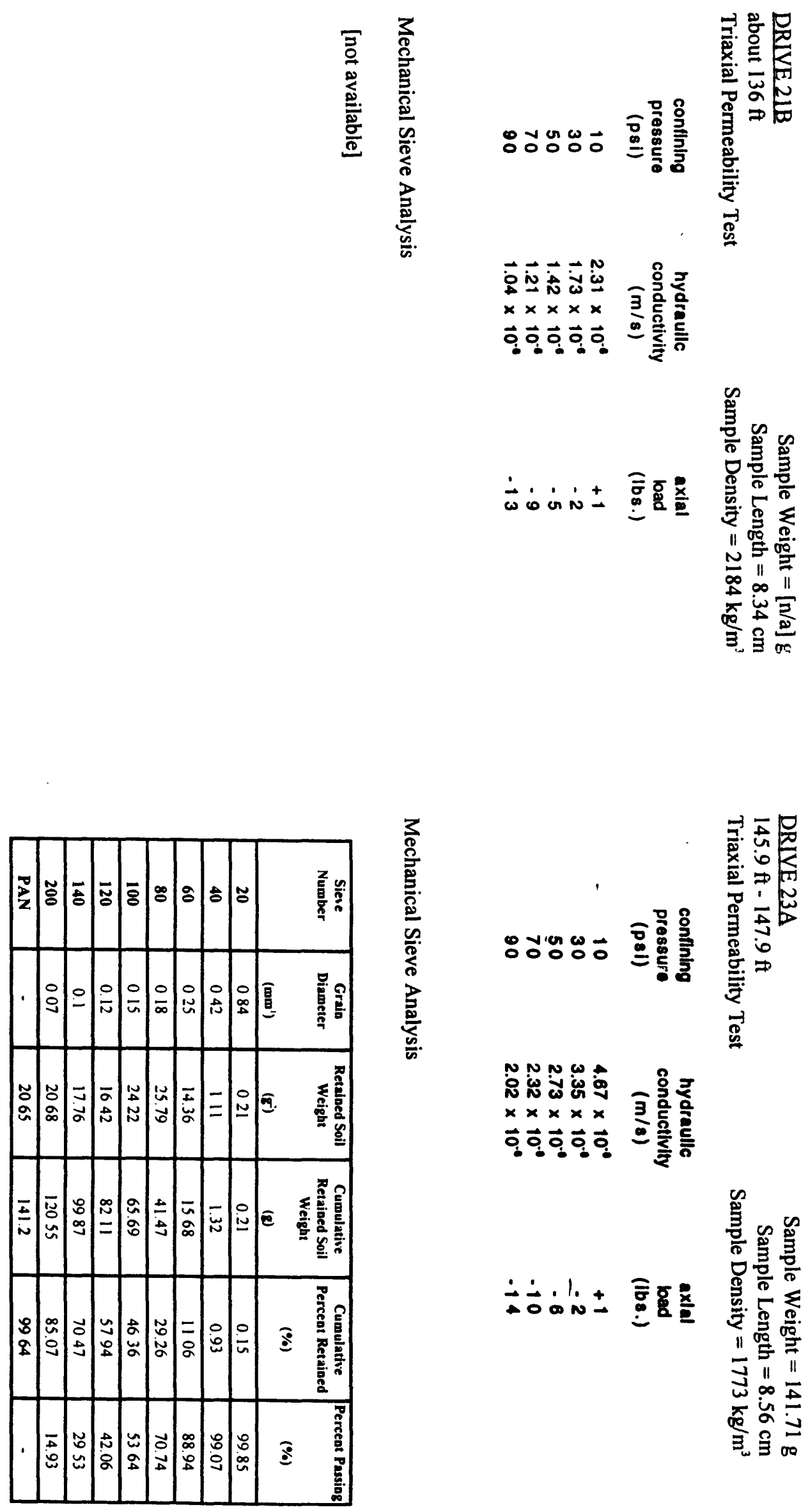

交

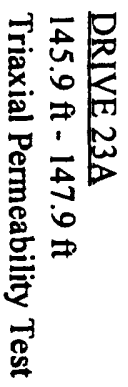

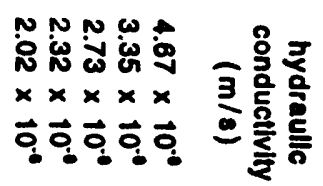

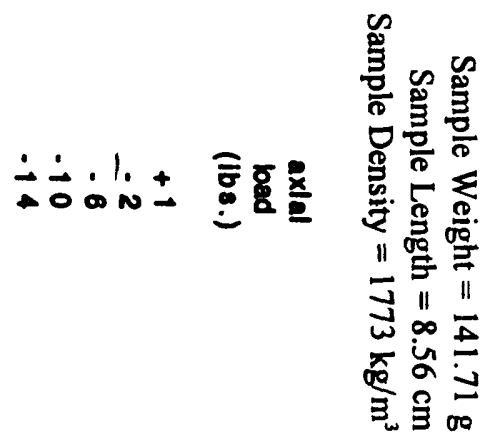



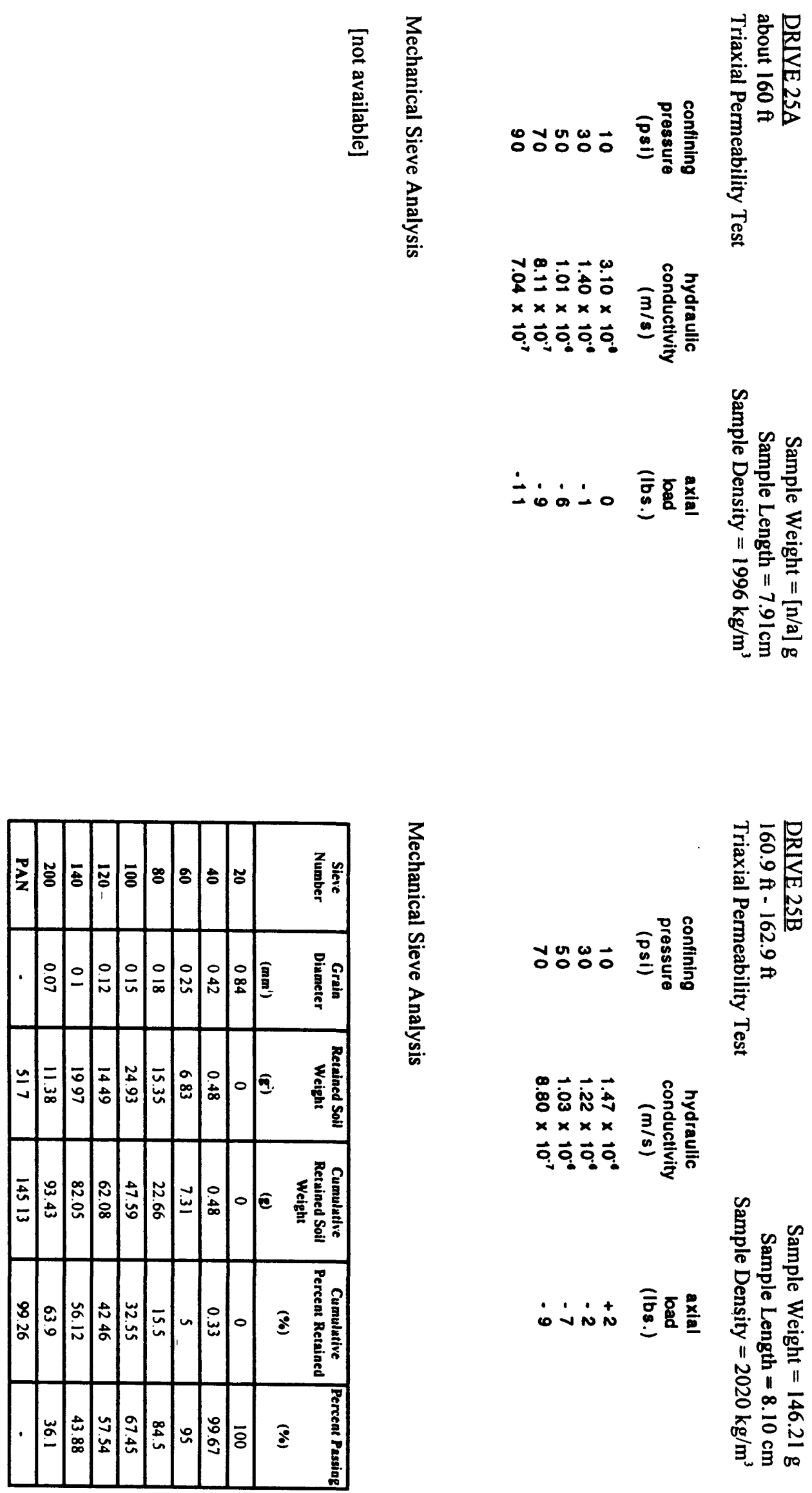

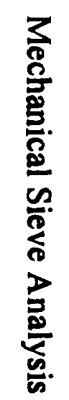

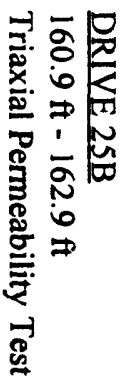

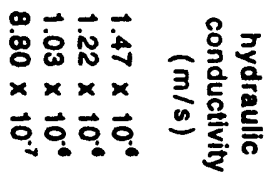

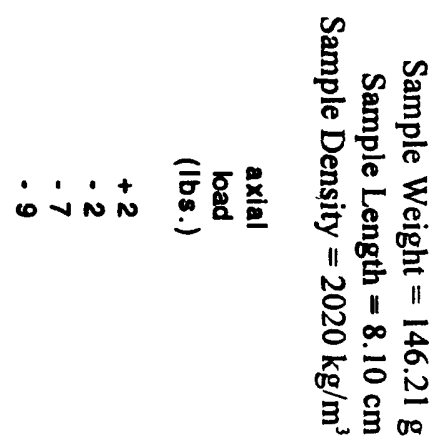




\begin{tabular}{|c|c|c|c|c|c|c|c|c|c|}
\hline$\frac{7}{2}$ & ธิ) & $\overrightarrow{0}$ & $\bar{\Xi}$ & $\overline{8}$ & 8 & के & $\Leftrightarrow$ & ๘ & 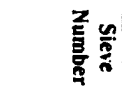 \\
\hline 1. & : & 0 & $\frac{0}{\mathrm{~s}}$ & $\frac{0}{\bar{n}}$ & $\frac{0}{\infty}$ & $\mid \begin{array}{l}0 \\
\text { U. }\end{array}$ & $\begin{array}{l}0 \\
\text { N }\end{array}$ & 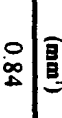 & 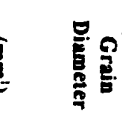 \\
\hline $\bar{\omega}_{\bar{\alpha}}^{\bar{\alpha}}$ & $\left|\begin{array}{l}\bar{a} \\
0 \\
0\end{array}\right|$ & $\left|\begin{array}{c}- \\
\infty \\
\infty \\
N\end{array}\right|$ & & 空 & $\left|\begin{array}{|l}0 \\
0 \\
0 \\
0\end{array}\right|$ & $\mid \begin{array}{l}1 \\
0 \\
0\end{array}$ & $=$ & $\begin{array}{l}0 \\
\end{array}$ & 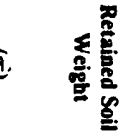 \\
\hline $\mid \begin{array}{c}\overline{\tilde{N}} \\
\hat{\Delta}\end{array}$ & $\left|\begin{array}{l}\overline{0} \\
\bar{u}\end{array}\right|$ & $\left|\begin{array}{l}\bar{N} \\
\tilde{N} \\
\alpha\end{array}\right|$ & & $\left|\begin{array}{l}\infty \\
\infty \\
\infty \\
\infty \\
\infty\end{array}\right|$ & $\left|\begin{array}{l}a \\
w \\
\hat{b}\end{array}\right|$ & $\left|\begin{array}{l}\ddot{u} \\
\ddot{\sim}\end{array}\right|$ & $\omega$ & : & (c) \\
\hline $\begin{array}{l}8 \\
\vdots \\
\alpha\end{array}$ & $\left|\begin{array}{l}0 \\
0 \\
0 \\
0\end{array}\right|$ & $\left|\begin{array}{l}0 \\
0 \\
0 \\
i\end{array}\right|$ & & $\begin{array}{l}-1 \\
0 \\
8\end{array}$ & & $\mid \begin{array}{l}N \\
i \\
N\end{array}$ & $\mid \begin{array}{c}\sim \\
\stackrel{\sim}{\sim} \\
\sim\end{array}$ & $\begin{array}{l}0 \\
\stackrel{\leftrightarrow}{\prime}\end{array}$ & ऽ。 \\
\hline 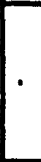 & ज. & $\frac{N}{\infty} \mid$ & 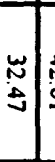 & $\begin{array}{l}\hat{A} \\
\stackrel{0}{0}\end{array}$ & $\left|\begin{array}{l}\infty \\
\tilde{\omega}\end{array}\right|$ & $\left|\begin{array}{l}1 \\
0 \\
\infty\end{array}\right|$ & $\begin{array}{l}0 \\
\dot{\omega}\end{array}$ & $\begin{array}{l}\text { : } \\
\text { a }\end{array}$ & 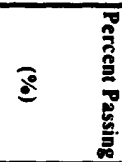 \\
\hline
\end{tabular}

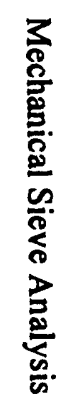

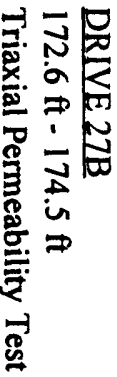

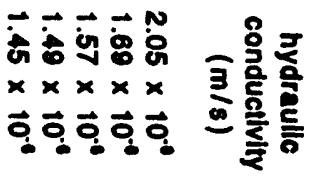
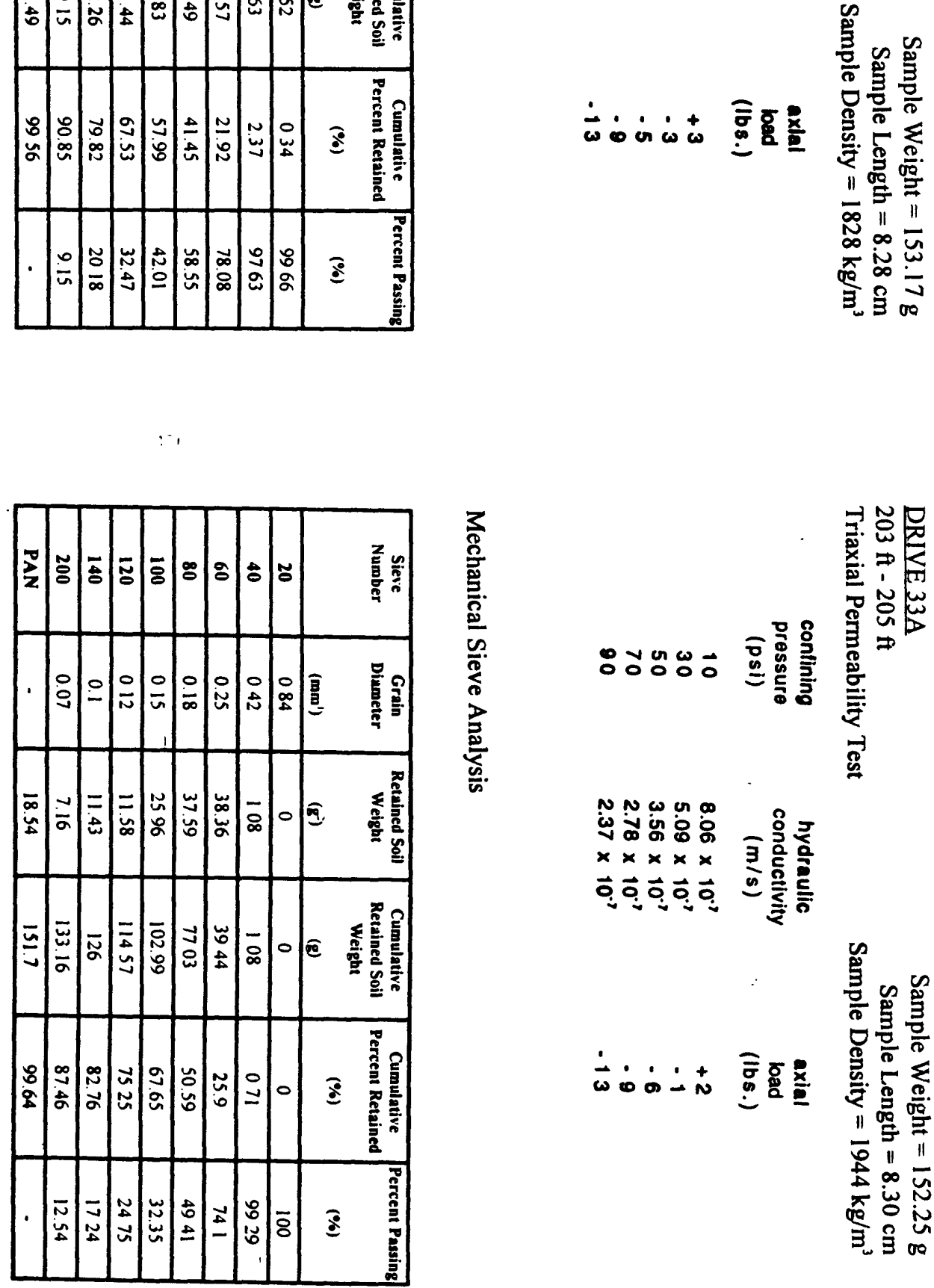

汸

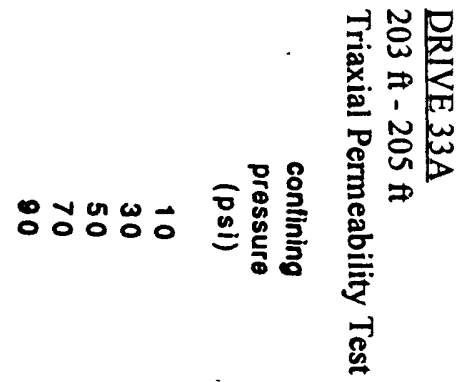

N N
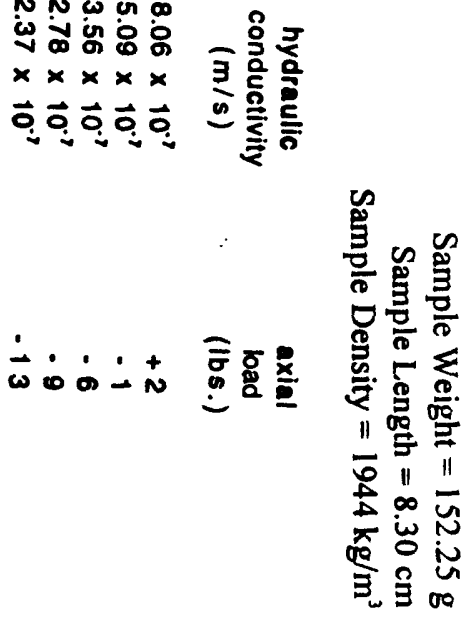

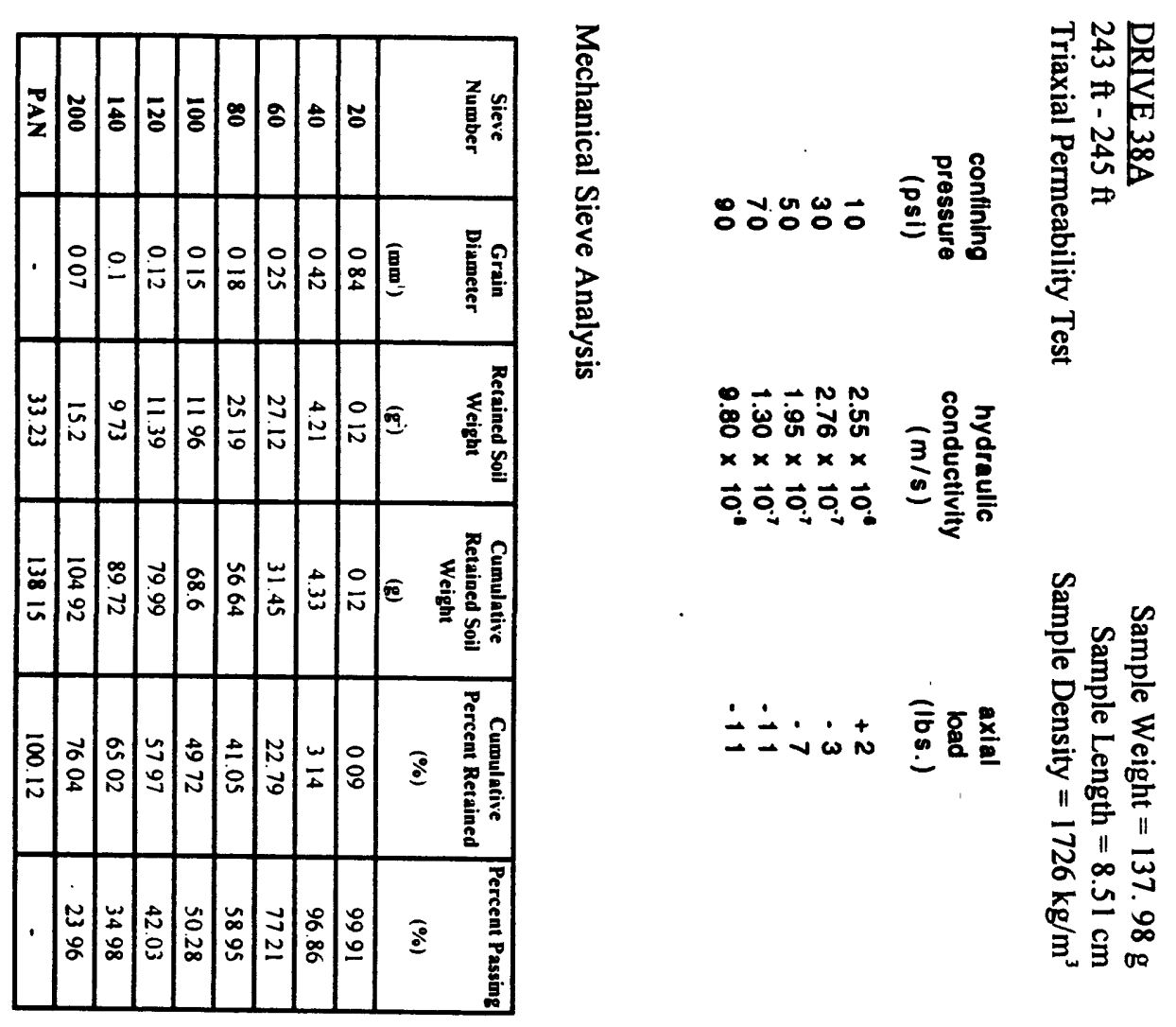

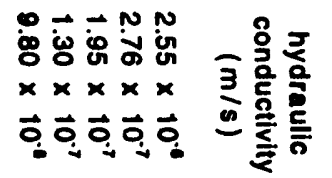
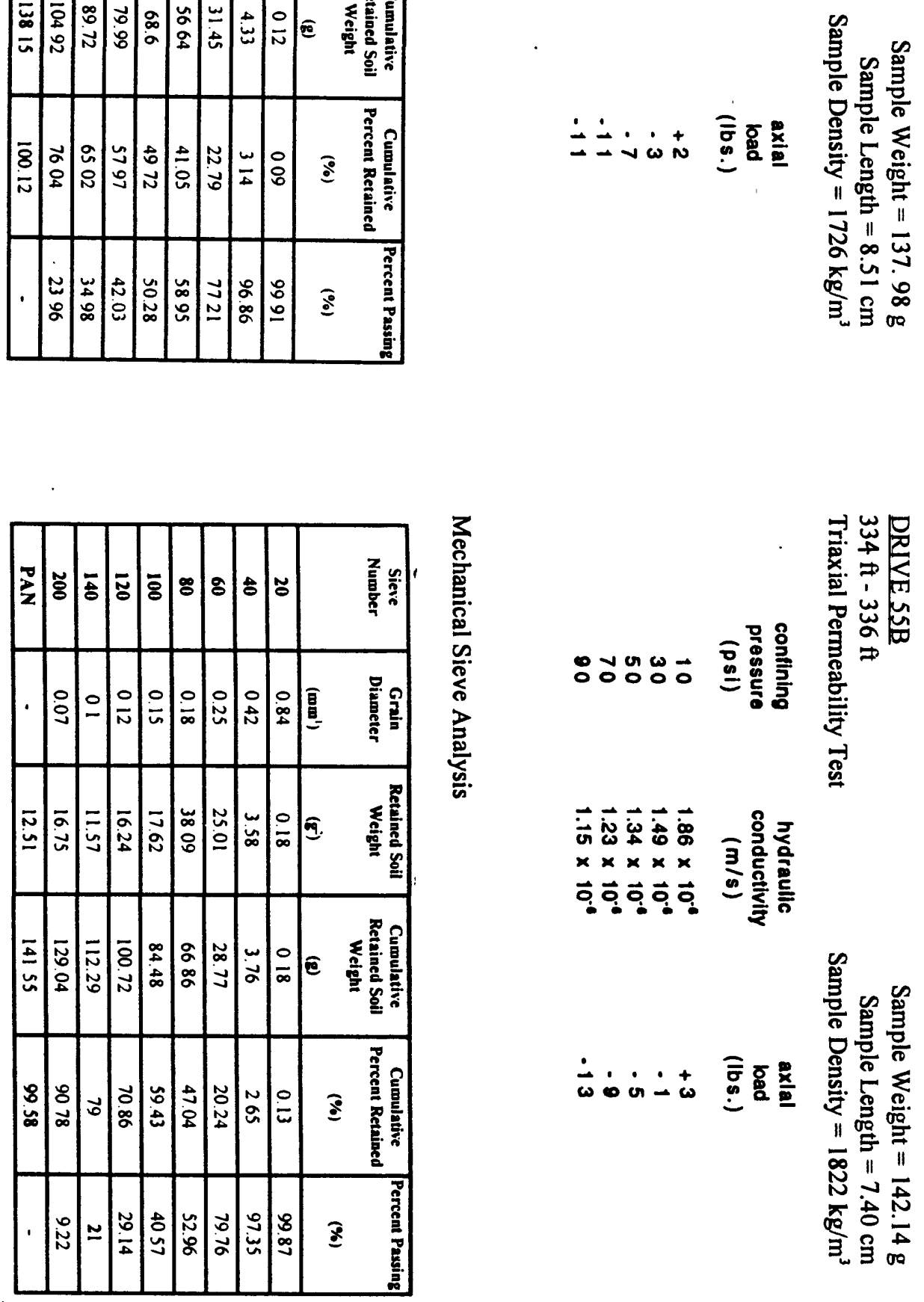

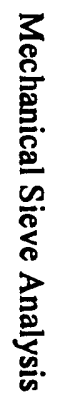

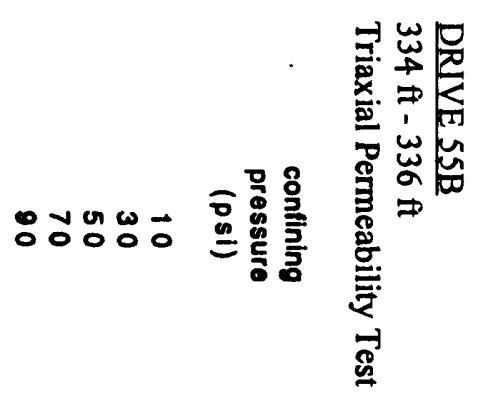

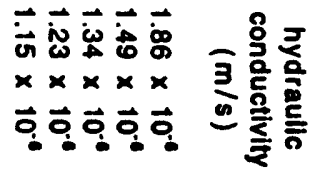

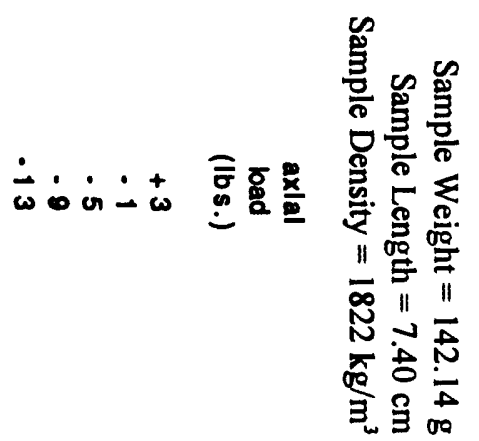




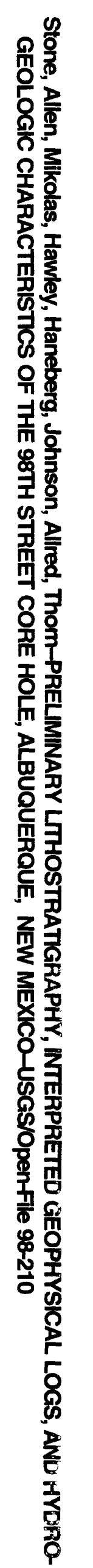

